\title{
Panama, a hot spot for Hermatomyces (Hermatomycetaceae, Pleosporales) with five new species, and a critical synopsis of the genus
}

\author{
Ondřej Koukol'1, Gregorio Delgado ${ }^{2,3}$, Tina A. Hofmann" ${ }^{4}$, and Meike Piepenbring ${ }^{3}$
}

${ }^{1}$ Department of Botany, Faculty of Science, Charles University, Benátská 2, CZ-128 01 Praha 2, Czech Republic; corresponding author e-mail: ondrej.koukol@natur.cuni.cz

${ }^{2}$ EMLab P\&K Houston, 10900 Brittmoore Park Dr. Suite G, Houston, TX 77041, USA

${ }^{3}$ Department of Mycology, Institute of Ecology, Evolution and Diversity, Goethe Universität Frankfurt, Max-von-Laue-Str. 13, 60438 Frankfurt am Main, Germany

${ }^{4}$ Centro de Investigaciones Micológicas (CIMi), Herbarium UCH, Autonomous University of Chiriquí (UNACHI), 0427, David, Chiriquí, Panama

\begin{abstract}
Five new species belonging to Hermatomyces (Hermatomycetaceae, Pleosporales) are described based on morphological investigations of specimens collected on rotten twigs and stems of various plants in Panama as well as phylogenetic analyses of sequence data of nuclear ribosomal and protein coding genes (EF1- $\alpha$, RPB2, $\beta$-TUB). The new species are described as: Hermatomyces bifurcatus, $H$. constrictus, $H$. megasporus, $H$. sphaericoides, and $H$. verrucosus spp. nov. Previously described species such as $H$. sphaericus and $H$. tucumanensis were identified among the studied specimens. The new combination, $H$. reticulatus, is made for Subicularium reticulatum based on examination of the holotype and fresh collections. Hermatomyces subiculosus, originally described from Thailand, is reduced to synonymy with $\mathrm{H}$. reticulatus; $\mathrm{H}$. tectonae is synonymized under $H$. sphaericus based on morphological and molecular evidence; and $H$. chiangmaiensis and $H$. thailandicus are considered later synonyms of $\mathrm{H}$. krabiensis and $\mathrm{H}$. indicus, respectively. The type material of Scyphostroma mirum was found to be conspecific with $H$. tucumanensis and, therefore, the generic name Hermatomyces should be conserved or protected against the older name Scyphostroma and the binomial $H$. tucumanensis against $S$. mirum. Sixteen species of Hermatomyces are recognized, their distinctive characteristics are highlighted in line drawings and a key is provided for their identification. The peculiar morphology and consistent phylogeny of new and previously known Hermatomyces species supports the recognition of the recently introduced monotypic family Hermatomycetaceae as a well delimited monophyletic taxon within the order Pleosporales.
\end{abstract}

Article info: Submitted: 22 February 2018; Accepted: 12 May 2018; Published: 22 May 2018.

\section{INTRODUCTION}

The genus Hermatomyces accommodates asexual fungi growing saprotrophicallyon dead planttissueand producing two types of multicellular conidia in nest-like, velvety sporodochia composed of melanized and sterile hyphae surrounding a fertile sporulating area (Ellis 1971). The two types of conidia usually recognized are the lenticular, muriform ones, with subhyaline to pale brown peripheral cells surrounding dark brown to black central cells, and the cylindrical ones (also referred to as paraphyses, setae or turbinate conidia), when present are composed of 1-4 columns of several (2-11) hyaline, thin-walled cells, sometimes with cell walls unevenly melanized. Speggazini (1911) first introduced the generic name, with $H$. tucumanensis as the type species, based on material collected in Argentina. In his original description he recognized only one type of conidia, the almost globose parenchymatic lenticular conidia, and interpreted the cylindrical ones as conidiophores. Later, this species was recorded from Ghana and Sierra Leone (Hughes 1953),
Cuba (Mercado 1984), Peru (Matsushima 1993), Taiwan (Chang 1995), USA (Delgado 2013), and India (Pratibha et al. 2012, Prasher \& Singh 2015) on dead leaves or wood of a wide range of plant species. Hughes (1953) also introduced the combination $H$. sphaericus for a hermatomyces-like fungus originally described as Stemphylium sphaericum with only lenticular conidia. Subsequently, four additional species were described based on morphology: $H$. dimorphus from India (Rao \& de Hoog 1986), H. amphisporus from México (Castañeda \& Heredia 2000), H. uniseriatus from Brazil (Leăo et al. 2013), and $H$. indicus from India (Prasher \& Sushma 2014).

In recent years, several species with one or two types of conidia (previously referred to as monomorphic or dimorphic, respectively) have been described from Thailand and China and further characterized using molecular sequence data. The first sequences of Hermatomyces obtained by Doilom et al. (2016) suggested a placement of the genus within Lophiotremataceae (Pleosporales). Those authors also described two further species, $H$. tectonae and $H$. thailandicus.

\section{@ 2018 International Mycological Association}

You are free to share - to copy, distribute and transmit the work, under the following conditions:

Attribution: $\quad$ You must attribute the work in the manner specified by the author or licensor (but not in any way that suggests that they endorse you or your use of the work).

Non-commercial: $\quad$ You may not use this work for commercial purposes.

No derivative works: You may not alter, transform, or build upon this work.

For any reuse or distribution, you must make clear to others the license terms of this work, which can be found at http://creativecommons.org/licenses/by-nc-nd/3.0/legalcode. Any of the above conditions can be waived if you get permission from the copyright holder. Nothing in this license impairs or restricts the author's moral rights. 
Table 1. Living cultures included in this study, their collection details and GenBank accession numbers.

\begin{tabular}{|c|c|c|c|c|c|c|c|c|c|}
\hline \multirow[t]{2}{*}{ Taxon } & \multirow{2}{*}{$\begin{array}{l}\text { Strain (herbarium } \\
\text { collection) }\end{array}$} & \multirow{2}{*}{$\begin{array}{l}\text { Country of } \\
\text { origin }\end{array}$} & \multirow[t]{2}{*}{ Host } & \multicolumn{5}{|c|}{ GenBank accession numbers } & \multirow[t]{2}{*}{ Reference } \\
\hline & & & & ITS & LSU & TEF1- $a$ & RPB2 & TUB & \\
\hline Fungal sp. & ARIZ:PS0053 & Panama & Apeiba membranacea & KU977564 & - & - & - & - & Unpublished \\
\hline Antealophiotrema brunneosporum & CBS 123095 & France & Salix sp. & LC194474 & - & - & - & - & Hashimoto et al. (2017) \\
\hline Byssolophis sphaericoides & IFRDCC 2053 & unknown & unknown & - & GU301805 & - & - & - & Zhang et al. (2009) \\
\hline H. bifurcatus & $\begin{array}{l}\text { CCF } 5899 \text { (PRM } \\
946196)\end{array}$ & Panama & unknown shrub & LS398262 & LS398262 & LS398416 & LS398343 & LS398441 & This study \\
\hline H. bifurcatus & $\begin{array}{l}\text { CCF } 5900 \text { (PMA } \\
116075)\end{array}$ & Panama & unknown shrub & LS398263 & LS398263 & LS398417 & LS398344 & LS398442 & This study \\
\hline H. chiangmaiensis & MFLUCC 16-2817 & Thailand & Pandanus sp. & - & KY559394 & - & - & - & Tibpromma et al. (2017) \\
\hline H. chromolaenae & MFLUCC 16-2818 & Thailand & Chromolaena odorata & - & KY559393 & - & - & - & Tibpromma et al. (2017) \\
\hline H. constrictus & $\begin{array}{l}\text { CCF } 5904 \text { (PMA } \\
116076, \text { PRC 4107) }\end{array}$ & Panama & Bauhinia cumanensis & LS398264 & LS398264 & LS398418 & LS398345 & LS398443 & This study \\
\hline H. indicus & MFLUCC $14-1143$ & Thailand & Tectona grandis & KU144920 & KU764692 & KU872754 & KU712488 & - & Doilom et al. (2017) \\
\hline H. indicus & MFLUCC 14-1144 & Thailand & Tectona grandis & KU144921 & KU764693 & KU872755 & KU712489 & - & Doilom et al. (2017) \\
\hline H. indicus & MFLUCC 14-1145 & Thailand & Tectona grandis & KU144922 & KU764694 & KU872756 & KU712490 & - & Doilom et al. (2017) \\
\hline H. iriomotensis & KT 2016-1 & Japan & woody plant & LC194483 & LC194367 & LC194394 & LC194449 & - & Hashimoto et al. (2017) \\
\hline H. krabiensis & MFLUCC 16-0249 & Thailand & Pandanus odorifer & KX525750 & KX525742 & KX525758 & KX525754 & - & Tibpromma et al. (2016) \\
\hline H. megasporus & $\begin{array}{l}\text { CCF } 5897 \text { (PRM } \\
946198)\end{array}$ & Panama & unknown shrub & LS398265 & - & LS398419 & LS398346 & LS398444 & This study \\
\hline H. megasporus & $\begin{array}{l}\text { CCF 5898 (PMA } \\
116077)\end{array}$ & Panama & unknown shrub & LS398266 & LS398266 & LS398420 & - & LS398445 & This study \\
\hline H. nabanheensis & KUMCC 16-0149 & P.R. China & Pandanus sp. & KY766058 & KY766059 & KY766061 & - & - & Hyde et al. (2017) \\
\hline H. pandanicolus & MFLUCC 16-0251 & Thailand & Pandanus odorifer & KX525751 & KX525743 & KX525759 & KX525755 & - & Tibpromma et al. (2016) \\
\hline H. reticulatus & $\begin{array}{l}\text { CCF } 5893 \text { (PRM } \\
\text { 946199) }\end{array}$ & Panama & unknown tree & LS398267 & LS398267 & LS398421 & LS398347 & LS398446 & This study \\
\hline H. reticulatus & $\begin{array}{l}\text { CCF } 5905 \text { (PMA } \\
116078)\end{array}$ & Panama & unknown tree & LS398268 & LS398268 & LS398422 & LS398348 & - & This study \\
\hline H. reticulatus & MFLUCC 15-0843 & Thailand & woody plant & KX259521 & KX259523 & KX259527 & KX259529 & - & Hyde et al. (2016) \\
\hline H. saikhuensis & MFLUCC 16-0266 & Thailand & Pandanus odorifer & KX525748 & KX525740 & KX525756 & KX525752 & - & Tibpromma et al. (2016) \\
\hline H. saikhuensis & MFLUCC 16-0267 & Thailand & Pandanus odorifer & KX525749 & KX525741 & KX525757 & KX525753 & - & Tibpromma et al. (2016) \\
\hline H. sphaericoides & CCF 5896 (PRC 4103) & Panama & unknown liana & LS398271 & - & LS398425 & LS398351 & LS398448 & This study \\
\hline H. sphaericoides & KZP 470 (UCH) & Panama & unknown liana & LS398274 & - & LS398428 & LS398353 & LS398451 & This study \\
\hline H. sphaericoides & $\begin{array}{l}\text { CCF } 5908 \text { (PMA } \\
116079)\end{array}$ & Panama & unknown tree & LS398273 & LS398273 & LS398427 & LS398352 & LS398450 & This study \\
\hline H. sphaericoides & $\begin{array}{l}\text { CCF } 5907 \text { (PRM } \\
946200)\end{array}$ & Panama & unknown tree & LS398272 & - & LS398426 & - & LS398449 & This study \\
\hline H. sphaericoides & CCF 5895 (PRC 4102) & Panama & Astrocaryum standleyanum & LS398270 & LS398270 & LS398424 & LS398350 & LS398447 & This study \\
\hline
\end{tabular}




\begin{tabular}{|c|c|c|c|c|c|c|c|c|c|}
\hline \multirow[t]{2}{*}{ Taxon } & \multirow{2}{*}{$\begin{array}{l}\text { Strain (herbarium } \\
\text { collection) }\end{array}$} & \multirow{2}{*}{$\begin{array}{l}\text { Country of } \\
\text { origin }\end{array}$} & \multirow[t]{2}{*}{ Host } & \multicolumn{5}{|c|}{ GenBank accession numbers } & \multirow[t]{2}{*}{ Reference } \\
\hline & & & & ITS & LSU & TEF1-a & RPB2 & TUB & \\
\hline H. sphaericus & CCF 5894 (PRC 4100) & Panama & Arecaceae & LS398277 & LS398277 & LS398429 & LS398354 & LS398452 & This study \\
\hline H. sphaericus & CCF 5901 (PRC 4104) & Panama & unknown liana & LS398278 & - & LS398430 & LS398355 & LS398453 & This study \\
\hline H. sphaericus & CCF 5902 (PRC 4106) & Panama & unknown liana & LS398279 & LS398279 & - & - & - & This study \\
\hline H. sphaericus & KZP455 (PRC 4116) & Panama & Fabaceae & LS398275 & LS398275 & - & - & - & This study \\
\hline H. sphaericus & KZP469 (PRC 4117) & Panama & unknown tree & LS398276 & - & - & - & - & This study \\
\hline H. sphaericus & $\begin{array}{l}\text { CCF } 5911 \text { (PMA } \\
116080)\end{array}$ & Panama & unknown tree & LS398281 & LS398281 & LS398431 & LS398356 & LS398454 & This study \\
\hline H. sphaericus & $\begin{array}{l}\text { CCF } 5914 \text { (PMA } \\
116081)\end{array}$ & Panama & unknown tree & LS398283 & LS398283 & LS398432 & LS398357 & LS398455 & This study \\
\hline H. sphaericus & $\begin{array}{l}\text { CCF } 5916 \text { (PRM } \\
\text { 946201) }\end{array}$ & Panama & unknown liana & LS398284 & LS398284 & LS398433 & LS398358 & LS398456 & This study \\
\hline H. sphaericus & $\begin{array}{l}\text { CCF } 5917 \text { (PMA } \\
116082)\end{array}$ & Panama & unknown tree & LS398285 & - & - & - & - & This study \\
\hline H. sphaericus & KZP 460 (PRC 4105) & Panama & unknown tree & LS398286 & LS398286 & - & - & - & This study \\
\hline H. sphaericus & KZP $462(\mathrm{UCH})$ & Panama & unknown tree & LS398287 & LS398287 & LS398434 & LS398359 & LS398457 & This study \\
\hline H. sphaericus & $\begin{array}{l}\text { CCF } 5906 \text { (PMA } \\
116085)\end{array}$ & Panama & unknown liana & LS398280 & - & - & - & - & This study \\
\hline H. sphaericus & KZP $441(\mathrm{UCH})$ & Panama & Guazuma ulmifolia & LS398282 & - & - & - & - & This study \\
\hline H. tectonae & MFLUCC $14-1140$ & Thailand & Tectona grandis & KU144917 & KU764695 & KU872757 & KU712486 & - & Doilom et al. (2017) \\
\hline H. tectonae & MFLUCC 14-1141 & Thailand & Tectona grandis & KU144918 & KU764696 & KU872758 & - & - & Doilom et al. (2017) \\
\hline H. tectonae & MFLUCC 14-1142 & Thailand & Tectona grandis & KU144919 & KU764697 & - & KU712487 & - & Doilom et al. (2017) \\
\hline H. tucumanensis & CCF $5912(\mathrm{UCH})$ & Panama & unknown tree & LS398288 & LS398288 & LS398435 & LS398360 & LS398458 & This study \\
\hline H. tucumanensis & $\begin{array}{l}\text { CCF } 5913 \text { (PMA } \\
116083)\end{array}$ & Panama & unknown tree & LS398289 & LS398289 & LS398436 & LS398361 & LS398459 & This study \\
\hline H. tucumanensis & $\begin{array}{l}\text { CCF } 5915 \text { (PRM } \\
946202)\end{array}$ & Panama & Guazuma ulmifolia & LS398290 & LS398290 & LS398437 & LS398362 & LS398460 & This study \\
\hline H. verrucosus & $\begin{array}{l}\text { CCF } 5892 \text { (PRM } \\
946203)\end{array}$ & Panama & unknown tree & LS398291 & LS398291 & LS398438 & LS398363 & LS398461 & This study \\
\hline H. verrucosus & $\begin{array}{l}\text { CCF } 5903 \text { (PMA } \\
116084)\end{array}$ & Panama & unknown liana & LS398292 & LS398292 & LS398439 & LS398364 & LS398462 & This study \\
\hline Lophiotrema neoarundinaria & KT 856 & Japan & Phyllostachys bambusoides & AB524786 & - & - & - & AB524848 & Tanaka et al. (2009) \\
\hline Lophiotrema neoarundinaria & KT 2200 & Japan & Phyllostachys bambusoides & AB524787 & - & - & - & - & Tanaka et al. (2009) \\
\hline Lophiotrema vagabundum & CBS 113975 & Sweden & Epilobium angustifolium & LC194502 & - & LC194415 & FJ795461 & - & Hashimoto et al. (2017) \\
\hline
\end{tabular}

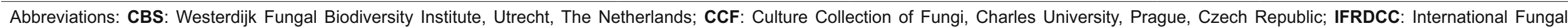

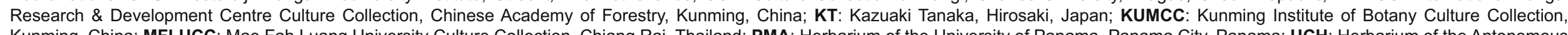

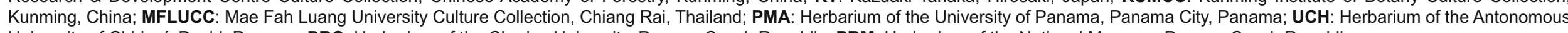
University of Chiriquí, David, Panama; PRC: Herbarium of the Charles University, Prague, Czech Republic; PRM: Herbarium of the National Museum, Prague, Czech Republic. 
Additionally, other species, notably $H$. chiangmaiensis, $H$. chromolaenae, $H$. krabiensis, $H$. pandanicola, $H$. saikhuensis, and $H$. subiculosus, have been described from single isolates obtained from rotten plant material (Hyde et al. 2016, Tibpromma et al. 2016, 2017). Hyde et al. (2016) synonymized Scyphostroma mirum (Starbäck 1899) with Subicularium reticulatum (Farr \& Goos 1989) and combined them into $H$. mirum. More recently, the family Hermatomycetaceae was validated and reintroduced to accommodate the single genus Hermatomyces and two other species, $H$. iriomotensis and $H$. nabanheensis, described from Japan and China, respectively (Hashimoto et al. 2017, Hyde et al. 2017).

Some Hermatomyces species, such as $H$. sphaericus or $H$. tucumanensis, are apparently pantropical and quite common, while others are locally restricted and known so far only from the type or very few localities. Species introduced during the pre-molecular era were described based on distinct morphological features, but in contrast the taxonomic novelties introduced in recent years seem to lack thorough phenotypic analyses and descriptions. The plant species on which they occur and the areas of origin were emphasized for all recently described Hermatomyces species together with results of molecular analyses and minute differences in morphology (Doilom et al. 2016, Tibpromma et al. 2016).

In the course of surveys of saprobic microfungi conducted in Panama, numerous collections of Hermatomyces were made on a variety of plant debris. Due to its position along the Central American isthmus, Panama is a representative region of the Neotropics that has been relatively well explored in terms of its fungal biodiversity (Piepenbring 2006, 2007) but where hermatomyces-like fungi were previously unknown. The aim of this study is to provide an in-depth overview of the species of this genus based on morphological and molecular data obtained from freshly collected material as well as herbarium specimens. Information on known distribution areas and substrates are compiled and revised in order to elucidate their importance for species delimitation.

\section{MATERIALS AND METHODS}

\section{Specimens and morphological studies}

Specimens were collected during fieldwork carried out in the provinces of Chiriquí and Bocas del Toro, western Panama, in July 2016 and 2017. Rotten twigs and stems of various plant species showing Hermatomyces colonies were recognized in the field with a hand lens ( $\times 16$ magnification) and further observed under a dissecting microscope for morphological examination and isolation into pure culture. Lenticular conidia from colonies were first picked up using a sterile needle and placed on malt extract agar (MEA) or potato carrot agar (PCA). Further transfers and cultivation were also performed on PCA and potate dextrose agar (PDA) at room temperature $\left(23-25{ }^{\circ} \mathrm{C}\right)$. To induce sporulation, selected isolates were also grown on water agar with sterile wooden toothpicks. Sometimes, sporodochia of different morphotypes were found close to each other on the same substrate. In such cases the sporodochia used for isolation in culture were marked and preparations for light microscopy were then made from these and nearby conidiomata. Conidia were mounted in water, Melzer's reagent, lactic acid or lacto-cotton blue and examined using differential interference contrast on an Olympus BX-51 (Olympus, Tokyo) with a digital camera Olympus DP72 (Olympus, Tokyo). Colonies on the natural substrates were measured under a calibrated Olympus SZ61 stereomicroscope. Microscopic measurements are reported as the mean \pm standard deviation of values resulting from 50 measurements of structures mounted in the same reagents. Measurements were analysed using one-way ANOVA with nonparametric Kruskal-Wallis test in PAST v2.07 (Hammer et al. 2001). Holotype specimens are deposited in PMA (University of Panama Herbarium, Panama) and paratypes in UCH (Autonomous University of Chiriquí Herbarium, Panama) and PRM (Herbarium of the Prague National Museum, Czech Republic). Non-type specimens were deposited in PRC (Herbarium of the Charles University, Prague, Czech Republic). Further specimens were borrowed from the US National Fungus Collection (BPI), Royal Botanic Gardens Kew (K(M)-IMI), and PRM for comparison and observation of conidial structures.

\section{SEM microscopy}

Scanning electron microscopy was performed on a JEOL6380 LV microscope (JEOL, Tokyo). Pieces of colonies (3 $\times 3 \mathrm{~mm}$ ) from the natural substrate were fixed in osmium tetroxide vapors for $2 \mathrm{w}$ at $5-10^{\circ} \mathrm{C}$ and gold-coated in BalTec SCD 050 sputter coater (Bal-Tec, Balzers, Liechtenstein). The specimens were observed with a spot size of 38-45 $\mu \mathrm{m}$ and accelerating voltage of $20-25 \mathrm{kV}$.

\section{DNA extraction, PCR amplification and sequencing}

DNA was extracted from 2-week old cultures grown on MEA using a Zymo Research Fungal/Bacterial Kit (Zymo Research, Orange, CA). Nuclear rDNA containing the ITS1$5.8 \mathrm{~S}-\mathrm{ITS} 2$ and the highly variable D1/D2 domains of the $28 \mathrm{~S}$ regions, subsequently referred here to a ITS and LSU, was amplified with primer sets ITS1F/NL4 (White et al. 1990, O'Donnell 1993). Three fragments of protein-coding markers were also amplified; elongation factor $1 \alpha$ (EF-1 $\alpha)$, RNA polymerase II second largest subunit (RPB2) and $\beta$-tubulin $(\beta-T U B)$. The EF-1 $\alpha$ fragment was amplified with primer set 983F/2218R (Rehner \& Buckley 2005), RPB2 with RPB25F/fRPB2-7cR (Liu et al. 1999), and $\beta$-TUB with T1/T22 (O'Donnell \& Cigelnik 1997). The PCR products were viewed by electrophoresis on $1 \%(\mathrm{w} / \mathrm{v})$ TAE agarose gel stained with ethidium bromide. The PCR products were purified with the Gel/PCR DNA Fragments Extraction Kit (Geneaid Biotech, Bade City, Taiwan). Both strands of the PCR fragments were sequenced with the primers used for amplification at the Sequencing Laboratory of the OMICS Core Facility, BIOCEV (Vestec, Czech Republic). The widely used 18S rDNA region (Tibpromma et al. 2016, Hashimoto et al. 2017) was not amplified because of limited variability; all available Hermatomyces sequences from GenBank were found to differ only in three indels.

\section{Taxon sampling and phylogenetic analyses}

The closest hits and sequences from Hermatomyces species were selected from previous phylogenetic studies (Doilom et 
Table 2. Characteristics of alignments of studied gene regions and the models adopted for Bayesian analyses.

\begin{tabular}{llllll}
\hline DNA region & \#sequences & \#nucleotide sites & \#parsimony informative & \#variable & Model (BIC criterion) \\
\hline \hline ITS & 47 & 467 & 102 & 135 & TIM2ef+G \\
LSU & 37 & 513 & 25 & 43 & TrNef+I \\
RPB2 & 43 & 1011 & 211 & 273 & $\operatorname{TrNef+G}$ \\
EF1- $\alpha$ & 45 & 872 & 121 & 165 & $\operatorname{TrN+I+G}$ \\
$\beta-$ TUB & 25 & 615 & 112 & 205 & TrNef+l \\
\hline
\end{tabular}

al. 2016, Hyde et al. 2016, Tibpromma et al. 2016, Hashimoto et al. 2017, Hyde et al. 2017) and used to build datasets. Details of strains and sequences used are listed in Table 1. Five separate datasets (ITS, LSU, EF1- $\alpha$, RPB2, $\beta$-TUB) were assembled and aligned using MAFFT algorithms implemented in Geneious v. 6.1 .5 (Biomatters, Auckland) and manually edited in the same software. The best-fit substitution model for each gene was determined using the Bayesian information criterion in jModeltest v. 2.1.5 (Darriba et al. 2012) and the selected models for the ITS, LSU, EF1- $\alpha$, RPB2 and $\beta$-TUB regions including number of variable and parsimony positions are summarized in Table 2. The five datasets were tested for combinability by using the partition homogeneity test (Farris et al. 1994) implemented in PAUP* v. 4.0b10 (Swofford 2002), which showed that there was significant incongruence among the datasets. Phylogenetic analyses were performed by Bayesian inference using MrBayes v. 3.2 (Ronquist et al. 2012) and Maximum likelihood (ML) running on the RAxML Web Server v. 7.7.1 (Stamatakis et al. 2008). For Bayesian analyses, two independent runs of 4-6 M generations were run sampling every 100th generation. The first $25 \%$ of samples were discarded as burn-in and the remaining trees were used to compute a $50 \%$ majority rule consensus tree with posterior probabilities (PP) as Bayesian branch support. The average standard deviation of split frequencies estimating convergence reached the level of 0.003-0.006 at the end of analyses. The GTRCAT approximation implemented in the $\mathrm{ML}$ analysis and nonparametric bootstrapping (BS) with 1000 replicates were used for branch support.

Bayesian species tree analyses were performed with *BEAST v. 2.4.8 (Bouckaert et al. 2014), which uses multilocus data to simultaneously co-estimate gene trees embedded within a species tree under a coalescent model. Although *BEAST does not require that each gene alignment contains the same number of sequences, only 44 samples represented by at least three regions were included. The mapping of each sample to the appropriate species was based on singlegene phylogenies. BEAUTi v. 2.4.8 (Bouckaert et al. 2014) was used to create the XML-formatted input files for *BEAST using the Gamma category count with shape and proportion of invariant sites obtained from jModeltest. Site models, clock models and trees were unlinked for all regions. Relaxed log normal molecular clock model with birth-death model and gamma-distributed population sizes for the species-tree prior and a piecewise linear population size model with a constant root were selected with default values used for remaining priors. The analysis was run for $50 \mathrm{M}$ generations sampling every 5000th generation. Convergence and effective sample size (EES) were assessed for each parameter using Tracer v. 1.5 (Rambaut \& Drummond 2009). Since the ESS of all parameters was above 200, the first $20 \%$ of trees were discarded as burn-in. A maximum clade credibility tree with the $95 \%$ highest probability density was produced by using TreeAnnotator version v. 2.4.8 (Bouckaert et al. 2014) and visualized in FigTree (http://tree.bio.ed.ac.uk/software/ figtree). DensiTree v. 2.4.8 (Bouckaert et al. 2014) was used to visualize the posterior distribution of the species trees.

\section{RESULTS}

Five DNA regions (ITS, LSU, EF1- $\alpha$, RPB2, $\beta$-TUB) were sequenced in 30 specimens belonging to eight species of Hermatomyces. A good congruence between morphological features and segregation of respective sequences into clades was generally found (Fig. 1). Numerous collections belonging to $H$. sphaericus with just the lenticular conidium type grouped within a well-supported clade together with sequences attributed to $H$. chromolaenae (only in the LSU tree), $H$. pandanicola (except in the EF1- $\alpha$ tree), and $H$. saikhuensis and $H$. tectonae having one or both conidium types. Two collections tentatively identified as $H$. subiculosus (CCF 5893 and CCF 5905) formed a well-supported clade together with sequence data from the type collection of this species. The remaining single conidium type collections differing in size and wall ornamentation of their lenticular conidia grouped into two distinct clades, and described here as $H$. sphaericoides and $H$. verrucosus. Three collections with both conidium types were identified as $H$. tucumanensis and together formed a well-supported clade in all phylogenies. Two collections with unusually large conidia of both types that do not differ from $\mathrm{H}$. subiculosus with just one conidium type in their rDNA sequence data but were clearly distinct based on their coding genes are described as $H$. megasporus. Four collections with both conidium types formed two distinct and unrelated clades and are described as $H$. bifurcatus and $H$. constrictus. The majority of these clades were highly supported in the consensus species tree retrieved from the Bayesian analysis of the multilocus dataset (Fig. 2), although conflicts in some clades (most distinct at $H$. bifurcatus and $H$. nabanheensis) indicated that these genes have undergone incomplete lineage sorting. 

Hermatomyces saikhuensis MFLUCC 16-0267 Hermatomyces sphaericus CCF 5894 Hermatomyces sphaericus CCF 5901 Hermatomyces sphaericus CCF 5902 Hermatomyces sphaericus CCF 5911 Hermatomyces sphaericus CCF 5914

0.94/71. Hermatomyces sphaericus CCF 5916

Hermatomyces sphaericus KZP 460

Hermatomyces sphaericus KZP 455

KU977564 Uncultured

Hermatomyces sphaericus KZP 462

- Hermatomyces sphaericus CCF 5906

0.671- Hermatomyces sphaericus KZP 441

Hermatomyces sphaericus CCF 5917

Hermatomyces tectonae MFLUCC 14-1140

Hermatomyces tectonae MFLUCC 14-1140
Hermatomyces tectonae MFLUCC 14-1141

Hermatomyces tectonae MFLUCC 14-1142

Hermatomyces bifurcatus CCF 5899

0.681- 1/99l Hermatomyces bifurcatus CCF $5900^{H}$

85/94 Hermatomyces megasporus CCF 5897

Hermatomyces megasporus CCF $5898^{H}$

1/97. Hermatomyces reticulatus CCF 5893

$0.65 / 61$
Hermatomyces reticulatus CCF 5905
Hermatomyces subiculosus MFLUCC

0.79/- Hermatomyces tucumanensis CCF 5912

0.50/54 $-10.99 / 87$ Hermatomyces tucumanensis CCF 5912

0.76- Hermatomyces tucumanensis CC F5913

0.99190 Hermatomyces nabanheensis KUMCC 160149

0.741- Hermatomyces iriomotensis KT 2016-1 ${ }^{\mathrm{H}}$

0.741- - Hermatomyces krabiensis MFLUCC 16-0249

0.99199 Hermatomyces constrictus CCF $5904^{\mathrm{H}}$

Hermatomyces verrucosus CCF 5892

$\mathrm{H}_{\text {Hermatomyces verrucosus CCF } 5903^{\mathrm{H}}}$

Hermatomyces sphaericoides CCF 5896

0.83160 Hermatomyces sphaericoides KZP 470

Hermatomyces sphaericoides CCF 5908

II $\begin{aligned} & \text { Hermatomyces sphaericoides CCF } 5907 \\ & \text { Hermatomyces sphaericoides CCF } 5895\end{aligned}$

Lophiotrema vagabundum CBS 113975

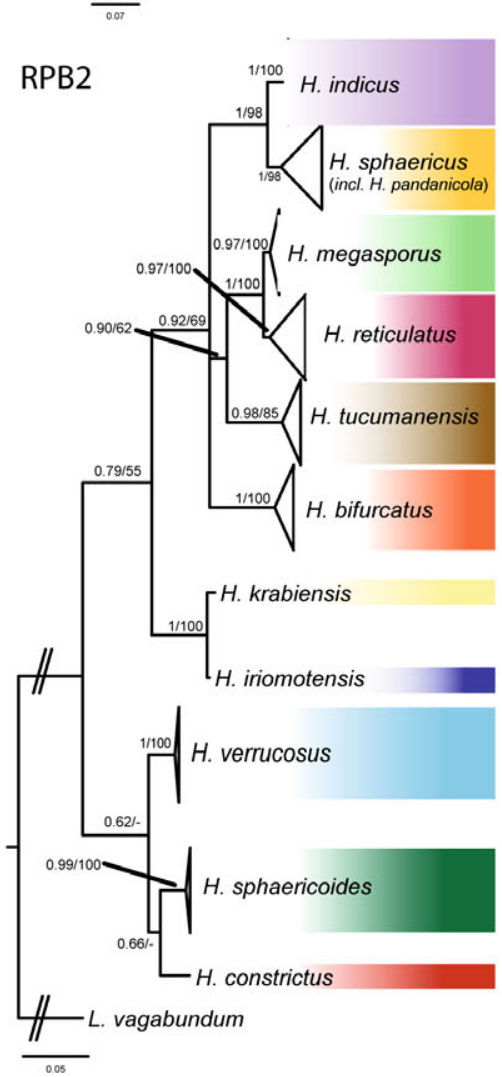

Hermatomyces thailandicus MFLUCC $14-1143^{\mathrm{H}}$ Hermatomyces thailandicus MFLUCC 14-1144 Hermatomyces thailandicus MFLUCC 14-1145 Hermatomyces chromolaenae MFLUCC $16-2818^{\mathrm{H}}$ Hermatomyces tectonae MFLUCC $14-1140^{\mathrm{H}}$ Hermatomyces tectonae MFLUCC 14-1141 Hermatomyces tectonae MFLUCC 14-1142 Hermatomyces sphaericus CCF 5894 Hermatomyces sphaericus KZP 460 Hermatomyces sphaericus KZP 462 Hermatomyces sphaericus CCF 5914 Hermatomyces sphaericus CCF 5916 Hermatomyces sphaericus CCF 5902 Hermatomyces sphaericus CCF 5911 Hermatomyces sphaericus KZP 455 Hermatomyces saikhuensis MFLUCC 16-0266 Hermatomyces saikhuensis MFLUCC 16-0267Hermatomyces pandanicola MFLUCC $16-0251^{\mathrm{H}}$ Hermatomyces bifurcatus CCF 5899 Hermatomyces bifurcatus CCF $5900^{\mathrm{H}}$

H. indicus $=H$. thailandicus

H. sphaericus $=H$. chromolaenae $=H$. saikhuensis

H. pandanicola

H. bifurcatus

H. nabanheensis

H. megasporus

H. reticulatus $=H$. subiculosus

I. verrucosus

H. sphaericoides

H. constrictus

H. iriomotensis

H. krabiensis

$=H$. chiangmaiensis

H. tucumanensis

Hermatomyces megasporus CCF $5898^{\mathrm{H}}-0$ Hermatomyces reticulatus CCF 5893 Hermatomyces reticulatus CCF 5905 Hermatomyces subiculosus MFLUCC $15-0843^{\mathrm{H}}$ Hermatomyces verrucosus CCF 5892 Hermatomyces verrucosus CCF $\left.5903^{H}\right]^{0.98 / 81}$

Hermatomyces sphaericoides CCF 5908 ${ }^{H}{ }_{1}^{1 / 89}$

Hermatomyces sphaericoides CCF 5895

Hermatomyces constrictus CCF $5904^{\mathrm{H}}$

Hermatomyces iriomotensis KT 2016-1

Hermatomyces krabiensis MFLUCC 16-0249 Hermatomyces chiangmaiensis MFLUCC $\left.16-2817^{\mathrm{H}}\right]$

Hermatomyces tucumanensis CCF 5912

Hermatomyces tucumanensis CCF $5915+1 / 99$ Hermatomyces tucumanensis CCF 5913 Byssolophis sphaerioides IFRDCC 2053
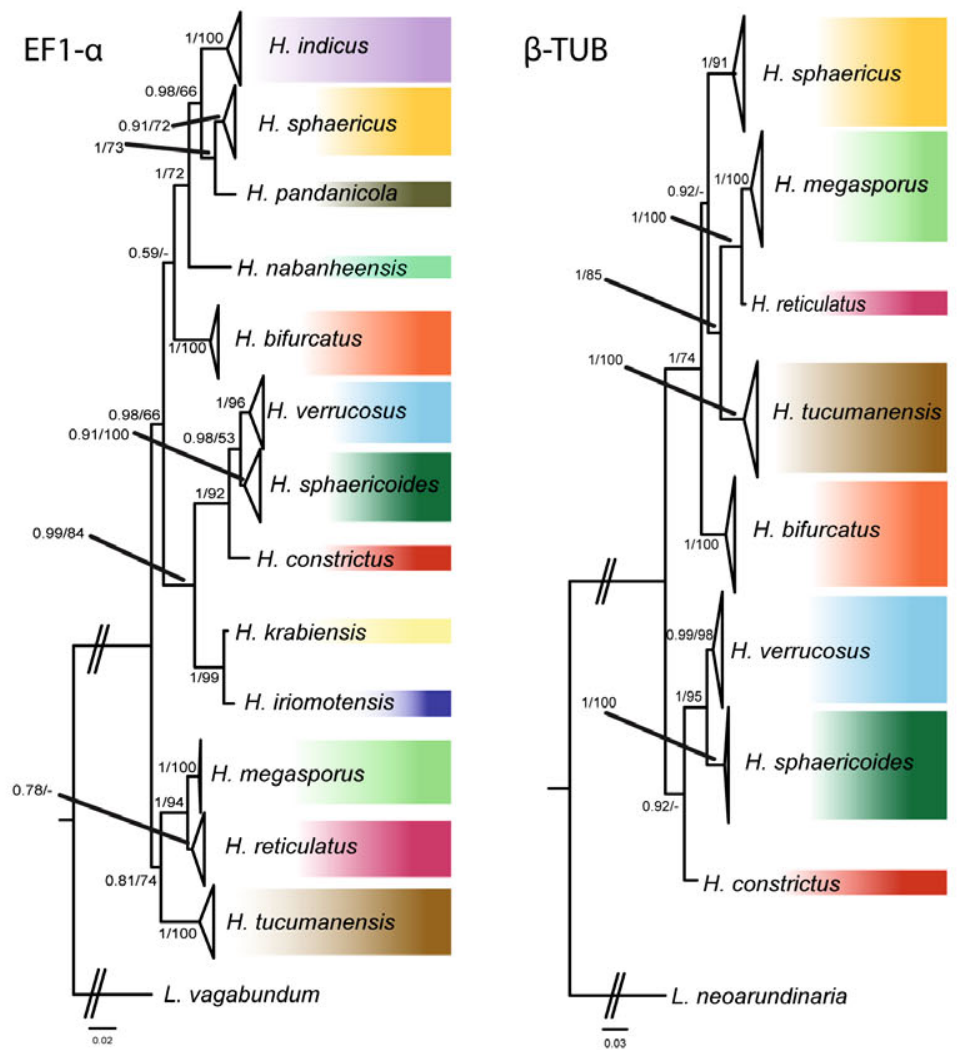

Fig. 1. Phylogenetic trees inferred from Bayesian and ML analyses of the genus Hermatomyces based on ITS, LSU, RPB2, EF1- $\alpha$ and $\beta$-TUB and including five newly described Hermatomyces taxa. Numbers above branches represent PP $>0.5$ and ML bootstrap support values BS> $>00 \%$. Ex-type living cultures are indicated by superscript letter: $\mathrm{H}-$ holotype. 
A

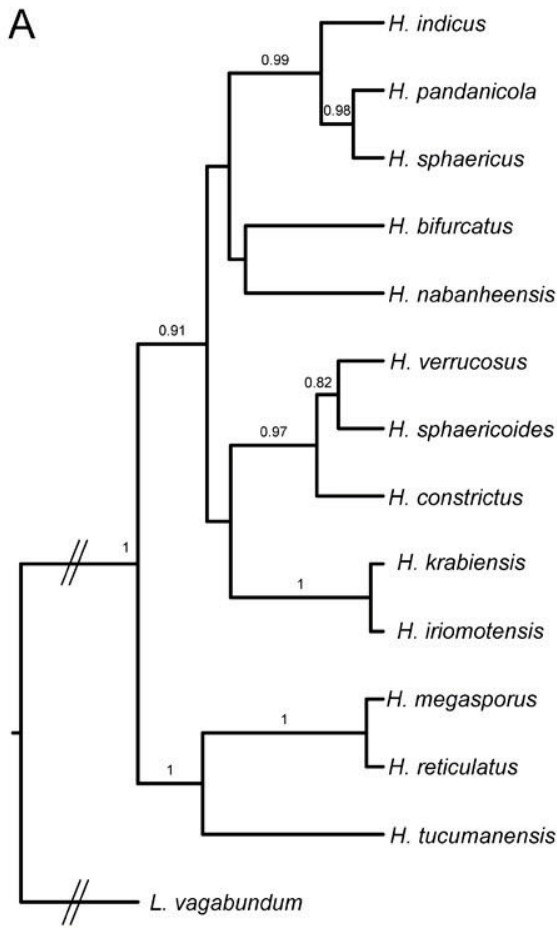

B

Fig. 2. Species trees from Bayesian analysis of combined dataset of ITS, LSU, RPB2, EF1- $\alpha$ and $\beta-T U B$. A. Consensus topology resulting from the *BEAST analysis. Numbers above branches represent $\mathrm{PP}>0.5$. B. Vizualization of 8000 trees with green lines representing the most likely topologies obtained from DensiTree.

\section{TAXONOMY}

Hermatomyces Speg., Anal. Mus. nac. B. Aires, ser. 3 13: 445 (1911).

Type species: Hermatomyces tucumanensis Speg. 1911.

\section{Classification: Hermatomycetaceae, Pleosporales, Dothideo- mycetes}

Notes: The family Hermatomycetaceae was recently reintroduced and validly published by Hashimoto et al. (2017). Although the family is currently monotypic, similarly to several other families among Pleosporales, its delimitation seems to be well justified. Liu et al. (2017) analyzed divergence times of all clades within Dothideomycetes treated as families or orders and found good support for the majority of them. In the phylogeny presented by Hashimoto et al. (2017), the Hermatomycetaceae clade rooted comparably deep to the closely related Anteagloniaceae and Lophiotremataceae suggesting similar divergence times.

\section{Hermatomyces bifurcatus Koukol \& G. Delgado, sp. nov. MycoBank MB824244}

(Figs 4, 13A, D, G, J, 16B)

Etymology: bifurcates, referring to the furcate shape of cylindrical conidia.

Diagnosis: Differs from other species of Hermatomyces with two conidium types in the cylindrical conidia with two bifurcating columns of cells, each arising from a bulbous basal cell and ending in a verrucose and pigmented apical cell.

Type: Panama: Chiriquí Province: Boquete, Bajo Mono, pipeline trail, along tourist path, $8^{\circ} 49^{\prime} 40.22^{\prime \prime} \mathrm{N}, 82^{\circ} 29^{\prime} 26.11^{\prime \prime} \mathrm{W}$, $1720 \mathrm{~m}$ a.s.I., on dry rotten twig of a shrub, $9 \mathrm{Jul} 2017, \mathrm{O}$. Koukol KZP353 (PMA 116075 - holotype; CCF 5900 - exholotype culture).

Description: Colonies on the natural substrate forming sporodochial conidiomata, superficial, scattered, more or less circular or oval, mostly non-subiculate, gray-black, consisting of an orbicular, blackish gray, flattened outer zone sometimes with a poorly developed subiculum and a black, glistening, granulose sporulating centre, 300-500 $\mu \mathrm{m}$ diam. Mycelium mostly superficial, composed of a loose or compact network of repent, branched, septate, smooth, locally thick-walled, pale brown to brown hyphae, 3-4 $\mu \mathrm{m}$ wide; subicular hyphae short, ascending, irregularly geniculate or flexuous, densely packed, anastomosing. Conidiophores micronematous or semimacronematous, mononematous, cylindrical, erect, subhyaline or pale brown, smooth or finely verruculose, up to $27 \mu \mathrm{m}$ long, 2-4 $\mu \mathrm{m}$ wide, often corresponding to conidiogenous cells. Conidiogenous cells monoblastic, integrated, terminal, determinate, subhyaline to pale brown or brown, cylindrical or slightly subulate, often arising directly on the superficial mycelium and closely packed together at the fertile centre, sphaerical, subsphaerical or ampulliform, 4-6 × 3-4 $\mu \mathrm{m}$. Conidia of two types, solitary, dry; lenticular conidia muriform, smooth, broadly ellipsoidal in front view, central 


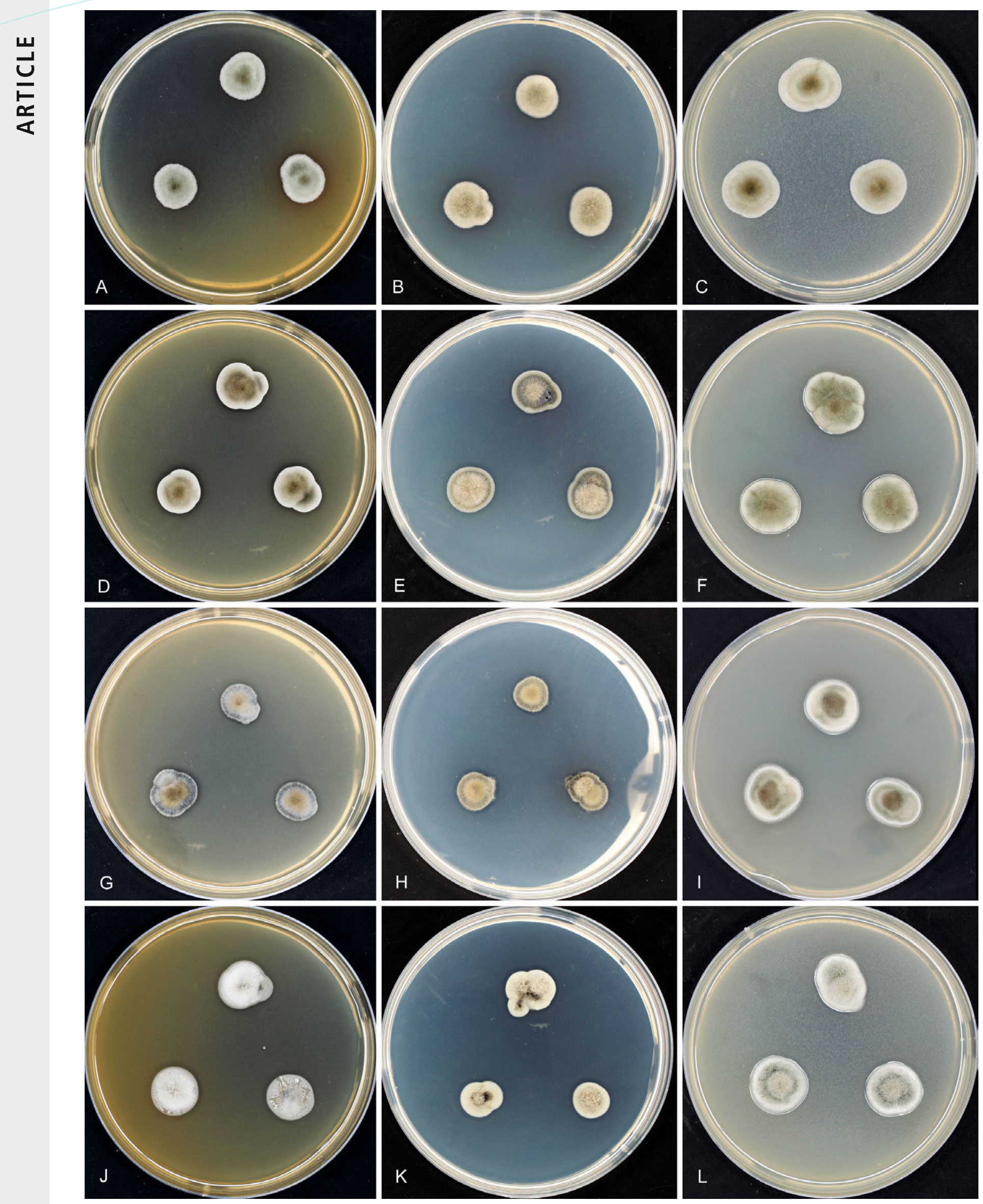

Fig. 3. Morphology of Hermatomyces colonies in culture. A-C. H. bifurcatus (CCF 5899). D-F. H. constrictus (CCF 5904). G-I. H. megasporus (CCF 5898). J-L. H. reticulatus (CCF 5893). M-O. H. sphaericoides (CCF 5908). P-R. H. sphaericus (CCF 5894). S-U. H. tucumanensis (CCF 5913). V-X. H. verrucosus (CCF 5903). All after $7 \mathrm{~d}$ growth at $25^{\circ} \mathrm{C}$ on MEA, PCA or PDA (from left to right). 


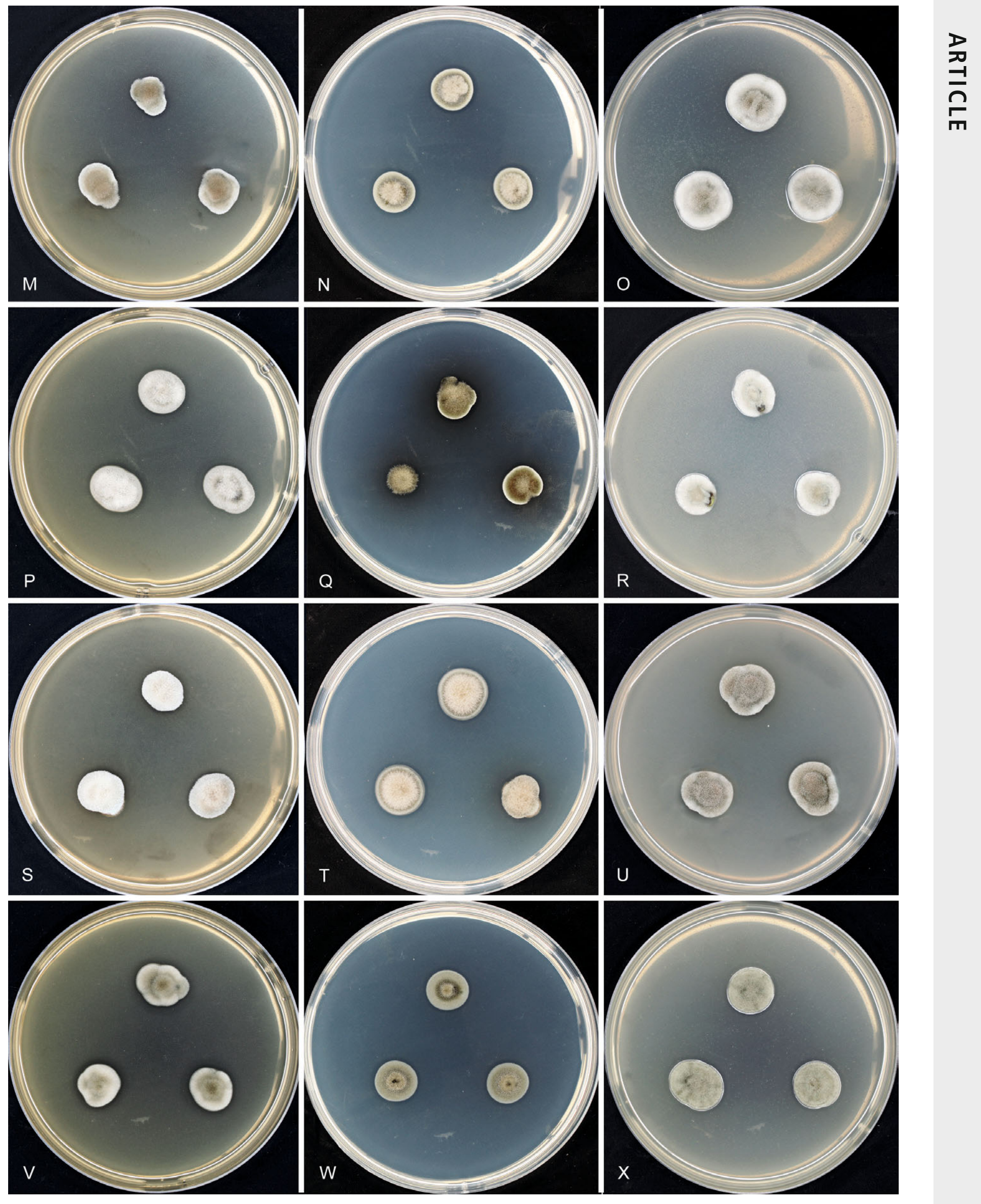

Fig. 3. (Continued). 

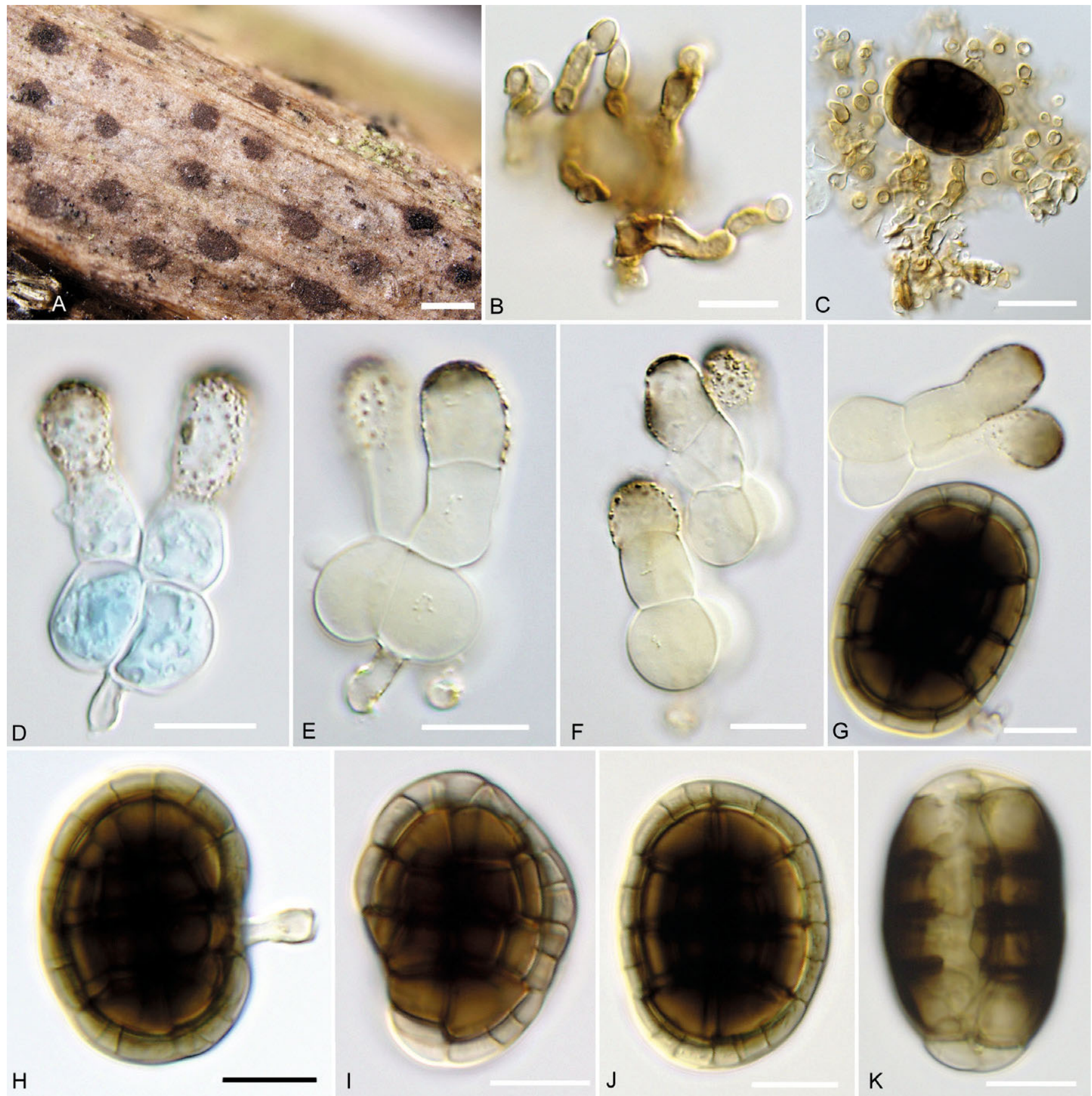

Fig. 4. Hermatomyces bifurcatus (PMA 116075 - holotype). A. Colonies on the natural substrate. B. Subicular hyphae. C. Conidiogenous cells and young lenticular conidium. D-F. Cylindrical conidia (stained with lacto-cotton blue at D). G. Cylindrical and lenticular conidium. H-K. Lenticular conidia. Bar A $=500 \mu \mathrm{m}, \mathrm{B}-\mathrm{K}=10 \mu \mathrm{m}$.

cells brown or dark brown to blackish brown, peripheral cells subhyaline to pale brown, forming a wide and distinct ring, ellipsoidal to narrowly oblong or oblong in side view where two distinct adpressed halves can be recognized, each half seen laterally as a row of 4-7 cells, end cells subhyaline to pale brown, middle cells dark brown or blackish brown, (24-) 30-36.5(-41) × (18-)21.5-26(-28) $\mu \mathrm{m}, 14-20.5 \mu \mathrm{m}$ thick, $\mathrm{L} / \mathrm{W}=1.42$; cylindrical conidia bifurcated, straight or flexuous, septate, constricted at the septa, (18-)26-33.5(-36) $\mu \mathrm{m}$ long, consisting of two columns of 3 cells, very rarely 2-celled, basal cells bulbous, globose or subglobose, smooth, hyaline, tightly appressed together, 9-14 × 13-18.5 $\mu \mathrm{m}$, middle and apical cells diverging, doliiform, cylindrical or subcylindrical, apical cells clavate or doliiform, verrucose, subhyaline or pale brown, apex rounded and dark brown or blackish brown, 7-16 × 7-12 $\mu \mathrm{m}$. Sexual morph unknown.

Cultures (Fig. 3A-C): Colonies moderately slow growing, reaching on MEA and PCA 14-16 mm diam, and on PDA 12-13 $\mathrm{mm}$ after $7 \mathrm{~d}$ at $25^{\circ} \mathrm{C}$. No sporulation observed after $4 \mathrm{~m}$ at $25^{\circ} \mathrm{C}$.

Notes: Hermatomyces bifurcatus can be distinguished from other species with two conidium types in having colonies with 
a poorly developed subiculum and cylindrical conidia with two bifurcating columns of cells each one arising from separate but tightly appressed, bulbous basal cells. The remaining cells diverge upwards and each column ends in a verrucose and pigmented apical cell. A similar ornamentation of the apical cell is present in $H$. uniseriatus (Leão et al. 2013) with lenticular conidia almost identical in size, 27-36 $\mu \mathrm{m}$ diameter and 15.5-24 $\mu \mathrm{m}$ thick, but currently without available DNA sequence data. Cylindrical conidia of $H$. uniseriatus, however, differ in consistently having only a single column of 3-4 cells and lacking a pigmented apex. Hermatomyces iriomotensis (Hashimoto et al. 2017) also shows some resemblance in the overall shape and length of its cylindrical conidia, 20.5-33 $\mu \mathrm{m}$ long and with two slightly diverging columns ending in pigmented cells. Its conidia, however, may consist of two but also of a single column of cells. They are larger in number of septa and cells, the apical ones are smooth while the basal cells are not distinctly bulbous as in $H$. bifurcatus. Phylogenetically, both species are distantly related in all analyses. Together with $H$. tucumanensis, $H$. bifurcatus has the most ellipsoidal conidia known in the genus (Fig. 18).

Additional material examined: Panama: Chiriquí Province: Boquete, Bajo Mono, pipeline trail, along tourist path, $8^{\circ} 49^{\prime} 40.22^{\prime \prime} \mathrm{N}$ $82^{\circ} 29^{\prime} 26.11^{\prime \prime W}, 1720 \mathrm{~m}$ a.s.l., on dry rotten twig of a shrub, $9 \mathrm{Jul}$. 2017, O. Koukol KZP352 (PRM 946196; CCF 5899-living culture).

\section{Hermatomyces constrictus Koukol \& G. Delgado, sp. nov. \\ MycoBank MB824245}

(Figs 5, 13B, E, H, K, 16C)

Etymology: constrictus, referring to the distinctly constricted septa of the two-celled cylindrical conidia.

Diagnosis: Differs from other species of Hermatomyces with two conidium types in the presence of two-celled cylindrical conidia that are distinctly constricted at the central or eccentric septum.

Type: Panama: Chiriquí Province: west of Los Algarrobos, path through pastures along Majagua river, $8^{\circ} 29^{\prime} 47.82^{\prime \prime} \mathrm{N}$, $82^{\circ} 26^{\prime} 19.721^{\prime \prime} \mathrm{W}, 110 \mathrm{~m}$ a.s.I., on rotten stem of Bauhinia cumanensis (Fabaceae), 14 Jul. 2017, O. Koukol KZP408 (PMA 116076 - holotype; CCF 5904 - ex-type living culture; PRC 4107 - isotype).

Description: Colonies on the natural substrate forming sporodochial, subiculate conidiomata, superficial, scattered, circular or oval, rarely confluent, brown-black, consisting of a velvety, dense, thick, annular, brown sterile mycelial outer zone enclosing a whitish black, glistening, abundantly sporulating centre, circular or oval, with the cylindrical conidia distinct among the lenticular ones, 300-500 $\mu \mathrm{m}$ diam. Mycelium superficial, composed of a compact network of repent, branched, septate, smooth or finely verruculose, pale brown to brown hyphae, 2-4 $\mu \mathrm{m}$ wide; subicular hyphae branched, septate, verrucose to strongly verrucose, locally verruculose or finely verruculose, pale brown to brown, erect, flexuous, undulate or irregularly geniculate, ascending, branching and rarely anastomosing to form a moderately dense network. Conidiophores micronematous, mononematous, cylindrical, hyaline, smooth, up to $21 \times 1.5-3 \mu \mathrm{m}$, often corresponding to conidiogenous cells. Conidiogenous cells monoblastic, integrated, terminal, determinate, often arising directly on the superficial mycelium and closely packed together at the fertile centre, sphaerical, subsphaerical or ampulliform, pale brown to brown, smooth, $4-7 \times 3.5-5 \mu \mathrm{m}$. Conidia of two types, solitary, dry; lenticular conidia muriform, smooth, disc-shaped, broadly ellipsoidal or rarely subglobose in front view, central cells brown to blackish brown or black, peripheral cells hyaline to subhyaline, forming a wide and distinct ring, slightly constricted at the septa or not, ellipsoidal in side view where two distinct adpressed halves can be recognized, each half seen laterally as a row of 6-7 cells, end cells subhyaline, middle cells blackish brown to black, (22-)25.5-29.5(-32) × 19-23.5(-27.5) $\mu \mathrm{m}$, 14.5-19 $\mu \mathrm{m}$ thick, L/W = 1.29; cylindrical conidia 2-celled, symmetrical or asymmetrical, the upper cell smaller with a central or eccentric septum, distinctly constricted at the septum, guttulate, smooth, straight or flexuous, 37-57 $\mu \mathrm{m}$ long, upper and lower cells long ellipsoidal, ellipsoidal, long ovoid, obclavate, obpyriform or sometimes broadly ovoid, often curved, lower cells (20-)24-30.5(-37) × 12-17 $\mu \mathrm{m}$, upper cells $(16-) 20-26(-30) \times 8-14 \mu \mathrm{m}$, apex more or less rounded or slightly flattened, often slightly attenuated and dark brown or black. Sexual morph unknown.

Cultures (Fig. 3D-F): Colonies moderately slow growing reaching on MEA 12-13 $\mathrm{mm}$ diam, on PCA 14-16 mm, and on PDA $14-16 \mathrm{~mm}$ after $7 \mathrm{~d}$ at $25^{\circ} \mathrm{C}$. No sporulation observed after $4 \mathrm{~m}$ at $25^{\circ} \mathrm{C}$.

Notes: Hermatomyces constrictus is unique among the species with two conidium types in having two-celled cylindrical conidia distinctly constricted at the central or eccentric septum. Hughes (1953) described and depicted similarly shaped cylindrical conidia from K(M)-IMI 39940(e) collected in Ghana that were later redrawn by Ellis (1971). They called them "paraphyses" or "setae" and wrongly considered them to belong to $H$. tucumanensis. That specimen is tentatively identified here as $H$. cf. constrictus but differs in having two but also three-celled conidia, slightly or not constricted at the septa and smaller in size reaching up to $45 \mu \mathrm{m}$ in length. The upper cells are cylindrical or subcylindrical to broadly ellipsoidal and often widened at the melanized, slightly rounded apex or dumbbell-shaped to use Ellis's words. This is in contrast to $H$. constrictus where the upper cells are often attenuated at the apex. Therefore, the specimen from Ghana most probably represents a different species.

Additional material examined: Panama: Chiriquí Province: Boquete, Bajo Mono, pipe line trail, 8`49‘40.22“'N 82²9'26.11“'W, 1720 m a.s.l., on dry rotten twig of unknown tree, 9 Jul. 2017, O. Koukol KZP343 (PRC 4097); Los Algarrobos, path to Majagua river, $8^{\circ} 29^{\prime} 13.86^{\prime \prime} \mathrm{N}$ $82^{\circ} 26$ '2.881“W, $105 \mathrm{~m}$ a.s.I., on rotten twig of liana, 8 Jul. 2017, O. Koukol KZP328 (PRM 946197). 

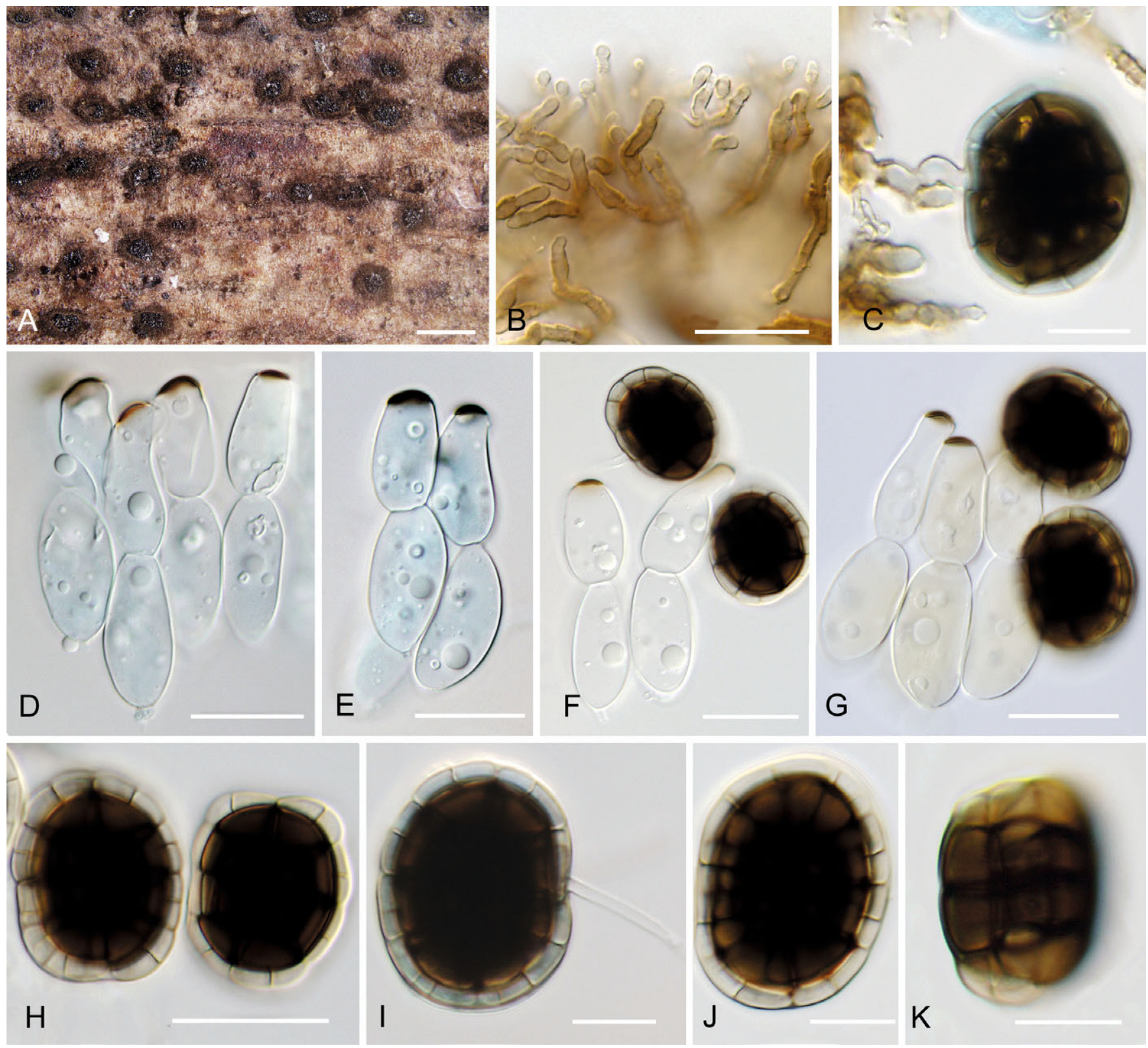

Fig. 5. Hermatomyces constrictus (PMA 116076 - holotype). A. Colonies on the natural substrate. B. Subicular hyphae. C. Young lenticular conidium attached to conidiophore (stained with lacto-cotton blue). D-E. Cylindrical conidia (stained with lacto-cotton blue). F-G. Cylindrical and lenticular conidia. H, J-K. Lenticular conidia. I. Mature lenticular conidium attached to conidiophore (stained with lacto-cotton blue). Bar A $=500 \mu \mathrm{m}, \mathrm{B}-\mathrm{G}, \mathrm{I}-\mathrm{K}=10 \mu \mathrm{m}, \mathrm{H}=20 \mu \mathrm{m}$.

Hermatomyces megasporus Koukol \& G. Delgado, sp. nov.

MycoBank MB824246

(Figs 6, 13C, F, I, L, 16H)

Etymology: megaspores, referring to the largest cylindrical conidia known in Hermatomyces.

Diagnosis: Distinguished from other species of Hermatomyces by the larger size of the conidia and from the morphologically close $H$. dimorphus in having cylindrical conidia consisting of two columns each of (5-)6-7(-10) swollen cells, appressed together but sometimes separated or rarely diverging, with apical and subapical cells laterally or apically pigmented and sometimes forming short, lateral columns around the middle or basal portions of the conidia.

Type: Panama: Chiriqui Province: Boquete, Bajo Mono, pipe line trail, close to the waterfall, $8^{\circ} 49^{\prime} 34.90^{\prime \prime} \mathrm{N}, 82^{\circ} 29^{\prime} 54.46^{\prime \prime} \mathrm{W}$, $1840 \mathrm{~m}$ a.s.I., on dry rotten twig of unknown shrub, $9 \mathrm{Jul}$. 2017, O. Koukol KZP351 (PMA 116077 - holotype; CCF 5898 - ex-holotype living culture).

Description: Colonies on the natural substrate forming sporodochial, subiculate conidiomata, superficial, scattered when young, crowded and confluent when older, more or less circular, oval or lobed, dark gray-black, consisting of a well-developed, velvety, dense, thick, annular, dark gray, 

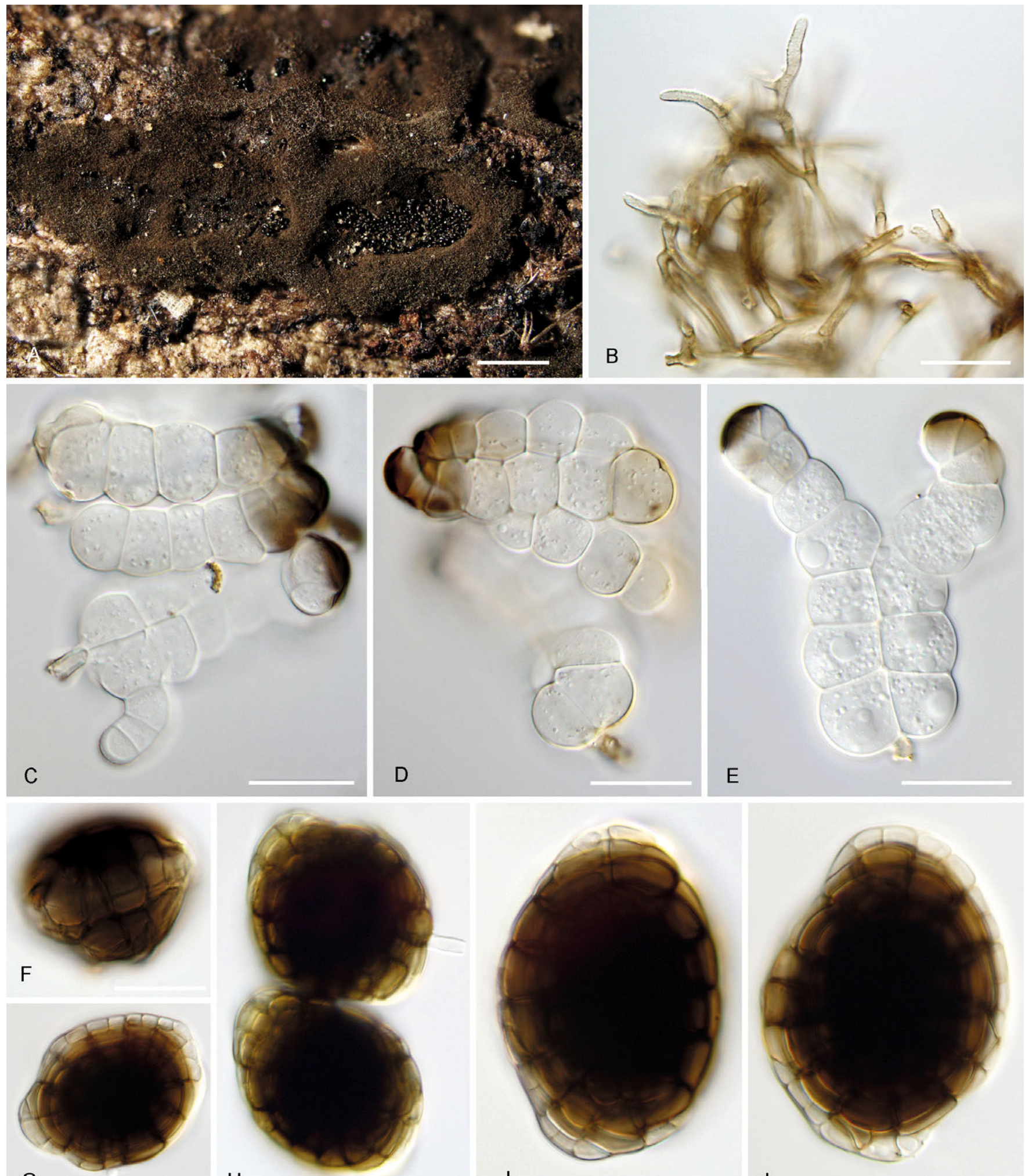

G

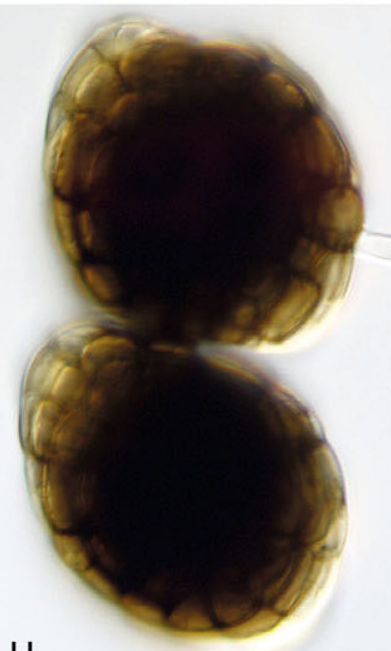

$\mathrm{H}$
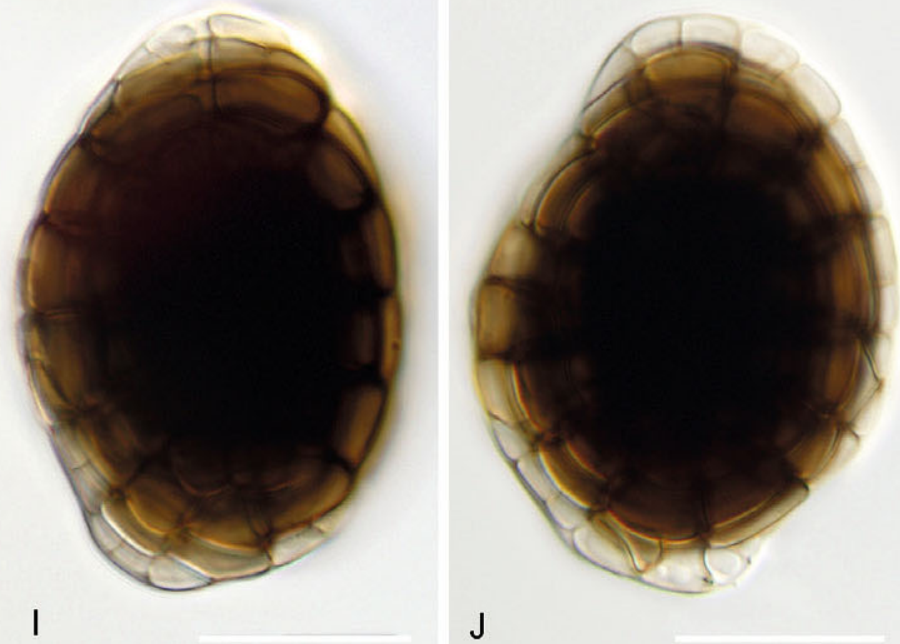

Fig. 6. Hermatomyces megasporus (PMA 116077 - holotype). A. Colonies on the natural substrate showing well-developed subiculum. B. Subicular hyphae. C-E. Cylindrical conidia. F-J. Lenticular conidia. Bar A $=500 \mu \mathrm{m}, \mathrm{B}-\mathrm{J}=20 \mu \mathrm{m}$.

sterile mycelial outer zone enclosing a black or whitish black, glistening, granulose sporulating centre spotted with white cylindrical conidia, circular, oval or lobed by confluence, forming large patches $5-6 \mathrm{~mm}$ long when confluent; young colonies consisting only of black lenticular conidia closely packed in a dome-like centre that remain together when 
pale brown to brown, smooth or finely verruculose to locally verruculose, verrucose or spinulose, thin or locally thick walled, branching and anastomosing forming a moderately dense network. Conidiophores micronematous, mononematous, cylindrical or slightly subulate, hyaline to pale brown, smooth or finely verruculose to verrucose, up to $20 \times 2-4.5 \mu \mathrm{m}$, often corresponding to the conidiogenous cells. Conidiogenous cells monoblastic, integrated, terminal, determinate, subhyaline to pale brown or brown, cylindrical, often arising directly on the superficial mycelium and closely packed together in the fertile centre, sphaerical, subsphaerical or ampulliform, smooth or finely verruculose, $4-7 \times 3-5 \mu \mathrm{m}$. Conidia of two types, solitary, dry; lenticular conidia muriform, smooth, broadly ellipsoidal, ellipsoidal or disc-shaped in front view, rarely subsphaerical, central cells brown to blackish brown or black, peripheral cells pale brown to brown or hyaline, forming a wide and distinct ring 3-5 $\mu \mathrm{m}$ wide, constricted at the septa, broadly ellipsoidal in side view where two distinct adpressed halves can be recognized, each half seen laterally as a row of 8-10 cells, end cells pale brown, middle cells blackish brown or black, often slightly attenuated at both round ends, (45-)49-56(-59) $\times(31-)$ 37-46 $\mu \mathrm{m}, 27-30 \mu \mathrm{m}$ thick, L/W = 1.30; cylindrical conidia straight or flexuous, septate, smooth, subhyaline, (37-) $49.5-60.5(67-) \times 18-28(-32) \mu \mathrm{m}$, consisting of two columns of (5-)6-7(-10) swollen cells each, usually appressed together but sometimes separated or rarely diverging, each column with 5-7 transverse septa, 10-19 $\mu \mathrm{m}$ at the widest part, constricted at the septa, often with 0-3 longitudinal or 0-2 oblique septa delimiting smaller cells toward the apex, apical and subapical cells straight, curved or bent to one side, laterally or apically pigmented brown to blackish brown, often a lateral cells is formed and delimited by a longitudinal or oblique septum at the subapical level, protruding and pigmented or not, sometimes short, curved, single columns up to four cells are formed laterally at the middle or basal cells, apical cell rounded or flattened, (9-)14-24(-28) $\mu \mathrm{m}$ wide, basal cells $12-19 \mu \mathrm{m}$ wide. Sexual morph unknown.

Cultures (Fig. 3G-I): Colonies moderately slow growing reaching on MEA 10-14 mm diam, on PCA 10-12 mm, and on PDA 17-18 mm after $7 \mathrm{~d}$ at $25{ }^{\circ} \mathrm{C}$. No sporulation observed after $4 \mathrm{~m}$ at $25^{\circ} \mathrm{C}$.

Notes: Hermatomyces megasporus is a morphologically remarkable species with large lenticular conidia and the largest cylindrical conidia among all currently recognized species of the genus. It is comparable to $H$. dimorphus (Rao \& de Hoog 1986) in conidial morphology and septation, with cylindrical conidia having transverse, longitudinal and oblique septa in both species. The two species differ, however, in the size and number of columns and cells, with $H$. dimorphus having smaller cylindrical conidia, 15-40 × 10-15 $\mu \mathrm{m}$, and four columns, each of seven cells. It also lacks the short, lateral columns of cells sometimes formed around the middle or basal portions of the conidia. Pigmentation usually occurs along a central column or between two opposite columns in side view, and extends beyond the middle of the conidia instead of apically or subapically as in $H$. megasporus. The lenticular conidia, however, are similar in size, reaching 35-55 $\mu \mathrm{m}$ diam in $H$. dimorphus but narrower in side view being only
15-20 $\mu \mathrm{m}$ thick. Compared to other known Hermatomyces species, both $H$. megasporus and $H$. dimorphus show a similar trend in a substantial increase in the number of cells connected with their decrease in size.

Additional material examined: Panama: Chiriquí Province: Boquete, Bajo Mono, pipe line trail, $8^{\circ} 49^{\prime} 40.22^{\prime \prime} \mathrm{N} 82^{\circ} 29^{\prime} 26.11^{\prime \prime} \mathrm{W}, 1720 \mathrm{~m}$ a.s.I., on rotten twig of unknown shrub, 19 Jul. 2016, O. Koukol KZP300 (PRM 946198, CCF 5897-living culture).

Hermatomyces reticulatus (M.L. Farr \& Goos.) Koukol \& G. Delgado, comb. nov. MycoBank MB824247

(Figs 7, 14A, D, G, J, 17A)

Basionym: Subicularium reticulatum M.L. Farr \& Goos, Mem. N. Y. bot. Gdn. 49: 66 (1989)

Synonym: Hermatomyces subiculosus C.G. Lin et al., Fungal Diversity 80: 73 (2016); as 'subiculosa'.

Type: Venezuela: Miranda State: Parque Nacional Guatopo, road between Santa Teresa and Los Alpes, on wood, 29 Jun1971, K.P. Dumont, J.H. Haines \& C. Blanco (BPI 1100692 - holotype).

Description: Colonies on the natural substrate in the form of sporodochial, subiculate conidiomata, superficial, scattered or crowded and confluent, more or less circular, oval or lobed, brown-black, consisting of a well-developed, velvety, dense, thick, annular, grayish brown sterile mycelial outer zone enclosing a black, glistening, abundantly sporulating granulose centre, circular, oval or lobed by confluence, where conidia are compactly appressed, though easily liberated when touched, 250-750 $\mu \mathrm{m}$ diam when single, forming large patches on the substrate 4-6 mm long when confluent. Mycelium superficial, composed of a compact network of repent, branched, septate, smooth or verruculose, locally thick walled, brown to dark brown hyphae, 2-4.5 $\mu \mathrm{m}$ wide, subicular hyphae septate, branched, flexuous, undulate or irregularly geniculate, pale brown to brown, finely verruculose to locally smooth or verrucose, profusely branching, curving and anastomosing forming a dense network. Conidiophores micronematous or semimacronematous, mononematous, cylindrical, smooth or finely verruculose, pale brown, up to 13 $\mu \mathrm{m}$ long, $4-5 \mu \mathrm{m}$ wide, often corresponding to conidiogenous cells. Conidiogenous cells monoblastic, integrated, terminal, cylindrical, determinate, subhyaline to pale brown, often arising directly on the superficial mycelium and closely packed together at the fertile centre, sphaerical, subsphaerical or ampulliform, 5-9 × 3-5 $\mu \mathrm{m}$. Conidia of one type, globose, subglobose, broadly ellipsoidal, oblong or somewhat irregular in front view, ellipsoidal or narrowly oblong to oblong in side view where two distinct adpressed halves can be recognized, each half seen laterally as a row of 5-9 cells, sometimes with a deep constriction between halves, end cells and cells along the constriction often pale brown, muriform, with transverse, longitudinal and oblique septa, 4-celled (rarely 3-celled), subhyaline to pale brown and verruculose when young, dark brown to blackish brown and verrucose at maturity, (29.5-) $3-40(-45) \times 25-34(-41) \mu \mathrm{m}, 22-30 \mu \mathrm{m}$ thick, L/W = 1.20. Sexual morph unknown. 

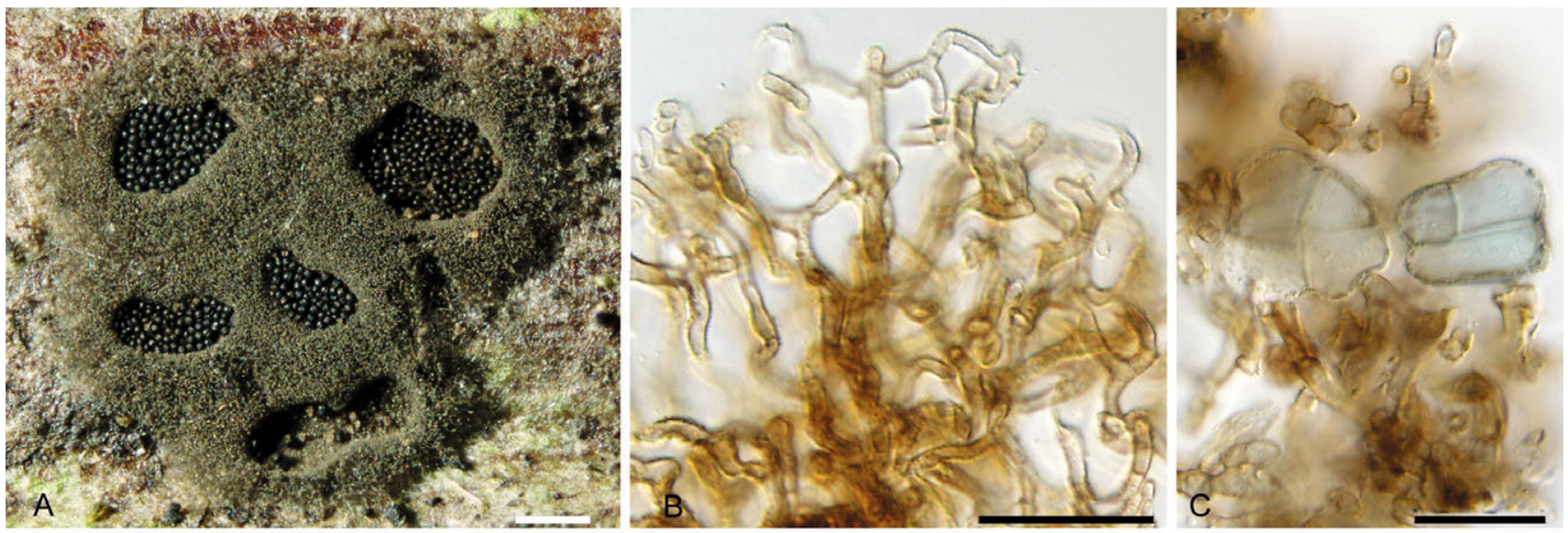

$D$
$\frac{1}{1}$
드

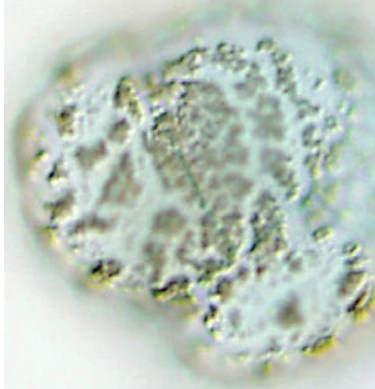

D

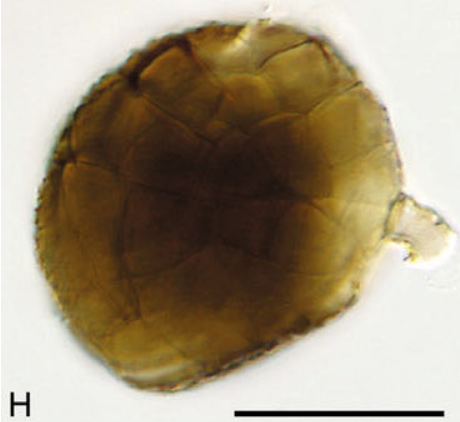

$\mathrm{H}$

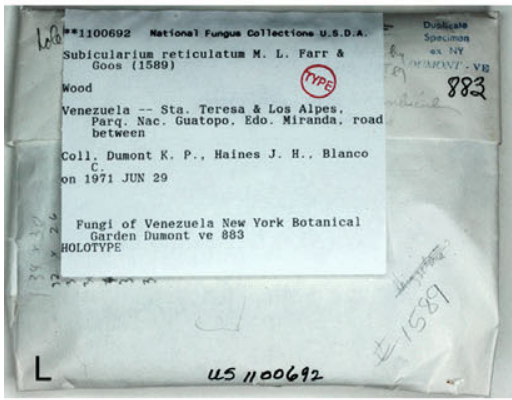

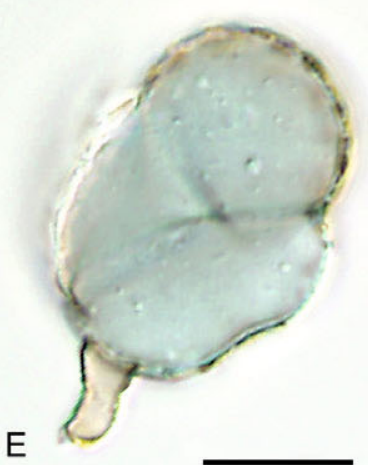

E
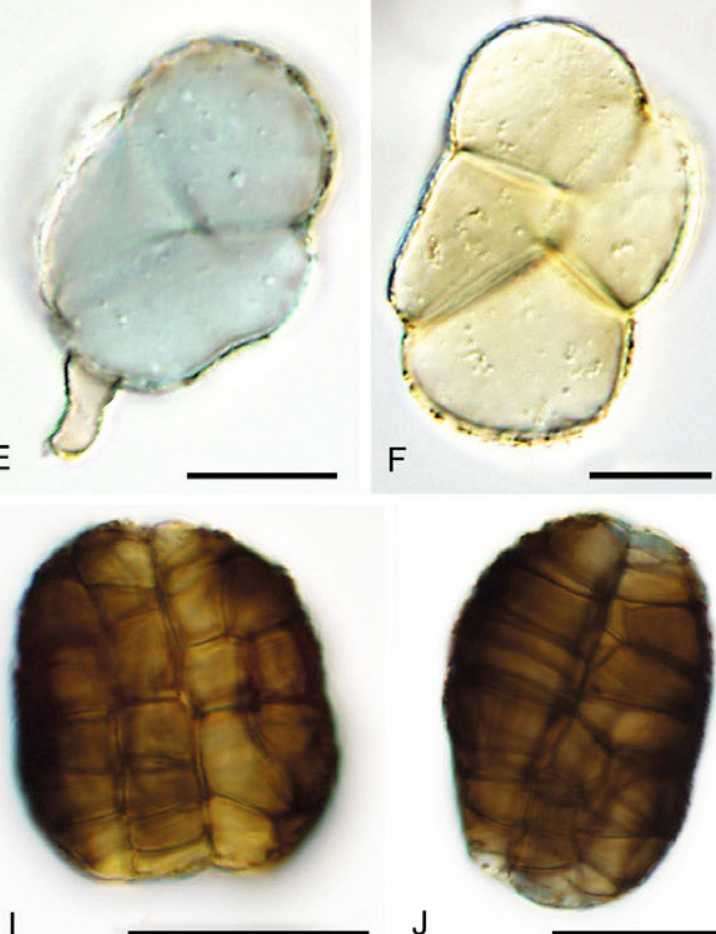

$\mathrm{F}$

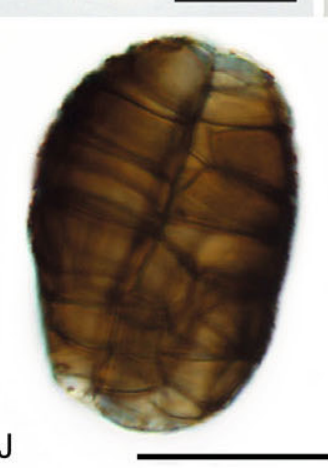

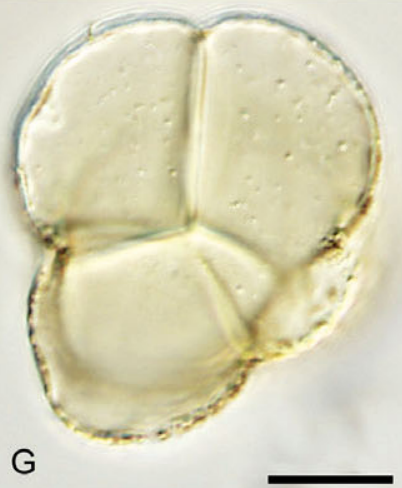

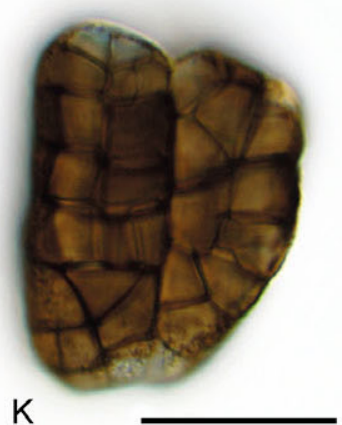

$\mathrm{K}$

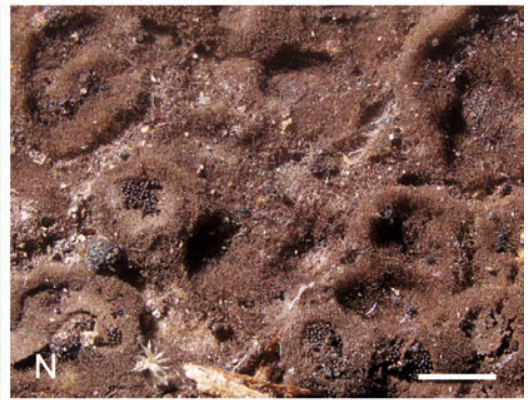

M
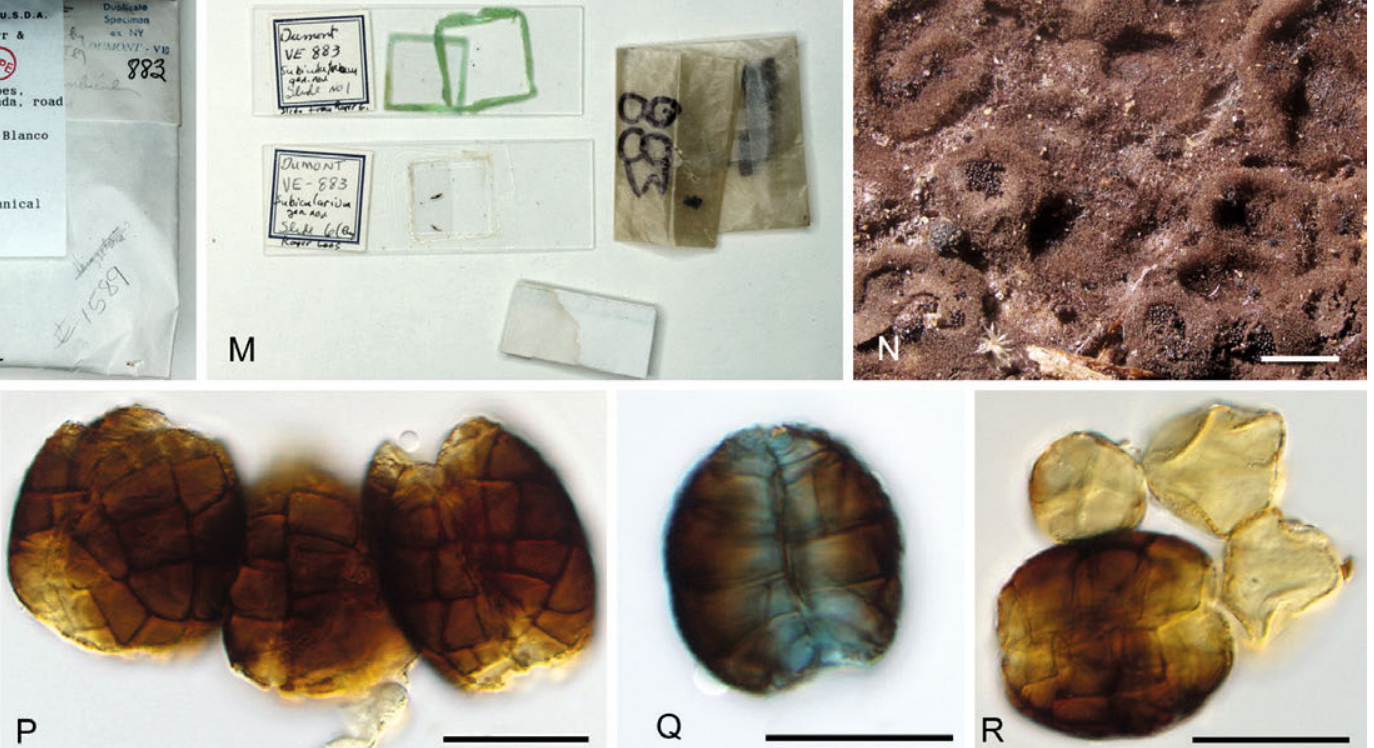

o

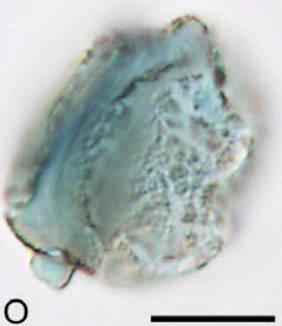

P

Fig. 7. Hermatomyces reticulatus (PMA 116078 - holotype). A. Colonies on the natural substrate showing well-developed subiculum. B. Subicular hyphae. C-G. Young lenticular conidia (stained with lacto-cotton blue at C-E). H-K. Mature lenticular conidia. L-M. Envelope and content of the holotype of Subicularium reticulatum (BPI 1100692). N. Colonies on the natural substrate. O. Young conidium (stained with lacto-cotton blue). P-R. Mature conidia (stained with lacto-cotton blue at Q). Bar $A=500 \mu \mathrm{m}, \mathrm{B}-\mathrm{G}=10 \mu \mathrm{m}, \mathrm{H}-\mathrm{K}=20 \mu \mathrm{m}, \mathrm{N}=500 \mu \mathrm{m}, \mathrm{O}=10 \mu \mathrm{m}, \mathrm{P}-\mathrm{R}=20 \mu \mathrm{m}$. 
Cultures (Fig. 3J-L): Colonies moderately slow growing reaching on MEA 14-15 mm diam, on PCA 10-12 mm, and on PDA $12-13 \mathrm{~mm}$ after $7 \mathrm{~d}$ at $25^{\circ} \mathrm{C}$. No sporulation observed after $4 \mathrm{~m}$ at $25^{\circ} \mathrm{C}$.

Notes: The presence of lobed lenticular conidia that are 4-celled when young, verrucose, dark brown and variably shaped at maturity with numerous oblique septa and lacking the paler ring of peripheral cells, makes $H$. reticulatus distinct from other species of Hermatomyces with one conidium type. Another distinct feature is the formation of a very compact layer of conidia in the sporulating centre of the colony caused by the irregular shape of the conidia (Fig. 14G). This species was first described by Farr \& Goos (1989) from a piece of wood in Venezuela as S. reticulatum. A re-examination of the holotype (BPI 1100692) revealed a fungus morphologically identical to our collections from Panama in the shape and septation of the conidia, particularly the presence of longitudinal and oblique septa (Fig. 6O-R). Conidia are also similar in size having 28-35 $\mu \mathrm{m}$ long and 26-32 $\mu \mathrm{m}$ wide.

Molecular sequence data retrieved from the Panama collections clustered in all phylogenies with ex-type sequences of $H$. subiculosus described by Hyde et al. (2016) from decaying wood in Thailand, but their phenotypic characteristics were slightly different. Conidia in the holotype are smaller, 15-35 $\mu \mathrm{m}$ long and 18-30 $\mu \mathrm{m}$ wide at the broadest part (Hyde et al. 2016), but considering their identical sequences, this phenotypic difference can be attributed to intraspecific variability. Hyde et al. (2016) suggested the monotypic Subicularium to be a later synonym of Hermatomyces and also considered S. reticulatum a later synonym of Scyphostroma mirum. Based on our morphological study of the holotype of Subicularium reticulatum and the results of molecular analyses, we make the new combination $H$. reticulatus and reduce $H$. subiculosus to synonymy.

Additional material examined: Panama: Chiriquí Province: west of Los Algarrobos, path through pastures along Majagua river, $8^{\circ} 29^{\prime} 47.82^{\prime \prime} \mathrm{N} 82^{\circ} 26^{\prime} 19.721^{\prime \prime} \mathrm{W}, 110 \mathrm{~m}$ a.s.l., on rotten twig of unknown tree, 8 Jul. 2016, O. Koukol KZP191 (PRM 946199; CCF 5893 - living culture); ibid., on dry rotten twig of unknown tree, 14 Jul, 2017, O. Koukol KZP409 (PMA 116078; CCF 5905 - living culture); ibid. on wet rotten liana, 14 Jul, 2017, O. Koukol KZP414 (PRC 4098; CCF 5910 - living culture).

Hermatomyces sphaericoides Koukol \& G. Delgado, sp. nov.

MycoBank MB824248

(Figs 8, 14B, E, H, K, 17B)

Etymology: sphaericoides, recalling $H$. sphaericus, to which it is morphologically similar.

Diagnosis: Differs from the morphologically close $H$. sphaericus in the consistently dark brown to blackish brown, finely verruculose lenticular conidia, ellipsoidal in side view and with an inconspicuous or narrow outer ring of peripheral cells.
Type: Panama: Chiriquí Province: west of Los Algarrobos, path through pastures along Majagua river, $8^{\circ} 29^{\prime} 47.82^{\prime \prime} \mathrm{N}$ $82^{\circ} 26^{\prime} 19.721^{\prime \prime} \mathrm{W}, 110 \mathrm{~m}$ a.s.l., on dry rotten twig of unknown tree, 14 Jul. 2017, O. Koukol KZP412 (PMA 116079 holotype; CCF 5908 - ex-holotype living culture).

Description: Colonies on the natural substrate forming sporodochial, subiculate conidiomata, superficial, more or less circular, oval or lobed, scattered or crowded and confluent, dark gray-black, consisting of a velvety, dense, thick, annular, dark gray, sterile mycelial outer zone enclosing a black, glistening, flattened, abundantly sporulating granulose centre, circular, oval or lobed by confluence, where conidia are easily liberated when touched, 400-700 $\mu \mathrm{m}$ diam when solitary, up to $1500 \mu \mathrm{m}$ long when confluent. Mycelium superficial, composed of a compact network of repent, branched, septate, smooth, pale brown or brown hyphae, 1.5-3.5 $\mu \mathrm{m}$ wide, subicular hyphae septate, pale brown, brown in mass, branched, mostly smooth but locally verrucose or sometimes finely verruculose, flexuous, undulate or strongly geniculate, branching and anastomosing to form a dense network. Conidiophores inconspicuous, rarely seen, up to $14 \mu \mathrm{m}$ long and $3.5 \mu \mathrm{m}$ wide, often corresponding to conidiogenous cells. Conidiogenous cells monoblastic, determinate, arising directly on the superficial mycelium and closely packed together at the fertile centre, sphaerical, subsphaerical, ellipsoidal or ampulliform, pale brown, smooth or finely verruculose, 3-7 $\times 2-5 \mu \mathrm{m}$. Conidia of one type, solitary, dry, lenticular, globose, subglobose, broadly ellipsoidal or rarely disc-shaped in front view, muriform, sometimes slightly constricted at the septa, finely verruculose, central cells dark brown to blackish brown, peripheral cells narrow and brown, rarely pale brown, ellipsoidal or oblong in side view where two distinct adpressed halves can be recognized, each half seen laterally as a row of 5-7 cells, end cells pale brown to brown, middle cells dark brown to blackish brown, with a narrow, sometimes deep constriction between them, (20.5-) 24.5-28(-31) x (20-)23-26(-29) $\mu \mathrm{m},(15-) 19-25 \mu \mathrm{m}$ thick, $\mathrm{L} / \mathrm{W}=1.08, \mathrm{~L} / \mathrm{T}=1.26$. Sexual morph unknown.

Cultures (Fig. 3M-O): Colonies moderately slow growing reaching on MEA 12-13 $\mathrm{mm}$ diam, on PCA 14-16 mm, and on PDA $14-16 \mathrm{~mm}$ after $7 \mathrm{~d}$ at $25^{\circ} \mathrm{C}$. Sporulation on PDA late, within $4 \mathrm{~m}$ at $25^{\circ} \mathrm{C}$ and observed only in one (KZP470) out of five strains. Lenticular conidia (22.5-)24.5-28(-30) $\times$ 22.5-26.5(-29) $\mu \mathrm{m}$ and 19-23 $\mu \mathrm{m}$ thick.

Notes: Hermatomyces sphaericoides is hardly distinguishable from $H$. sphaericus on morphological grounds, as indicated by the specific epithet. The two species are, however, phylogenetically distinct and collections of both taxa grouped distantly in all phylogenies (Figs 1-2). Morphologically, in contrast to $H$. sphaericus, the conidia of $H$. sphaericoides are consistently dark brown to blackish brown and finely verruculose with the outer ring of peripheral cells inconspicuous or narrow and brown, sometimes only slightly constricted at the septa. Further differences can be found in side view where conidia of $H$. sphaericoides tend to be more ellipsoidal $(\mathrm{L} / \mathrm{T}=1.26)$ compared to broadly ellipsoidal in $H$. sphaericus $(L / T=1.22)$ although this difference was not 


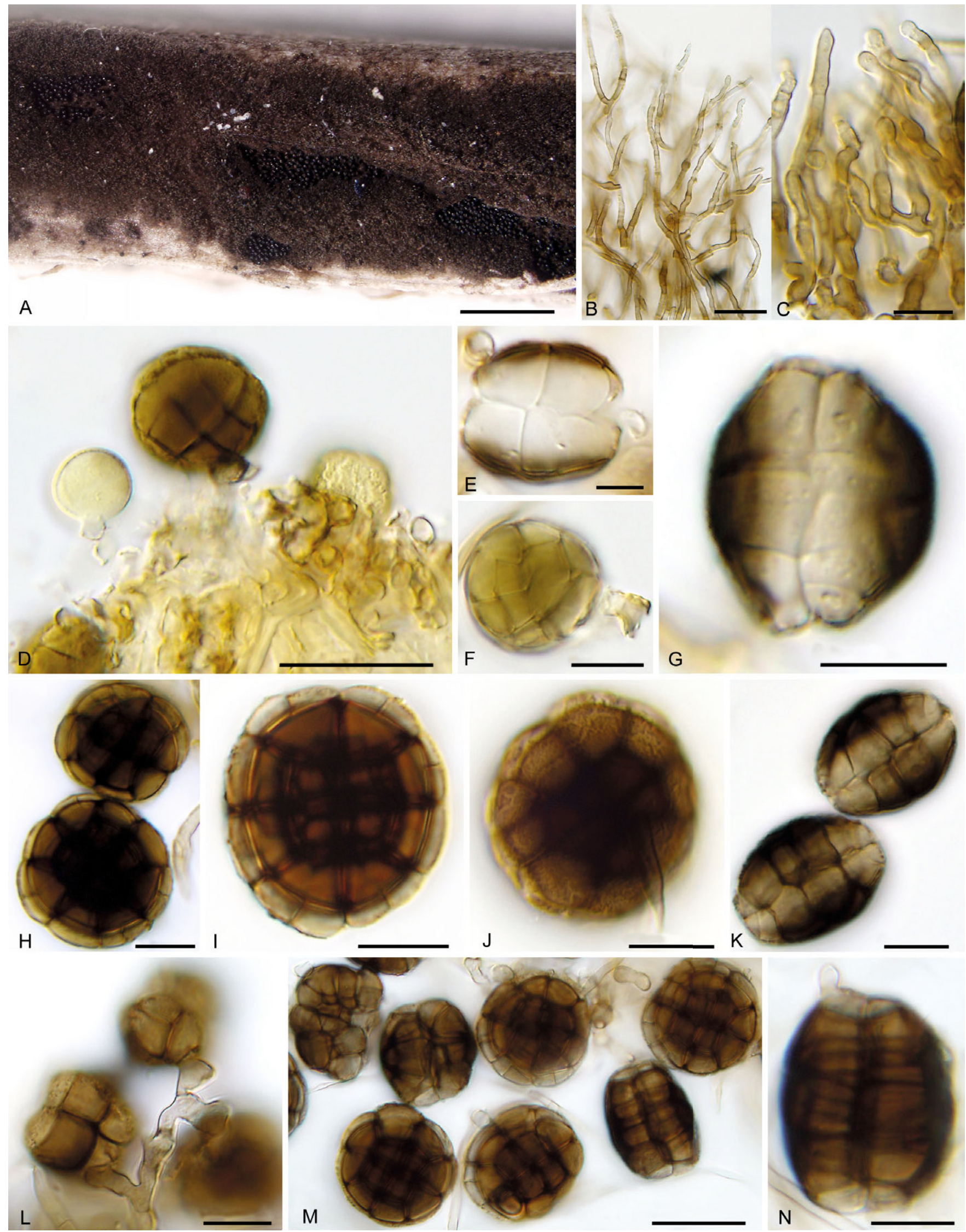

$D$
D্]
$\frac{1}{n}$
ח

Fig. 8. Hermatomyces sphaericoides (PMA 116079 - holotype) A. Colonies on the natural substrate. B-C. Subicular hyphae. D. Conidiogenous cells and young conidia. E-G. Young conidia. H-K. Mature conidia. L-N. Conidia on PDA. Bar A = 500 $\mu \mathrm{m}, \mathrm{B}=20 \mu \mathrm{m}, \mathrm{C}-\mathrm{L}=10 \mu \mathrm{m}, \mathrm{M}=20$ $\mu \mathrm{m}, \mathrm{N}=10 \mu \mathrm{m}$. 
significant. Subicular hyphae are mostly smooth or sparingly verrucose, less compact and forming a dark gray subiculum around the fertile centre but combinations of some of these features were similarly found in $H$. sphaericus specimens.

Additional material examined: Panama: Chiriquí Province: west of Los Algarrobos, path through pastures along Majagua river, $8^{\circ} 29^{\prime} 47.82^{\prime \prime} \mathrm{N} 82^{\circ} 26^{\prime} 19.721^{\prime \prime} \mathrm{W}, 110 \mathrm{~m}$ a.s.l., on dry rotten twig of unknown tree, 14 Jul. 2017, O. Koukol KZP411 (PRM 946200; CCF 5907 - living culture); Los Algarrobos, path to Majagua river, $8^{\circ} 29^{\prime} 13.86^{\prime \prime} \mathrm{N} 82^{\circ} 26^{\prime} 2.881^{\prime \prime} \mathrm{W}, 105 \mathrm{~m}$ a.s.I., on rotten leaf of Astrocaryum standleyanum (Arecaceae), 8 Jul. 2017, O. Koukol KZP320 (PRC 4102; CCF 5895- living culture); ibid., on rotten petiole of unknown liana leaf, 8 Jul. 2017, O. Koukol KZP326 (PRC 4103; CCF 5896- living culture); Bocas del Toro Province: along the road between Almirante and Rambála, 9¹0'1.79"N 82¹8'57.27"W, $201 \mathrm{~m}$ a.s.I., on dry rotten stem of unknown liana, 22 Jul. 2017, O. Koukol KZP470 (UCH).

Hermatomyces sphaericus (Sacc.) S. Hughes, Mycol. Pap. 50: 100 (1953).

(Figs 9, 10, 14C, F, I, L, 17C)

Basionym: Stemphylium sphaericum Sacc., Atti Accad. Sci. Ven.-Trent.-Istr. 10: 86 (1917).

Synonyms: Hermatomyces chromolaenae Jin $\mathrm{F}$. Li et al., Index Fungorum 342: 1 (2017).

Hermatomyces saikhuensis Tibpromma et al., Phytotaxa 275: 134 (2016).

Hermatomyces tectonae Doilom et al., Fungal Div. 82: 117 (2016).

Type: Philipines: Laguna: Los Baňos, on decorticated braches of Barleria cristata (Acanthaceae). Dec. 1915, C. F. Baker [Fungi Malayana no. 395] (K(M) IMI 37763 - holotype).

Description: Colonies on the natural substrate in the form of sporodochial, subiculate conidiomata, superficial, more or less circular, oval or lobed, scattered or crowded and confluent, brown-black or gray-black, consisting of a velvety, dense, thick, annular, brown or gray, sterile mycelial outer zone enclosing a black, glistening, abundantly sporulating granulose centre, circular, oval or lobed by confluence where conidia are easily liberated when touched, 300-800 $\mu \mathrm{m}$ diam when solitary, up to $1600 \mu \mathrm{m}$ long when confluent. Mycelium superficial, composed of a tightly compact network of repent, branched, septate, smooth or finely verruculose, locally thick-walled, brown hyphae, 2-4 $\mu \mathrm{m}$ wide, subicular hyphae flexuous, undulate, strongly or irregularly geniculate, subhyaline or pale brown to brown, branched, smooth, finely verruculose or locally verrucose, branching and anastomosing to form a dense network. Conidiophores micronematous, mononematous, cylindrical or forked once, subhyaline or pale brown, up to 15 long and 2-4 $\mu \mathrm{m}$ wide, often corresponding to conidiogenous cells. Conidiogenous cells monoblastic, integrated, terminal, cylindrical, determinate, subhyaline to pale brown, smooth or finely verruculose, often arising directly on the superficial mycelium and closely packed together at the fertile centre, sphaerical, subsphaerical or ampulliform, 4-10 $\times 3-4 \mu \mathrm{m}$. Conidia of one type, solitary, dry, lenticular, globose, subglobose, disc-shaped or broadly ellipsoidal in front view, muriform, smooth or verruculose, central cells brown, dark brown to blackish brown, sometimes all cells brown and muriform septation visible, outer ring of peripheral cells narrow or wide, pale brown to brown, often constricted at septa, broadly ellipsoidal or oblong in side view where two distinct adpressed halves can be recognized, each half seen laterally as a row of 4-7 cells, end cells subhyaline to pale brown, middle cells brown to blackish brown, with a narrow, sometimes deep constriction between them, (21-)24-29($32.5) \times(18-) 21-27(-31.5) \mu \mathrm{m}, 16-23.5(-28) \mu \mathrm{m}$ thick, L/W $=1.08, \mathrm{~L} / \mathrm{T}=1.22$.

Cultures (Fig. 3P-R): Colonies moderately slow growing reaching on MEA 13-17 mm diam, on PCA12-16 mm, and on PDA $12-16 \mathrm{~mm}$ after $7 \mathrm{~d}$ at $25^{\circ} \mathrm{C}$. Sporulation on PDA late within $4 \mathrm{~m}$ at $25^{\circ} \mathrm{C}$ and observed only in one (CCF 5911) of 12 strains. Lenticular conidia (24.5-)26.5-30(-31.5) $\times 22.5-$ $29 \mu \mathrm{m}$ and (18.5-)21-25.5 $\mu \mathrm{m}$ thick.

Notes: Hermatomyces sphaericus was the first species with one conidium type transferred into the genus (Hughes 1953). Our numerous collections match well with the type collection (K(M)-IMI 37763) and Hughes' description based on his specimens from bark of Albizia gummifera (Mimosaceae), Averrhoa carambola (Oxalidaceae), Theobroma cacao (Sterculidaceae), and rachides of leaves of Elais guineensis (Arecaceae) collected in Ghana. He described the lenticular conidia as $26-31 \times 25-30 \mu \mathrm{m}$ and $20-25 \mu \mathrm{m}$ thick. Other specimens described in the literature are reported as having similar or slightly smaller conidia. Holubová-Jechová \& Mercado (1986) reported conidia as 24-28.8 × 24-27 $\mu \mathrm{m}$ and 16.6-21 $\mu \mathrm{m}$ thick for a specimen collected on a dead branch from Cuba (PRM 838101) and revised in this study, while Heredia et al. (1997) described conidia as 24-29 × 24$30 \mu \mathrm{m}$ and $15-21 \mu \mathrm{m}$ thick for specimens collected on fallen twigs and branches of angiosperms and on a palm petiole in Mexico. Zhang et al. (2009) provided conidial dimensions of 23-29 $\times 22-26 \mu \mathrm{m}$ for specimens collected on a dead branch of Rauvolfia vomitoria (Apocynaceae) and dead wood of Tectona grandis (Lamiaceae) in China. Mel'nik (2000) reported conidia $26-31 \times 25-30 \mu \mathrm{m}$ and $25-30 \mu \mathrm{m}$ thick for a specimen collected on dry thin branches of Larix sibirica (Pinaceae) in Russia, which is, however, questionable, because it represents the only record outside the tropics.

Examination and comparison of the specimens from Panama revealed morphological variability in other features, e.g. the subiculum in PRC 4100 was brown and composed of strongly geniculate, brown, smooth or finely verruculose hyphae forming compact masses, while the subiculum in PRC 4105 was gray and composed of subhyaline to pale brown, irregularly geniculate, undulate and loose hyphae with some degree of ornamentation, finely verruculose to locally verruculose. Conidial ornamentation was mainly verruculose throughout Panamanian specimens. Re-examination of PRM 838101 from Cuba also revealed the presence of verruculose conidia. Surprisingly, this feature has been rarely mentioned in descriptions of $H$. sphaericus and wall ornamentation, if smooth or not, has often been overlooked for both conidia and subicular hyphae. The only exceptions were Hughes (1953), who described subicular hyphae as smooth, and Zhang 

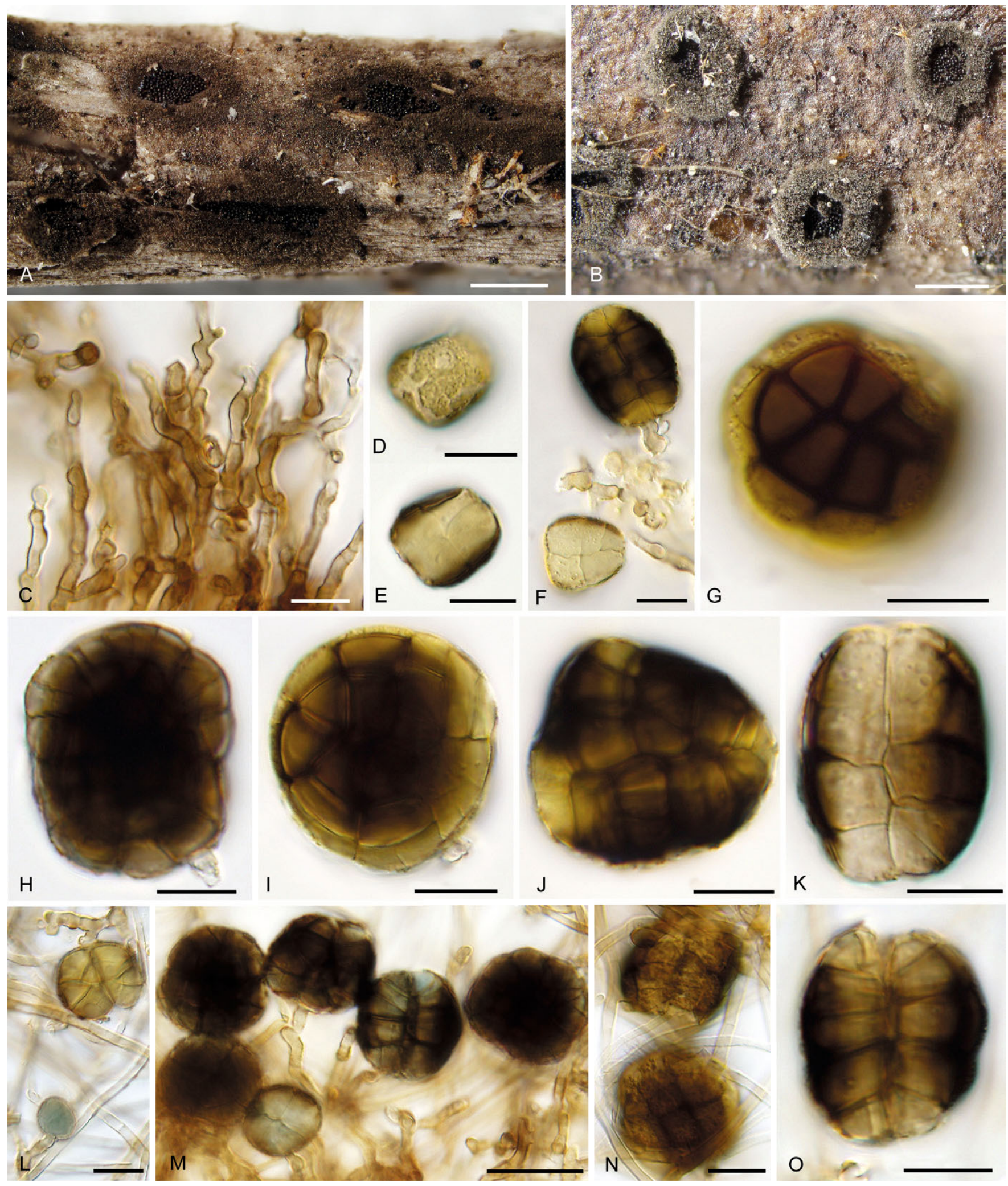

Fig. 9. Hermatomyces sphaericus (PMA 116080) A-B. Colonies on the natural substrate showing morphological variability. C. Subicular hyphae. D-G. Young conidia. H-K. Mature conidia. L. Young conidia on PDA (stained with lacto-cotton blue at L-M). M-O. Mature conidia on PDA. Bar $A-B=500 \mu \mathrm{m}, C-L=10 \mu \mathrm{m}, \mathrm{M}=20 \mu \mathrm{m}, \mathrm{N}-\mathrm{O}=10 \mu \mathrm{m}$.

et al. (2009) who mentioned smooth conidia. Indeed, the conidia in permanent slides of the holotype (Fig. 10B-D) are either smooth or inconspicuously verruculose. Sporulation in culture media, on the other hand, was rare with only one of 12 isolates able to produce conidia after $4 \mathrm{~m}$ of incubation.
In contrast, Zhang et al. (2009) reported sporulation of two strains after $6-10 \mathrm{~d}$ when grown on PDA at $24-25^{\circ} \mathrm{C}$ in the only reference to cultural data available so far for $H$. sphaericus. These examples, based on several collections of different origins, show that $H$. sphaericus is a plurivorous, 


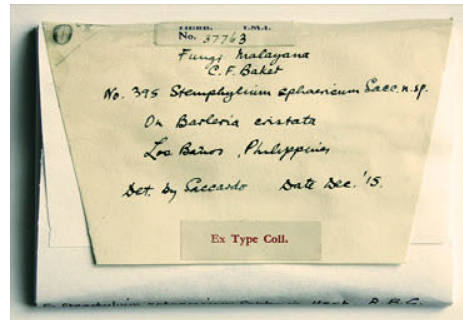
A O瞇
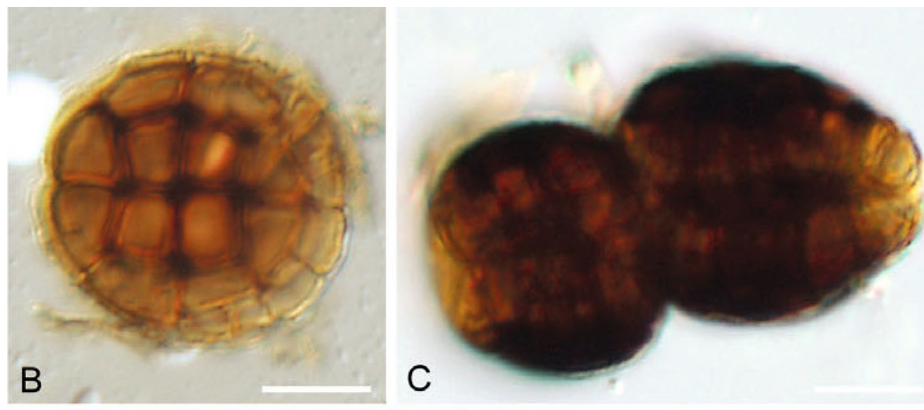

C
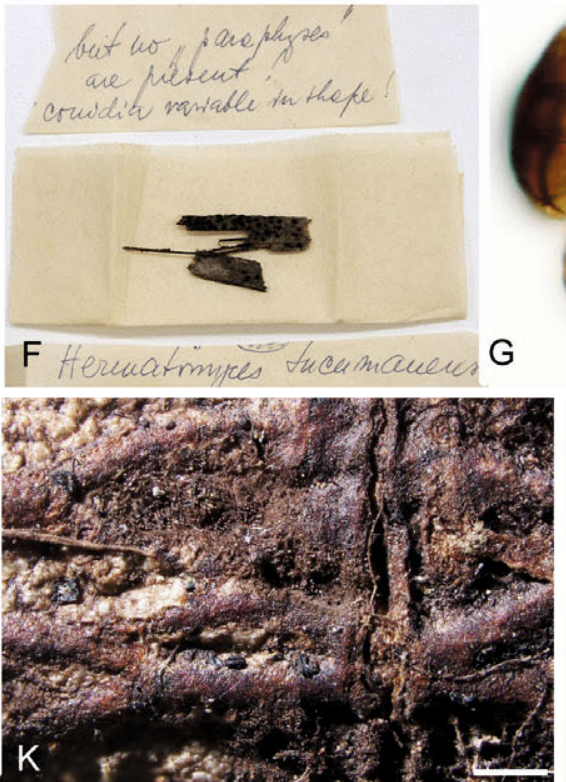
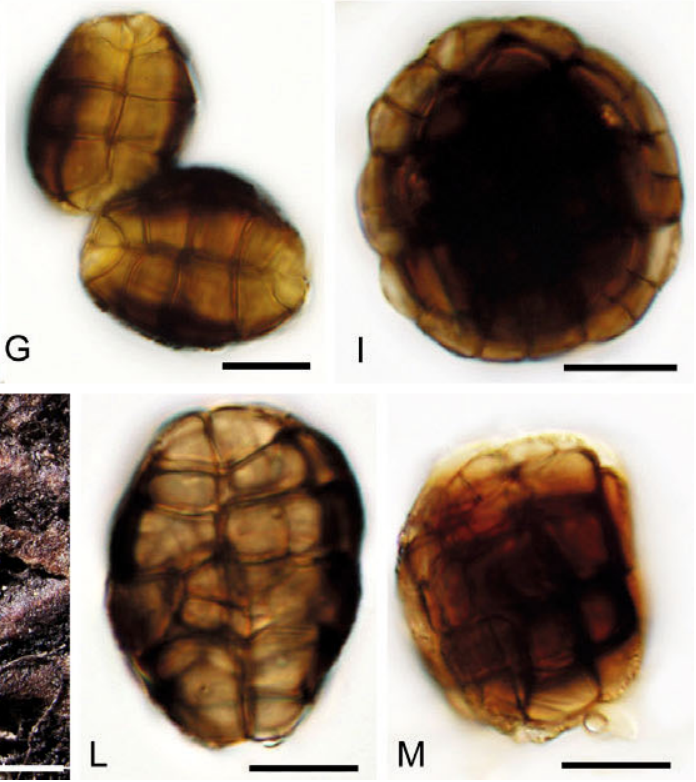
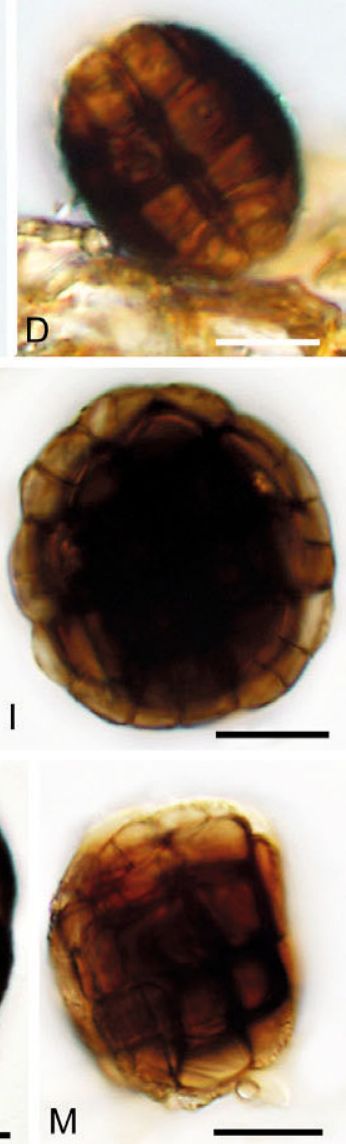

Fig. 10. Revised fungarium collections of Hermatomyces sphaericus A. Envelope of the holotype of Stemphylium sphaericum (K(M) IMI 37763). B-D. Mature conidia. E. Envelope of collection PRM 842348. F. Content of the envelope including remarks on morphology. G-I. Mature conidia. J. Envelope of collection PRM 838101 . K. Colony on the substrate. L-M. Mature conidia. Bar B-D = $10 \mu \mathrm{m}, \mathrm{G}-\mathrm{I}=10 \mu \mathrm{m}, \mathrm{K}=500 \mu \mathrm{m}, \mathrm{L}-\mathrm{M}=$ $10 \mu \mathrm{m}$.

morphologically variable species whose morphology may depend either on environmental or cultural conditions, the plant species on which the fungus is growing and possibly also to the age of the colony.

Hermatomyces sphaericus has been further recorded on the dead rachis and petiole of Archontophoenix alexandrae from Hong Kong and Singapore (Taylor \& Hyde 2003), on dead leaves of Chamaedorea sp. (both Arecaceae) and plant debris from Mexico (Heredia \& Mercado 1998, Becerra et al. 2007), on branches and leaf litter of Shorea sp. (Dipterocarpaceae) in Indonesia (Harahap 2013), on dead branches and wood of Syzygium jambos (Myrtaceae) and Pisonia aculeata (Nyctaginaceae), respectively, from Cuba (Delgado et al. 2002, Mercado et al. 2002) and on submerged twigs and twigs in bird nests from Brazil (Barbosa \& Gusmão 2011, Conceição \& Marques 2015). It is considered the most widespread species in the genus (Hashimoto et al. 2017) with a pantropical distribution. However, in the absence of available voucher specimens or molecular data, the distribution of $H$. sphaericus in all the countries mentioned in the literature cannot be confirmed. In view of the high morphological similarity with $H$. sphaericoides and in the absence of reference molecular data, we consider $H$. sphaericus to be the widespread species while $H$. sphaericoides is currently known only from Panama.
In this context, two recently described species with one conidium type, $H$. saikhuensis and $H$. chromolaenae, represent $H$. sphaericus based on morphological and molecular data and are considered conspecific here. They were described based on single isolates collected on dead leaves of Pandanus odorifer (Pandanaceae) and a dead stem of Chromolaena odorata (Asteraceae) (Tibpromma et al. 2016, 2017), respectively, in Thailand. The phenotypic differences, mainly smaller lenticular conidia, 14-21.5 × 11$19 \mu \mathrm{m}$ for $H$. saikhuensis and 9-10.5 $\times 10-11.5 \mu \mathrm{m}$ for $H$. chromolaenae, may be attributed to intraspecific variability. The sequences originating from ex-type cultures of these taxa clustered in all our phylogenies with the numerous sequences belonging to our specimens of $H$. sphaericus (Fig. 1). Although Tibpromma et al. (2017) observed some segregation in their phylogenies this should be considered artificial and a sequencing error. When available sequences from GenBank were clustered with our dataset, the only variability was found for LSU sequences on their flanking regions in an area where all other sequences are conserved.

Additional material examined: Panama: Chiriquí Province: Los Algarrobos, path to Majagua river, $8^{\circ} 29^{\prime} 13.86^{\prime \prime} \mathrm{N} 82^{\circ} 26^{\prime} 2.881^{\prime \prime} \mathrm{W}, 105$ m a.s.l., on heavily rotten leaf of Arecaceae, 12 Jul. 2016, P. Zehnálek KZP241 (PRC 4100; CCF - living culture); David, UNACHI, Botanical 
Garden, along San Cristobal river, 8²6’3.49”N 82²7'8.802”W, 45 m a.s.I., on dry rotten stem of unknown liana, 11 Jul 2017, L. Janošík KZP375 (PRC 4104; CCF 5902- living culture); ibid., on dry rotten stem of unknown liana, 11 Jul. 2017, L. Janošík KZP376 (PRC 4106; CCF 5902- living culture); ibid., on dry rotten hanging twig of Guazuma ulmifolia (Malvaceae), 19 Jul. 2017, O. Koukol KZP441 (UCH); west of Los Algarrobos, path through pastures along Majagua river, $8^{\circ} 29^{\prime} 47.82^{\prime \prime} \mathrm{N} 82^{\circ} 26^{\prime} 19.721^{\prime \prime} \mathrm{W}, 110 \mathrm{~m}$ a.s.I., on wet rotten stem of unknown liana, 14 Jul. 2017, O. Koukol KZP410 (PMA 116085; CCF 5906- living culture); ibid., on dry rotten twig of unknown tree, 14 Jul. 2017, O. Koukol KZP415 (PMA 116080; CCF 5911- living cultur); Boquete, Lago La Estrella, 843'44.09”N 82²3'2.465”W, 977 $\mathrm{m}$ a.s.l., on dry rotten hanging twig of unknown tree, 19 Jul. 2017, $O$. Koukol KZP445 (PMA 116081; CCF 5914- living cultur); Bocas del Toro Province: Changuinola, dirty road close to the old railway bridge, $9^{\circ} 24^{\prime} 21.85^{\prime \prime} \mathrm{N} 82^{\circ} 31^{\prime} 12.24$ 'W, $18 \mathrm{~m}$ a.s.l., dry rotten hanging twig of unknown Fabaceae, 20 Jul. 2017, O. Koukol KZP455 (PRC 4116); along the road between Almirante and Changuinola, 9 $21^{\prime} 57.54$ ' $\mathrm{N}$ $82^{\circ} 28^{\prime} 33.29^{\prime \prime} \mathrm{W}, 135 \mathrm{~m}$ a.s.l., on dry rotten hanging twig of unknown tree, 21 Jul. 2017, O. Koukol KZP457 (PRC 4108; CCF 5916- living culture); ibid., on dry rotten hanging unknown liana, 21 Jul. 2017, O. Koukol KZP458 (PRM 946201); along the road between Almirante and Changuinola, $9^{\circ} 20^{\prime} 46.66$ "N 82 $28^{\prime} 23.24$ 'W, $128 \mathrm{~m}$ a.s.I., on dry rotten hanging twig of unknown tree, $21 \mathrm{Jul}$. 2017, O. Koukol KZP459 (PMA 116082; CCF 5917- living culture); ibid., on dry rotten hanging twig of unknown tree, 21 Jul. 2017, O. Koukol KZP460 (PRC 4105); along the road between Almirante and Changuinola, $9^{\circ} 18^{\prime} 51.75^{\prime \prime} \mathrm{N}$ $82^{\circ} 27^{\prime} 0.47^{\prime \prime} \mathrm{W}, 52 \mathrm{~m}$ a.s.I., on dry rotten hanging twig of unknown tree, 21 Jul. 2017, O. Koukol KZP462 (UCH); along the road between Almirante and Rambála, 9`12'9.65”N 82 $20^{\circ} 48.80^{\prime \prime} \mathrm{W}, 36$ m a.s.I., dry rotten hanging twig of unknown tree, 22 Jul. 2017, O. Koukol KZP469 (PRC 4117). - Cuba: La Habana Province: Jaruco, Loma de la Coca, south of Campo Florido, on dead petiole of an undetermined palm tree (Arecaceae), 13 Feb. 1981, V. Holubová-Jechová (PRM 842348; as H. tucumanensis); Pinar del Rio, Sierra de Sumidero, Pica Pica valley, on dead branch, 10 Apr. 1981, V. Holubová-Jechová (PRM 838101).

Hermatomyces tucumanensis Speg., Anal. Mus. nac. B. Aires, ser. 3 13: 446 (1911).

(Figs 11, 15A, C, E, G, 16K)

Description: Colonies on the natural substrate in the form of sporodochial, subiculate conidiomata, superficial, more or less circular, oval or lobed, scattered or crowded and confluent, gray-black, consisting of a velvety, dense, thick, annular, gray, sterile mycelial outer zone enclosing a black or whitish black, glistening, abundantly sporulating granulose centre, circular, oval or lobed by confluence where cylindrical conidia are seen among the lenticular ones and are easily liberated when touched, 250-500 $\mu \mathrm{m}$ diam when solitary, up to $900 \mu \mathrm{m}$ long when confluent. Mycelium superficial, composed of a loose or compact network of repent, branched, septate, anastomosing, smooth or finely verruculose, locally verruculose or verrucose, thin or thick walled, pale brown to brown hyphae, 2-4 $\mu \mathrm{m}$ wide; subicular hyphae ascending, branched, septate, verruculose or verrucose, pale brown to brown, erect, flexuous, undulate or irregularly geniculate, branching and rarely anastomosing to form a moderately dense network. Conidiophores micronematous, mononematous, cylindrical, hyaline to pale brown, smooth, up to $12 \times 3-4 \mu \mathrm{m}$, often corresponding to conidiogenous cells. Conidiogenous cells monoblastic, integrated, terminal, determinate, often arising directly on the superficial mycelium and closely packed together at the fertile centre, subsphaerical, ovoid or ampulliform, pale brown to brown, smooth, 4-8 × 3-5 $\mu \mathrm{m}$. Conidia of two types, solitary, dry; lenticular conidia muriform, smooth, ellipsoidal in front view, central cells mostly black or dark brown to blackish brown, peripheral cells hyaline to subhyaline, forming a distinct but often incomplete ring up to $4 \mu \mathrm{m}$ wide, slightly constricted at the septa or not, narrowly oblong in side view with the two halves not readily recognizable, each half seen laterally as a row of 6-7 cells, end cells hyaline to subhyaline, middle cells dark brown to blackish brown, (22-)27-35 × 18-25 $\mu \mathrm{m}, 12-17 \mu \mathrm{m}$ thick, L/W = 1.38; cylindrical conidia straight or slightly flexuous, septate, smooth, subcylindrical or obclavate, consisting of two columns of 3-6 cells each arising from one or two basal cells, each column with 3-5 transverse septa and sometimes with 0-1 oblique septa delimiting smaller cells toward the apex, hyaline, with a distinct dark brown pigmentation running from the top downwards and narrowing to a point close to the basal cell(s), apex rounded and widened, (21-)23-26(-28.5) × 7-14 $\mu \mathrm{m}$. Sexual morph unknown.

Cultures (Fig. 3S-U): Colonies moderately slow growing reaching on MEA 12-13 $\mathrm{mm}$ diam, on PCA 14-16 mm, and on PDA $14-16 \mathrm{~mm}$ after $7 \mathrm{~d}$ at $25^{\circ} \mathrm{C}$. No sporulation observed after $4 \mathrm{~m}$ at $25^{\circ} \mathrm{C}$.

Notes: Spegazzini (1911) described H. tucumanensis, the generic type, from a rotten branch of Smilax campestris (Smilacaceae) and Celtis sp. (Cannabaceae) in Argentina. It is evident from his fig. 65 that he considered the cylindrical conidia to be conidiophores ("sporophores"), bearing two melanized beaks with hanging lenticular conidia. This misinterpretation might have been caused by the limited quality of the optical equipment available at the time but also both types of conidia may give that impression when seen appressed together. Our three specimens match well the protologue of $H$. tucumanensis in the overall shape of conidia, but our measurements are smaller compared to those of Spegazzini (1911). He recorded lenticular conidia 35-40 $\times$ $30 \mu \mathrm{m}$ and 15-20 $\mu \mathrm{m}$ thick and "sporophores" (cylindrical conidia) 20-40 $\mu \mathrm{m}$ long with a similar thickness of 10-15 $\mu \mathrm{m}$. Leão et al. (2013) examined what they considered to be the holotype of $H$. tucumanensis (LPS15823) and also described larger conidia, the lenticular conidia being 31-42 × 14-16 $\mu \mathrm{m}$ and the cylindrical ones with two columns of $2-3$ cells each and 31-46 × 17-28 $\mu \mathrm{m}$. In view of similar differences between specimens of other taxa such as $H$. reticulatus, we suggest to consider them as the result of intraspecific variability.

Numerous collectors after Spegazzini subsequently recorded " $H$. tucumanensis" but descriptions in the literature and our study of available specimens suggest that the name became rather an "umbrella" species and was largely attributed to numerous morphologically different two conidium type and one conidium type species recorded in various countries and on diverse hosts. Hughes (1953) mentioned collections 

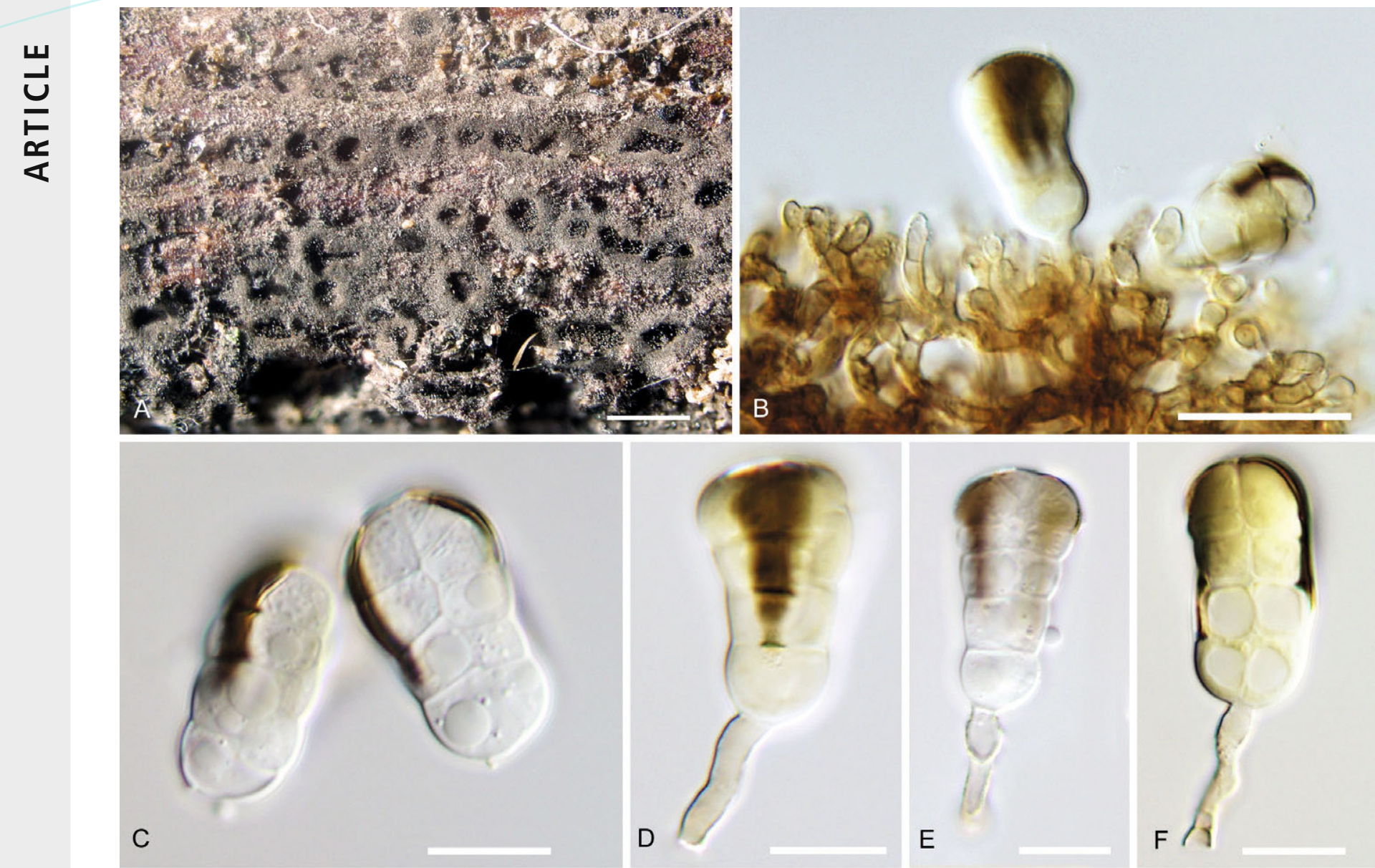

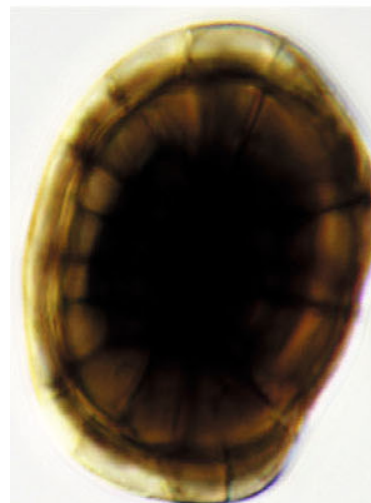

G

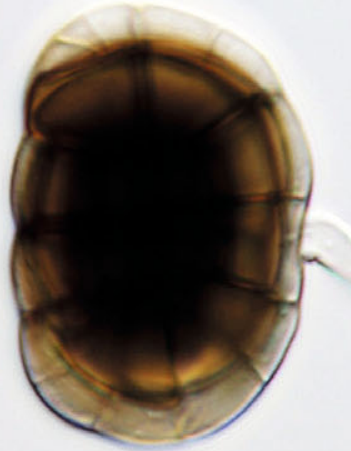

$\mathrm{H}$

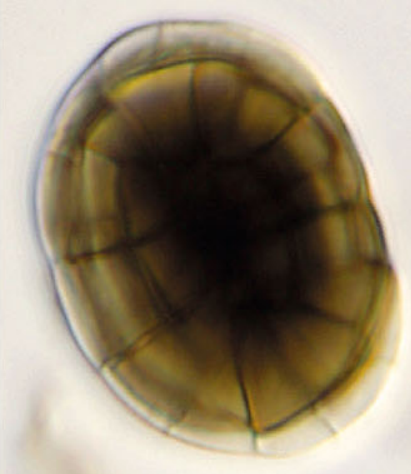

I
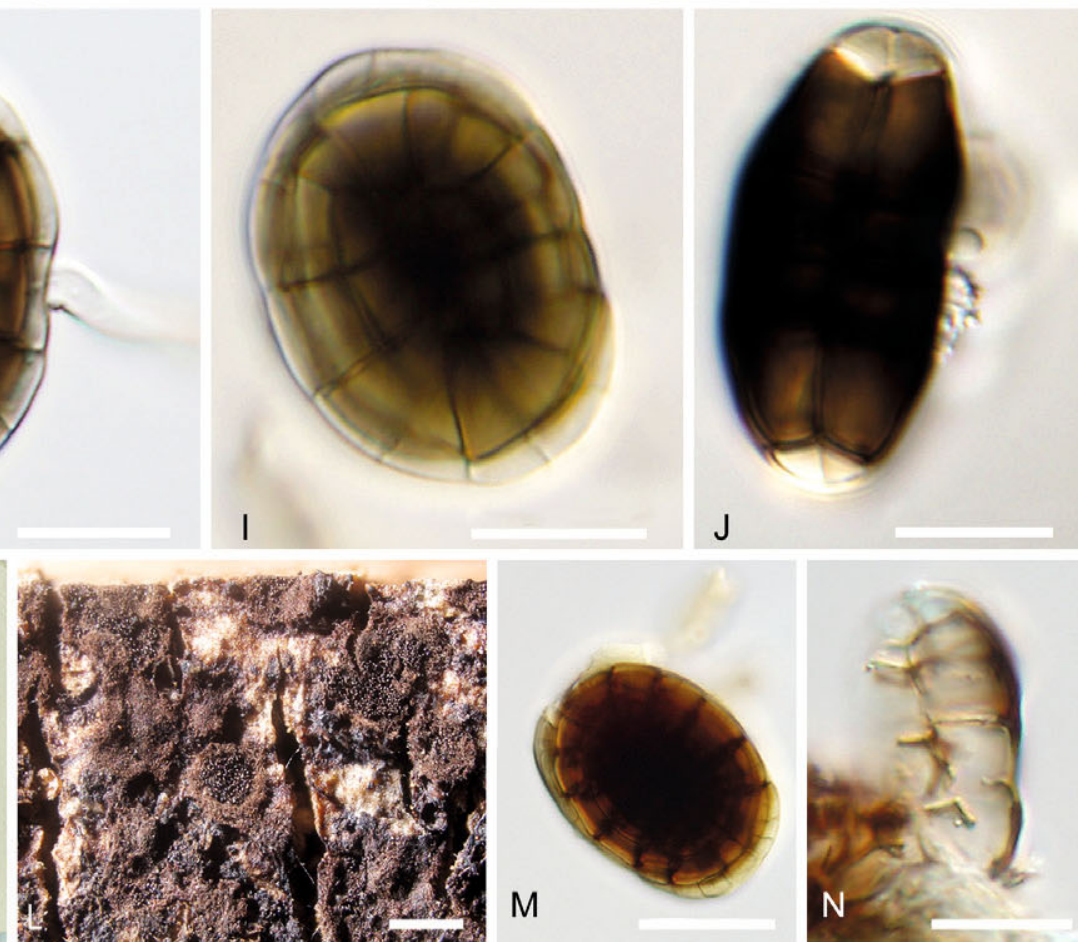

Fig. 11. Hermatomyces tucumanensis (PMA 116083) A. Colonies on the natural substrate. B. Conidiogenous cells, young conidia and subicular hyphae. C. Young cylindrical conidia. D-F. Cylindrical conidia with still attached conidiogenous cell and conidiophore. G-J. Lenticular conidia. K. Envelope and content of the holotype of Scyphostroma mirum (BPI 697801). L. Colonies on the natural substrate. M. Lenticular conidium. N. Fragment of cylindrical conidium. Bar $A=500 \mu \mathrm{m}, B-C=20 \mu \mathrm{m}, D-J=10 \mu \mathrm{m}, \mathrm{L}=500 \mu \mathrm{m}, \mathrm{M}-\mathrm{N}=10 \mu \mathrm{m}$. 
of " $H$. tucumanensis" from dead branches of Averrhoa carambola, Alchornea cordifolia (Euphorbiaceae), Coffea liberica (Rubiaceae), and Elaeidis guineensis (Arecaceae) from Ghana and Sierra Leone. His species concept, based on examination of the type material from Argentina along with material in $\mathrm{K}(\mathrm{M})-\mathrm{IMI}$, was much broader than that of Spegazzini's. Hughes (1953) depicted one specimen with 2-3-celled cylindrical conidia in one column and another morphologically different specimen with six-celled cylindrical conidia in two columns, both with apical pigmentation. In our opinion the specimens studied and illustrated by Hughes (fig. 43) belong to at least two different species, but not to $H$. tucumanensis. Further records are also questionable in the absence of morphological details. Mercado (1984) examined a specimen on the dead trunk of an unidentified tree in Cuba and described only lenticular conidia, but the picture also shows cylindrical conidia with $2-5$ darker apical cells resembling $H$. amphisporus. Similarly, another collection from Cuba and revised in our study (PRM 842348) turned out to belong to $H$. sphaericus (Fig. 10). Matsushima (1993) reported " $H$. tucumanensis" from decaying petioles of a palm tree and a twig of a broad-leaved tree in Peru with 4-6-celled cylindrical conidia composed of globose, hyaline cells. His specimen is obviously not conspecific with $H$. tucumanensis and he most probably referred to a distinct, yet undescribed species of Hermatomyces. Delgado (2013) reported a specimen on rachides of dead leaves of Acoelorrhaphe wrightii (Arecaceae) in Florida without depicting cylindrical conidia. Unpublished morphological data along with unedited pictures were revised within the scope of this study and the Florida specimen seems to represent $H$. amphisporus. Prasher \& Singh (2015) recorded a collection under the name " $H$. tucumanensis" from a branch in litter and bark of Mangifera indica (Anacardiaceae) in India. They mentioned "elliptical to almost round", smooth lenticular conidia 30-40 $\times 20-28 \mu \mathrm{m}$ long and $13.5-15 \mu \mathrm{m}$ thick. Cylindrical conidia were not described and the lenticular conidia in Fig. $1 \mathrm{C}$ match well those of $H$. reticulatus, particularly by the presence of a distinct constriction between halves, comparable dimensions and apparently verruculose wall ornamentation. Chang (1995) recorded a specimen on unknown decaying twigs from a stream in Taiwan having cylindrical conidia with two columns of 3-4 cells each and darkly pigmented apical cells which based on pigmentation and conidial shape does not seem to be conspecific with $H$. tucumanensis either. Finally, Castañeda \& Heredia (2000) and Prasher \& Sushma (2014) considered $H$. tucumanensis monomorphic following Ellis (1971) who described cylindrical conidia as 'setae'. Therefore, the currently known distribution of $H$. tucumanensis must be considered with caution and based on our revision is limited to the Neotropics.

We were unable as a part of this study to re-examine the type material of this species in LPS, which comprises two packets, both of them from one of the two original hosts. One of these collections appears to require selection as a lectotype, for which a sequenced epitype could then be designated. However, we prefer to leave this pending for a future note as we consider it unwise to make a choice without a critical examination of the Spegazzini material.
Material examined: Panama: Chiriquí Province: David, UNACHI, Botanical Garden, along San Cristobal river, $8^{\circ} 26^{\prime} 3.49^{\prime \prime} \mathrm{N}$ $82^{\circ} 27^{\prime} 8.802$ "W, $45 \mathrm{~m}$ a.s.l., on dry rotten twig of unknown tree, 19 Jul. 2017, O. Koukol KZP443 (UCH; CCF 5912- living culture); ibid. on dry rotten hanging twig of Guazuma ulmifolia, 19 Jul. 2017, O. Koukol KZP444 (PMA 116083; CCF 5913- living culture); ibid., on dry rotten hanging twig of unknown tree, 19 Jul. 2017, O. Koukol KZP453 (PRM 946202; CCF 5915- living culture).

\section{Hermatomyces verrucosus Koukol \& G. Delgado, sp. nov.}

MycoBank MB824249

(Figs 12, 15B, D, F, H, 17D)

Etymology: verrucosus, referring to the verrucose surface of the lenticular conidia.

Diagnosis: Differs from other species of Hermatomyces with one conidium type in having distinctly verrucose lenticular conidia and subicular hyphae.

Type: Panama: Chiriquí Province: David, UNACHI, Botanical Garden, along San Cristobal river, $8^{\circ} 26^{\prime} 3.49$ 'N, $82^{\circ} 27^{\prime} 8.802$ 'W, $45 \mathrm{~m}$ a.s.I., on dry rotten stem of unknown liana, 11 Jul. 2017, L. Janošík KZP377 (PMA 116084 holotype; CCF 5903 - ex-type living culture).

Description: Colonies on the natural substrate forming sporodochial, subiculate conidiomata, superficial, more or less circular or oval, scattered or crowded and confluent, brown-black, consisting of a velvety, annular, compact, dark brown, sterile mycelial outer zone enclosing a black, glistening sporulating centre, circular, oval or lobed by confluence, where conidia are easily liberated when touched, 250-700 $\mu \mathrm{m}$ diam when solitary, up to $1500 \mu \mathrm{m}$ long when confluent. Mycelium superficial composed of compact network of repent, branched, septate, smooth or verruculose, pale brown to brown hyphae, 2-4 $\mu \mathrm{m}$ wide; subicular hyphae septate, branched, flexuous, undulate or irregularly geniculate once or few times, pale brown to brown, finely verruculose or finely spinulose to verruculose or locally verrucose, branching and anastomosing to form a dense network. Conidiophores micronematous, mononematous, cylindrical or slightly subulate, subhyaline to pale brown, smooth or finely verruculose, $6-10 \times 2-4 \mu \mathrm{m}$, often corresponding to conidiogenous cells. Conidiogenous cells monoblastic, integrated, terminal, determinate, often arising directly on the superficial mycelium and closely packed together at the fertile centre, sphaerical, subsphaerical or ampulliform, pale brown to brown, smooth or finely verruculose, $4-8 \times 2-5 \mu \mathrm{m}$. Conidia of one type, lenticular, globose, subglobose or disc-shaped in front view, sometimes somewhat irregular, solitary, dry, muriform, constricted at the septa or not, verrucose, central cells brown to dark brown or blackish brown to black, peripheral cells pale brown to brown, wide but sometimes narrow, broadly ellipsoidal to oblong in side view where two distinct adpressed halves can be recognized, each half seen laterally as a row of 4-7 cells, end cells subhyaline to pale brown, middle cells brown to blackish brown, 23-30(-39) $\times$ 21-29.5 $\mu \mathrm{m}, 14-22 \mu \mathrm{m}$ thick, L/W = 1.12. Sexual morph unknown. 

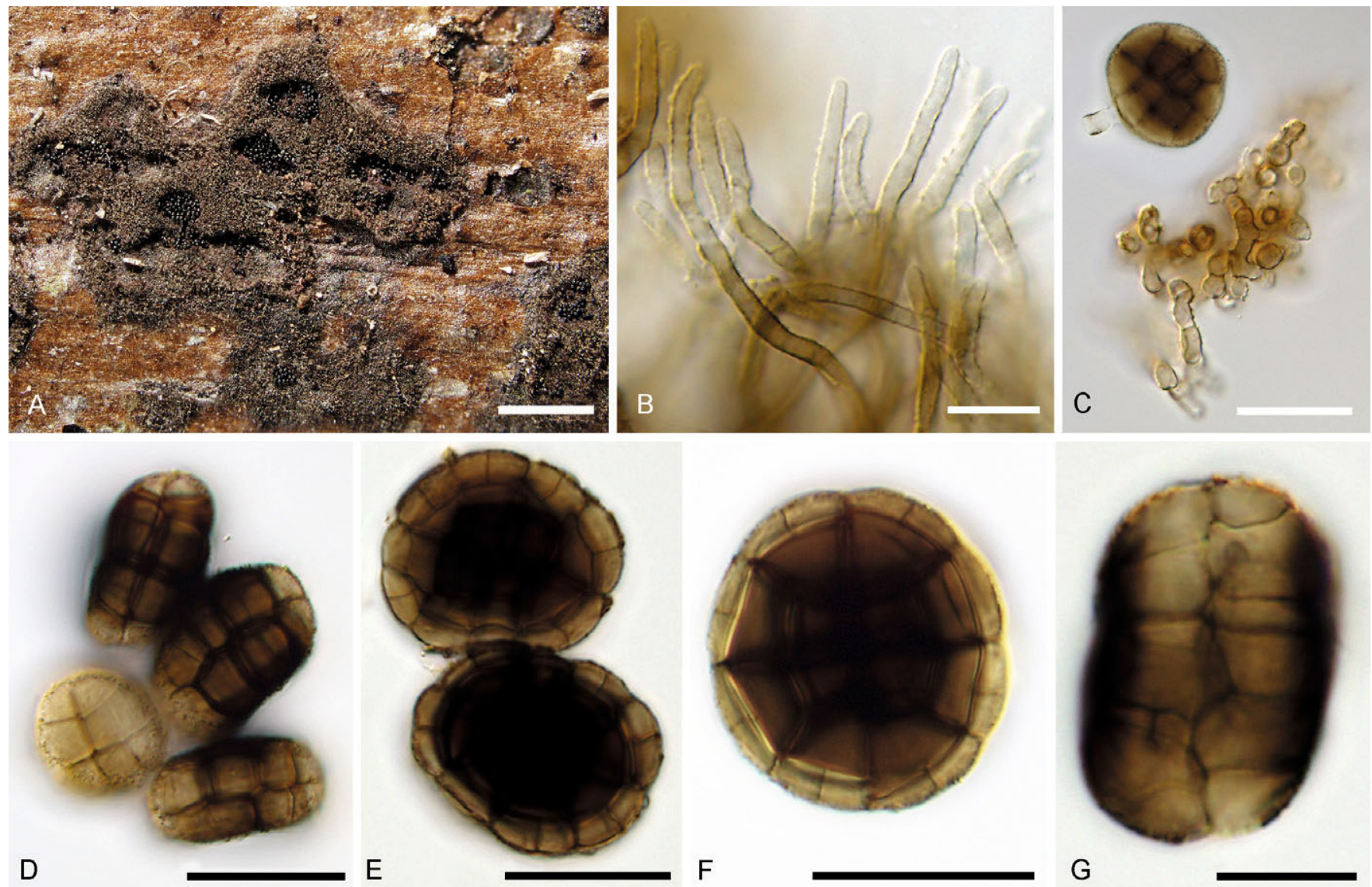

Fig. 12. Hermatomyces verrucosus (PMA 116084 - holotype) A. Colonies on the natural substrate. B. Subicular hyphae. C. Basal hyphae with young conidium. D-G. Mature conidia. Bar $A=500 \mu \mathrm{m}, \mathrm{B}-\mathrm{E}=10 \mu \mathrm{m}, \mathrm{F}=20 \mu \mathrm{m}, \mathrm{G}=10 \mu \mathrm{m}$.

Cultures (Fig. 3V-X): Colonies moderately slow growing reaching on MEA 12-13 $\mathrm{mm}$ diam, on PCA $12 \mathrm{~mm}$, and on PDA $13-15 \mathrm{~mm}$ after $7 \mathrm{~d}$ at $25^{\circ} \mathrm{C}$. No sporulation observed after $4 \mathrm{~m}$ at $25^{\circ} \mathrm{C}$.

Notes: Hermatomyces verrucosus is morphologically close to $H$. sphaericus and $H$. sphaericoides, both with similarly shaped conidia and ornamented walls. Its conidia, however, are distinctly verrucose and wall ornamentation is more conspicuous on the wider ring of paler peripheral cells when seen in front view. Subicular hyphae are distinctly verruculose including sometimes a finely spinulose or locally verrucose ornamentation and less geniculate, more undulate or flexuous in appearance. Moreover, $H$. verrucosus formed a separate clade with high support in all phylogenies distant from these other two monomorphic taxa (Fig. 1) despite the morphological similarities between them.

Additional material examined: Panama: Chiriquí Province: Boquete, Bajo Mono, pipe line trail, $8^{\circ} 49^{\prime} 40.22^{\prime \prime} \mathrm{N} 82^{\circ} 29^{\prime} 26.11^{\prime \prime} \mathrm{W}, 1720 \mathrm{~m}$ a.s.I., on dry rotten twig of unknown tree, 9 Jul. 2017, O. Koukol KZP506 (PRC 4101); David, UNACHI, Botanical Garden, along San Cristobal river, $8^{\circ} 26^{\prime} 3.49^{\prime \prime} \mathrm{N} 82^{\circ} 27^{\prime} 8.802^{\prime \prime} \mathrm{W}, 45 \mathrm{~m}$ a.s.l., on twigs in the litter of unknown tree, 6 Jul. 2016, O. Koukol KZP171 (PRM 946203; CCF 5892 - living culture).

\section{Overview of other Hermatomyces species}

Hermatomyces amphisporus R.F. Castañeda \& Heredia, Cryptog. Mycol. 21: 223 (2000). (Fig. 16A)

Notes: Castañeda \& Heredia (2000) described this species with two conidum types on a decaying branch of Cyathea sp. and on setae of an undetermined fungus from Mexico. The cylindrical conidia are distinct in being turbinate to pyriform, with four short columns of 6-11 cells usually arising from a single basal cell and widening to a bulbous, leprous and graybrown apex. Hermatomyces pandanicola (Tibpromma et al. 2016), has morphologically similar cylindrical conidia with turbinate, dark brown apical cells and short columns arising from a common basal cell but conidia of both types are smaller than those in $H$. amphisporus. DNA sequence data of $H$. amphisporus are still unavailable. but it is accepted here based on the distinct morphology and unusual habitat. This fungus is also reported from decaying branches in a further locality in Mexico (Martínez et al. 2014) and from Vietnam (Mel'nik et al. 2013). This species might have a wider distribution range if other closely resembling specimens in the literature identified as $\mathrm{H}$. tucumanensis are considered (Mercado 1984, Delgado 2013). 

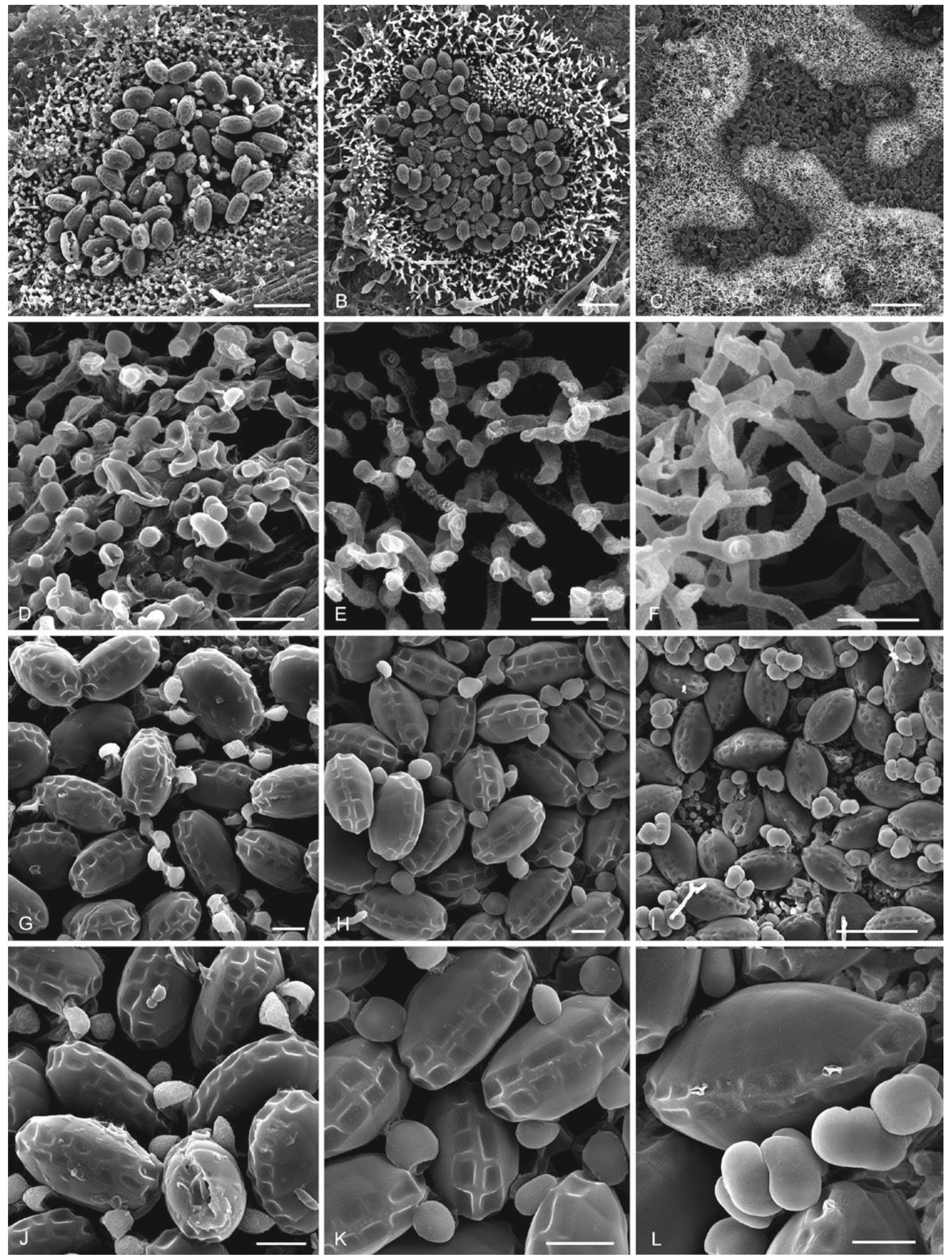

Fig. 13. Hermatomyces species as seen by scanning electron microscope. A, D, G, J. H. bifurcatus (PRM 946196). B, E, H, K. H. constrictus (PRC 4107). C, F, I, L.. H. megasporus (PMA 116077 - holotype). Colony on the substrate, subicular hyphae, conidia, detail of conidia (from top to bottom). Bar $A-B=50 \mu \mathrm{m}, C=200 \mu \mathrm{m}, \mathrm{D}-\mathrm{L}=10 \mu \mathrm{m}$. 

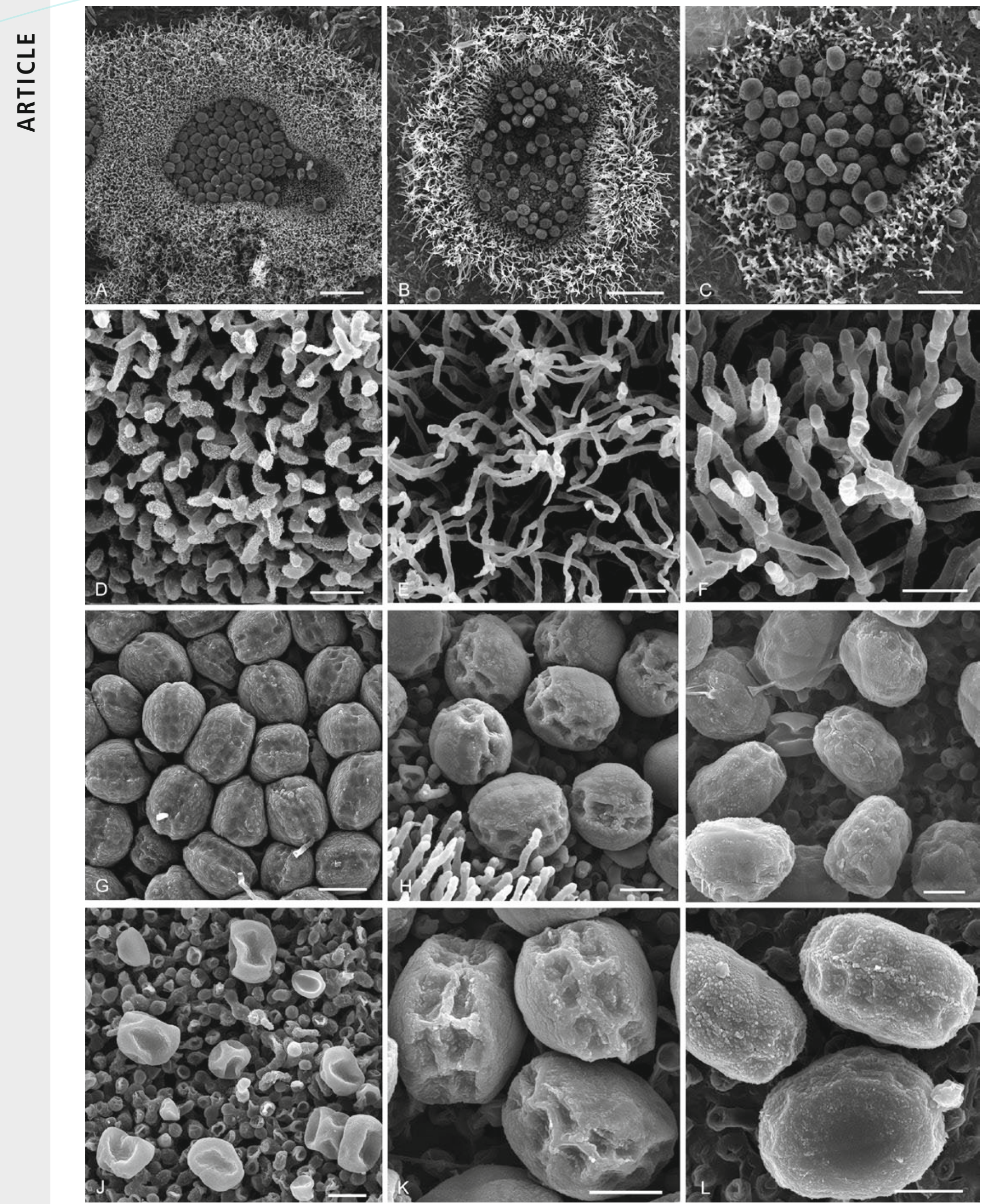

Fig. 14. Hermatomyces species as seen by scanning electron microscope. A, D, G, J. H. reticulatus (PMA 116078). B, E, H, K. H. sphaericoides (PMA 116079 - holotype). C, F, I, L. H. sphaericus (PRC 4106) (from left to right). Colony on the substrate, subicular hyphae, conidia, detail of conidia (from top to bottom). Bar A-B $=50 \mu \mathrm{m}, C=200 \mu \mathrm{m}, \mathrm{D}-\mathrm{L}=10 \mu \mathrm{m}$. 

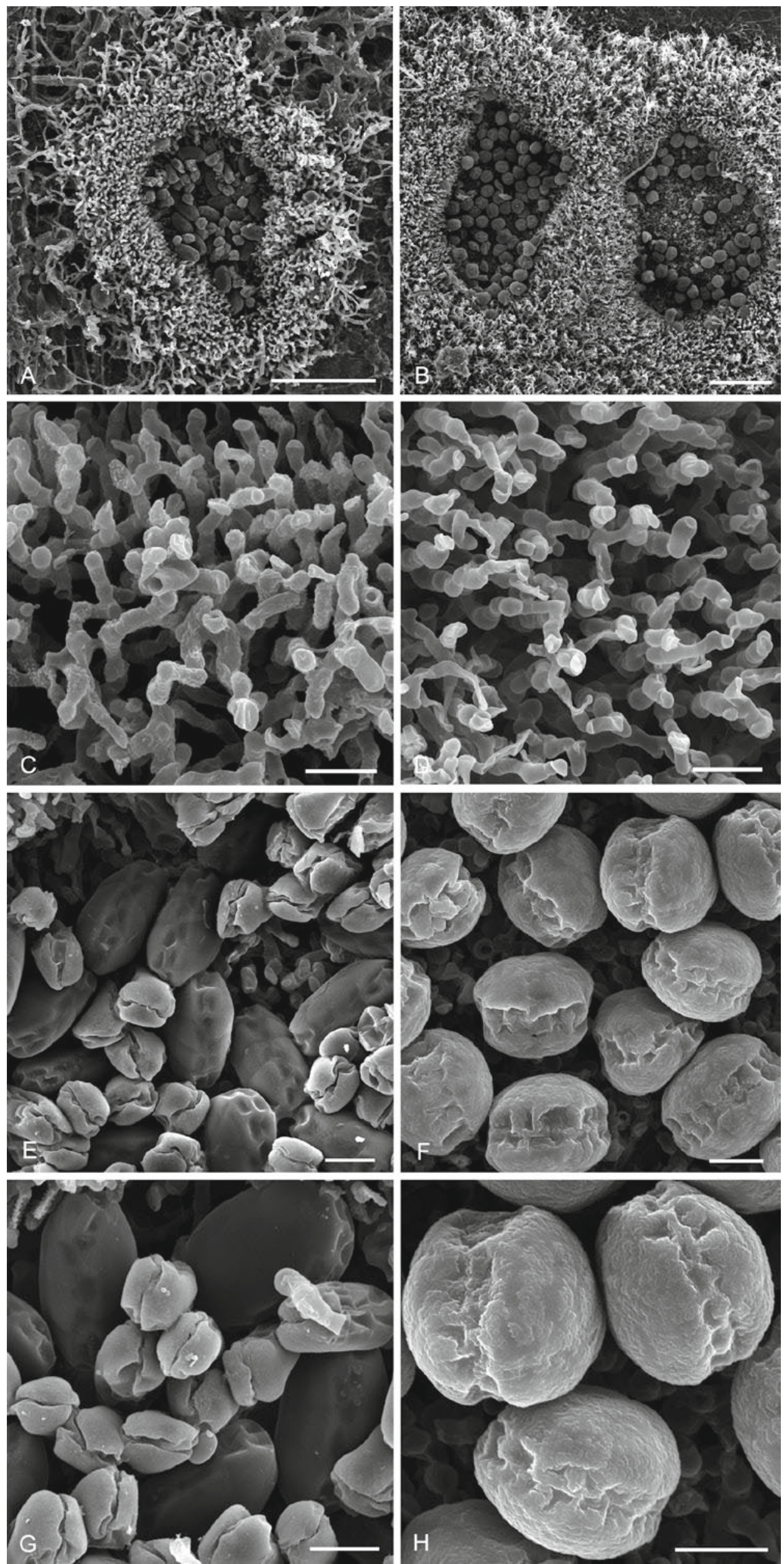

Fig. 15. Hermatomyces species as seen by scanning electron microscope. A, C, E, G. H. tucumanensis (PMA 116083). B, D, F, H. H. verrucosus (PRM 946203) (from left to right). Colony on the substrate, subicular hyphae, conidia, detail of conidia (from top to bottom). Bar A-B $=50 \mu \mathrm{m}$, $C=200 \mu \mathrm{m}, \mathrm{D}-\mathrm{L}=10 \mu \mathrm{m}$. 

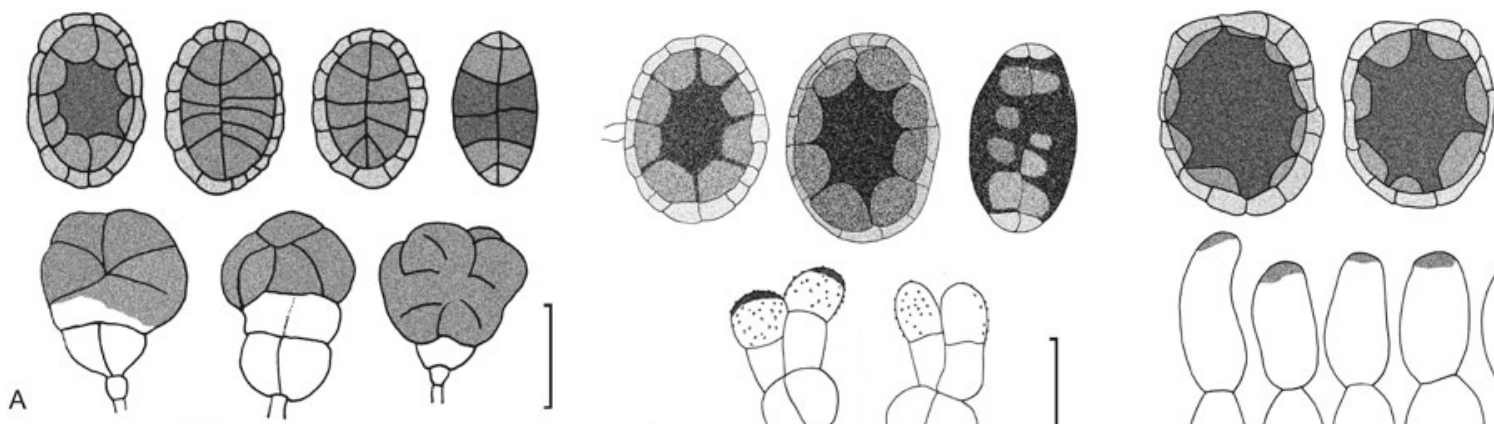

B
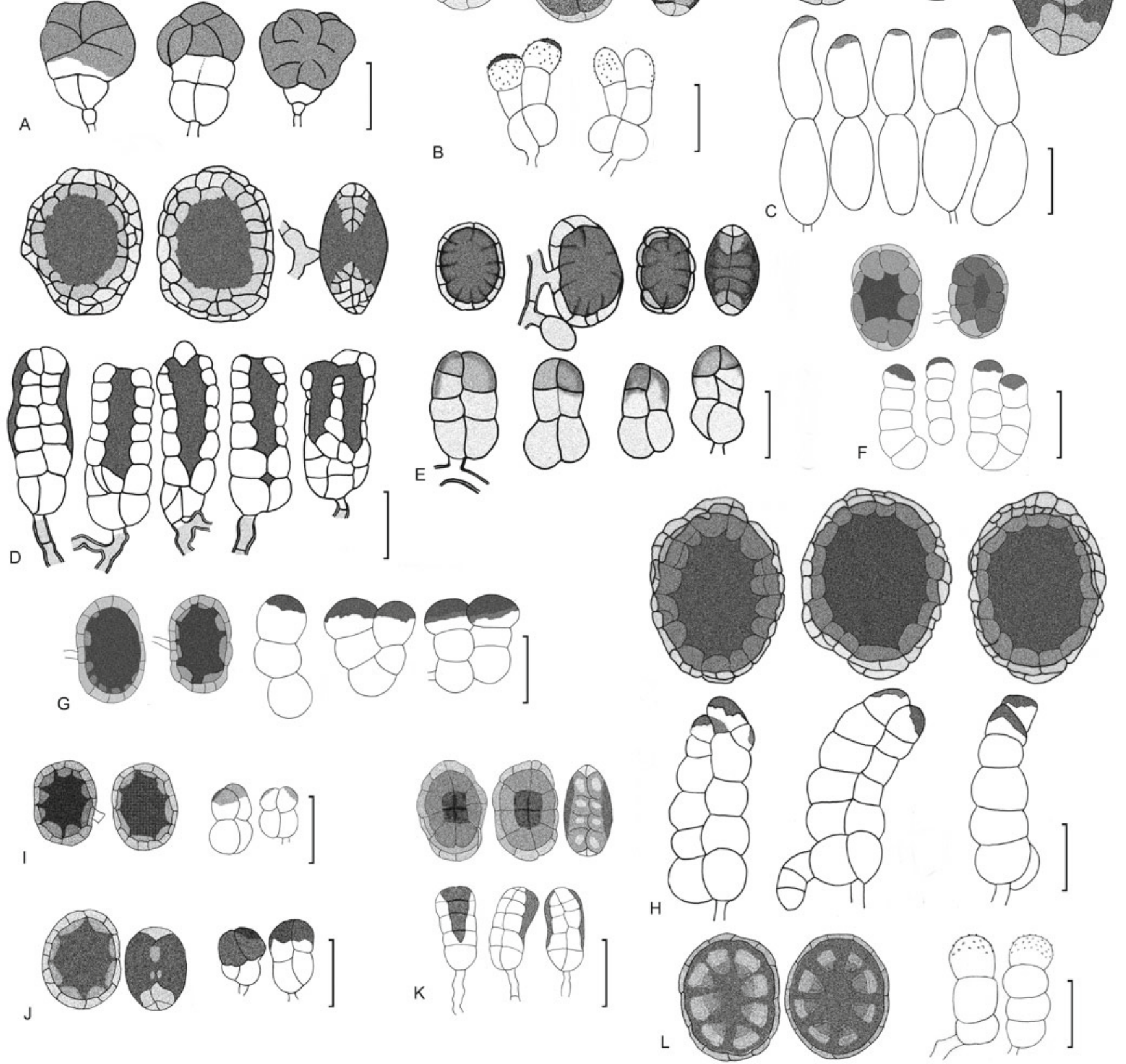

Fig. 16. Species of Hermatomyces with two conidium types, visual guide. A. H. amphisporus. B. H. bifurcatus. C. H. constrictus. D. H. dimorphus. E. H. indicus. F. H. iriomotensis. G. H. krabiensis. H. H. megasporus. I. H. nabanheensis. J. H. pandanicola. K. H. tucumanensis. L. H. uniseriatus. Bar $=20 \mu \mathrm{m}$.

Hermatomyces dimorphus V. Rao \& de Hoog, Stud. Mycol. 28: 35 (1986). (Fig. 16D)

Notes: Rao \& de Hoog (1986) described this species with two condium types from unidentified twigs in Karnataka, India, and so far it is known only from the type locality. The fungus is unique in having the most complex cylindrical conidia among known Hermatomyces species, which were termed 'paraphyses' in the protologue. These condia are composed of four vertical rows of seven cells each with septa in different orientations and a peculiar pigmentation pattern along a central or two columns and extending beyond the middle of the conidia. Although molecular data are not available for $H$. dimorphus, it is accepted here based on the conspicuous morphological features. 
Hermatomyces indicus Prasher \& Sushma, Nova Hedwigia 94: 552 (2014)

Synonym: Hermatomyces thailandicus Doilom et al., Fungal Div. 82: 121 (2016); as "thailandica".

(Fig. 16E)

Notes: Prasher \& Sushma (2014) provided a detailed description of $H$. indicus, which has both condium types, based on a specimen collected on a dead petiole of Phoenix rupicola (Arecaceae) in India and referred to the cylindrical type as 'turbinate' conidia. Doilom et al. (2016) ignored the morphologically close $H$. indicus when introducing $H$. thailandicus, probably due to the absence of molecular data available for this species. They differentiated $H$. thailandicus from another taxon, $H$. tectonae, based on polymorphic nucleotide comparisons, size of conidiophores, and both types of conidia, together with colony features. However, the dimensions, shape and apical pigmentation of the cylindrical conidia, as well as the dimensions of the lenticular conidia of $H$. thailandicus, completely overlap with those of $H$. indicus. Moreover, the only apparent difference inferred from Table 4 in Doilom et al. (2016) is the number of cells in the cylindrical conidia, probably arising from a misunderstanding of the description in Prasher \& Sushma (2014) where the total number of cells is given. Therefore, $H$. thailandicus is considered conspecific with $H$. indicus and reduced to synonymy.

Hermatomyces iriomotensis A. Hashim. \& Kaz. Tanaka, Persoonia 39: 58 (2017).

(Fig. 16F)

Notes: Hashimoto et al. (2017) described H. iriomotensis, with two conidium types, based on a combination of phenotypic and molecular data from dead twigs of a woody plant in Japan. The lenticular conidia with an inconspicuous ring composed of minute peripheral cells and 4-8-celled cylindrical conidia with cells arranged in 1-2 columns represent a unique set of morphological features. Molecular data show a close relationship with another species with both conidium types, $H$. krabiensis (Figs 1-2) but their separation is justified on the basis of the different morphology of their cylindrical conidia.

\section{Hermatomyces krabiensis Tibpromma et al., Phytotaxa 275: 132 (2016).}

(Fig. 16G)

Synonym: Hermatomyces chiangmaiensis J.F. Li et al., Index Fungorum 342: 45 (2017).

Notes: The only available sequence of $H$. chiangmaiensis (LSU rDNA, GenBank KY559394) showed $100 \%$ similarity with that of $H$. krabiensis when an evidently artificial flanking region was trimmed (see also note to $H$. chromolaenae). The two taxa also share an identical habitat, on dead leaves of Pandanus sp. in Thailand, and have similar cylindrical conidia with two columns of 2-3 rectangular to globose cells constricted at the septa and arising from a common basal cell. fig. $29 \mathrm{e}$ of the protologue of $H$. chiangmaiensis (Tibpromma et al. 2017) shows a cylindrical conidium with turbinate, darkened apical cells identical to those of $H$. krabiensis
(Tibpromma et al. 2016). Because no other sequence was available for comparison the differences observed in phenotypic characteristics, such as the smaller lenticular conidia and cylindrical conidia having up to 3-4 columns of cells in the latter, must be considered intraspecific variability. Therefore, $H$. chiangmaiensis is reduced here to synonymy based on morphological and molecular evidence.

Hermatomyces mirum (Starbäck) C.G. Lin et al., Fungal Div. 80: 69 (2016).

Basionym: Scyphostroma mirum Starbäck, Bih. K. svenska VetenskAkad. Handl., Afd. 3 25: 24 (1899).

Type: Brazil: Rio Grande do Sul: on dead trunk, 4 Jul. 1893, G. O. A. Malme (BPI 697801 - holotype).

Notes: Examination of the holotype of Scyphostroma mirum showed this to be conspecific with $H$. tucumanensis (Fig. $11 \mathrm{~K}-\mathrm{N})$. Lenticular conidia were well preserved and had the same morphology as those of $H$. tucumanensis with measurements close to Spegazzini's at 32-42 × 27.5-32 $\mu \mathrm{m}$. The cylindrical conidia were mostly collapsed or broken, but the characteristic two parallel columns of cells and apical melanization were still evident (Fig.11 N). According to Hyde et al. (2016), the monotypic genus Scyphostroma was "wrongly described in the literature and has never been referred to any taxonomic discourses of the genus complex", which is however not a reason for omitting this name as the earliest validly published name for Hermatomyces. Therefore, the widely used generic name Hermatomyces should be conserved or protected against the older Scyphostroma and the binomial $H$. tucumanensis should be conserved or protected against S. mirum.

Hermatomyces nabanheensis Tibpromma et al., Fungal Div. 87: 39 (2017).

(Fig. 16I)

Notes: Hermatomyces nabanheensis was collected on dead leaves of Pandanus sp. in China (Hyde et al. 2017). Overall, it shows some phenotypic similarity with $H$. pandanicola, which has both conidium types, but is phylogenetically distinct. When sequences of $H$. nabanheensis were included in our dataset, they showed a different placement each time (Fig. 1) and this was most evident in the species tree (Fig. 2). Based on morphological and molecular evidence this is accepted as a distinct species.

Hermatomyces pandanicola Tibpromma et al., Phytotaxa 275: 134 (2016).

(Fig. 16J)

Notes: Sequences of $H$. pandanicola did not show a stable phylogenetic placement in our analyses. Based on both nuclear ribosomal DNA regions and the RPB2 gene, the species was placed inside the $H$. sphaericus clade but together they formed a clade separate from these sequences in the EF1- $\alpha$ phylogeny. Considering that this species possesses the two types of conidia but clustered with $H$. sphaericus which has a single type, it could perhaps be a 
hybrid species or the sequences of ITS, LSU nrDNA and RPB2 deposited in GenBank by Tibpromma et al. (2016) do not belong to this taxon. Additional collections are needed to confirm its position and status.

\section{Hermatomyces tectonae Doilom et al., Fungal Div.} 82: 119 (2016).

Notes: In our opinion, $H$. tectonae should be considered of uncertain application because its description is ambiguous, being based on a mixture of $H$. sphaericus and $H$. indicus. The protologue (Doilom et al. 2016: 16) mentions two conidium types, but in our phylogenies the sequences of $H$. tectonae from the holotype and paratype specimens consistently clustered with sequences of $H$. sphaericus with a single conidium type. Moreover, Doilom et al. (2016: Fig. 6) depicts two different types of lenticular conidia; Fig. 6D shows globose or subglobose conidia not flattened in lateral view, while Figs $6 \mathrm{G}-\mathrm{J}$ show oval, distinctly flattened, ellipsoidal or broadly ellipsoidal conidia mixed with cylindrical conidia similar to those of $H$. indicus. Therefore, $H$. tectonae is synonymized here under $H$. sphaericus. Records of $H$. tectonae in Japan by Hashimoto et al. (2017) must also be attributed to $H$. sphaericus.

Hermatomyces uniseriatus S.M. Leão \& Gusmão, Nova Hedwigia 96: 482 (2013).

(Fig. 16L)

Notes: Leão et al. (2013) described this species from rotten bark collected in Brazil. The cylindrical conidia of $H$. uniseriatus consistently have a single column of 3-4 cells with a verrucose, hyaline to pale brown apical cell lacking distinct, darker pigmentation. Without available molecular data, the phylogenetic placement of this species is currently unknown, but we consider it distinct in the genus based on morphological evidence.
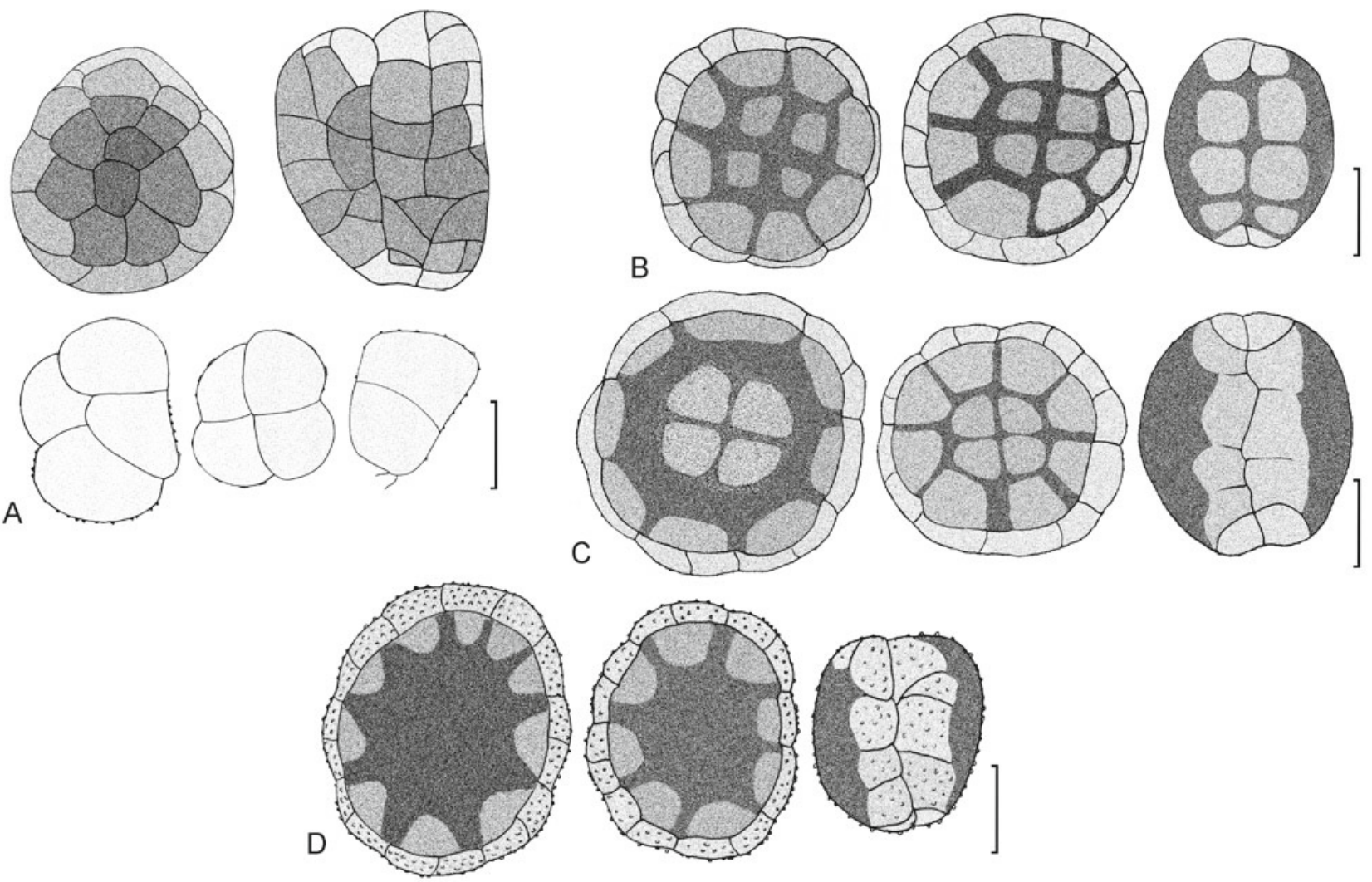

Fig. 17. Species of Hermatomyces with one conidium type, visual guide. A. H. reticulatus. B. H. sphaericoides. C. H. sphaericus. D. $H$. verrucosus. Bar $=20 \mu \mathrm{m}$.

\section{Key to the species of Hermatomyces}

2 (1) Lenticular conidia with transverse, longitudinal and oblique septa, verrucose when young 
3 (2) Conidial ornamentation distinctly verrucose

4 (3) Conidia (15-)19-25 $\mu \mathrm{m}$ thick, $\mathrm{L} / \mathrm{T}=1.26$

H. sphaericoides

Conidia 16-23.5(-28) $\mu \mathrm{m}$ thick, $\mathrm{L} / \mathrm{T}=1.22$

5 (1) Cylindrical conidia two-celled or consisting of cells arranged in one column

6 (5) Cylindrical conidia two-celled, constricted at the septa

H. constrictus

Cylindrical conidia with cells arranged in one column, apical cell verrucose

H. uniseriatus

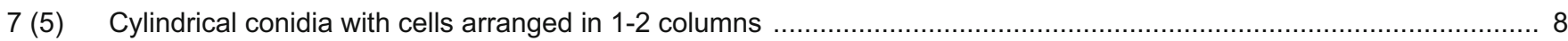

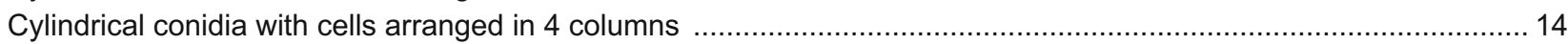

8 (7) ylindrical conidia with apical cells verrucose, subhyaline or pale brown .......................................... H. bifurcatus

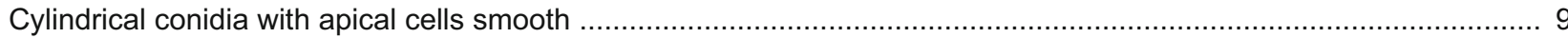

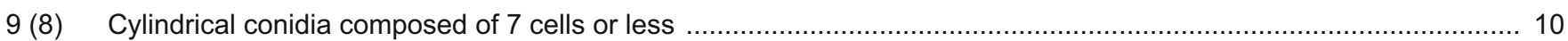

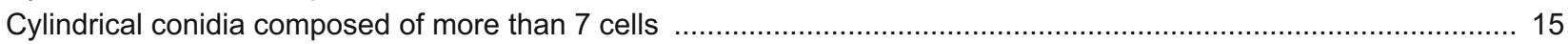

10 (9) Lenticular conidia with peripheral cells constricted at the septa .................................................................

Lenticular conidia with peripheral cells not constricted at the septa .......................................................... 12

11 (10) Lenticular conidia $>30 \mu \mathrm{m}$ in length, cylindrical conidia without swollen lower cells Lenticular conidia 24.5-32.5 $\mu \mathrm{m}$ in length, cylindrical conidia with swollen lower cells

H. iriomotensis

H. krabiensis

12 (10) Cylindrical conidia 9-12 $\mu \mathrm{m}$ wide at the broadest part

H. pandanicola

Cylindrical conidia wider 13

13 (12) Cylindrical conidia 22.5-35.5 $\mu \mathrm{m}$ in length

H. indicus

Cylindrical conidia $15.5-27 \mu \mathrm{m}$ in length

H. nabanheensis

14 (7) Cylindrical conidia 30-38 × 20-26 $\mu \mathrm{m}$, with bulbous, gray-brown apex

H. amphisporus Cylindrical conidia 15-40 × 10-15 $\mathrm{mm}$, with pigmentation in vertical strands between two opposite columns

H. dimorphus

15 (9) Cylindrical conidia with apical cells laterally or apically pigmented brown to blackish brown

H. megasporus

Cylindrical conidia with dark brown pigmentation running from the top downwards and narrowing to a point close to the basal cell(s)

H. tucumanensis

\section{DISCUSSION}

This is the first comprehensive study of Hermatomyces in the Neotropics, based on phenotypic and molecular data of freshly collected specimens from Panama, and also including a revision of selected herbarium specimens. The occurrence of Hermatomyces species in the Neotropics was previously limiteds to the description of three species, including the generic type (Spegazzini 1911, Castañeda \& Heredia 2000, Leão et al. 2013) and scattered records of the common $H$. sphaericus in a few countries (HolubováJechová \& Mercado 1986). The high diversity discovered in Panama and represented by five morphologically and phylogenetically distinct new species is comparable with the one observed in south-east Asia (Hyde et al. 2017). Other previously known taxa, such as $H$. reticulatus, $H$. sphaericus, and $H$. tucumanensis, are reported for the first time from Panama based on complete specimen data. The number of species collected in a single country, eight of the 16 currently recognized taxa, may suggest that this area represents a diversity hot-spot of the genus. Hermatomyces species seem to occur with the same frequency in both the Neotropics and the Palaeotropics, and several species, such as $\mathrm{H}$. indicus and $H$. sphaericus, were shown to have wider distribution areas than previously thought. Collection efforts in neighboring countries targeting these conspicuous hyphomycetes might reveal further novelties in Hermatomyces and expand our understanding of their interspecific relationships.

The phylogenetic placement of $H$. tucumanensis, the generic type, was assessed for the first time using molecular data and based on three representative specimens. Its position supports the monophyly of the genus as a well delimited taxon within Pleosporales (Hashimoto et al. 2017). This is the first time that phylogenetic relationships have been assessed for the most common $H$. sphaericus, the currently available sequences in GenBank (KU999956, 
KX033549, KX033518, KX036229, Y.-R. Ma, unpubl.) are erroneous and belong to a taxon outside Hermatomyces (Delgado et al. 2017). Our phylogenies retrieved from five loci yielded incongruent topologies but the same specimens always clustered together (Fig. 1). Bayesian analysis of the multilocus dataset (Fig. 2) revealed substantial evidence of incomplete lineage sorting in the evolution of Hermatomyces. Less possibly, the incongruent topologies of several species, notably $H$. bifurcatus, $H$. nabanheensis or $H$. pandanicola, indicate hybridization events because sexual morphs of Hermatomyces species have not yet been found.

When Hashimoto et al. (2017) introduced the new family name Hermatomycetaceae, the sporodochial conidiomata and two conidium types were considered the most distinctive family features. The presence of a hyphal subiculum is rare in Pleosporales, and when present is usually restricted to a more or less extensive, sometimes inconspicuous, mycelial growth under the ascomata or conidiomata, or even surrounding them (Zhang et al. 2012, Jaklitsch et al. 2018) but never reaching the degree of organization seen in Hermatomyces.

Colony architecture followed a very similar pattern in all new or previously described taxa despite some obvious differences, which might be useful in species level delimitation especially among taxa with both conidium types. Hermatomyces bifurcatus, for example, produces sporodochia with an inconspicuous subiculum and an almost flattened outer zone (Fig. 4A), while those of $H$. megasporus have a dense and well-developed subiculum of distinct height (Fig. 6A). However, differences in size or colour among specimens of the single conidium type species H. sphaericus (Fig.9A-B) might be mainly due to ecological factors. The morphology of the subicular hyphae, particularly their appearance and wall ornamentation, was also more or less typical of each species, but differences in roughness or degree of geniculation were seen even within the same subiculum; this suggests variation due to age since the more ornamented or geniculate hyphae might be older. In contrast, the bottom of the fertile colony centre is more uniform among the species and is covered with a network of repent and brown hyphae where micronematous or semimacronematous conidiophores arise and are intermixed with subsphaerical or ampulliform conidiogenous cells closely packed together. These conidiogenous cells are apparently most related to the production of lenticular conidia, but both conidium types were found emerging from short conidiophores.

Cultures isolated from Panamanian specimens (Fig. 3) rarely sporulated and conidia were only seen in a very few strains of taxa with a single conidium type, such as $H$. sphaericus (Fig. 9L-O) or $\mathrm{H}$. sphaericoides (Fig. $8 \mathrm{~L}-\mathrm{N}$ ). This is consistent with previously described species which failed to sporulate even after extended incubation periods (Tibpromma et al. 2016, Hashimoto et al. 2017) and seems to be a regular tendency of Hermatomyces isolates. Matsushima (1993) was the only one who reported production of both types of conidia on Corn Meal agar for a putative new species misidentified as $H$. tucumanensis.

In the past, members of the genus have been regularly recorded during mycological surveys carried out in tropical regions, but variability in morphology was often disregarded and collections were frequently identified as $H$. tucumanensis even though cylindrical conidia were not observed. This excessively conservative approach contrasts with the recent inflation in the number of newly described Hermatomyces species and reflects the opposite extreme of non-critical hunt for new species without serious consideration of currently recognized species (Doilom et al. 2016, Tibpromma et al. 2016). Importance given to molecular analyses with improperly edited sequences easily resulted in artifacts and misleading conclusions about phylogenetic affinities and taxonomic novelties. Based on our results, five new species are described, but seven species are synonymized, which is unusual considering that the ratio between the number of species recognized after versus before the study is 0.94 (16 vs. 17) and lower than studies on comparably large genera (Hawksworth \& Lücking 2017). We propose for future studies aimed at Hermatomyces that descriptions of new species based on single specimens or isolates should be made only if distinct morphological characteristics are present (Hashimoto et al. 2017). In the particular case of taxa with one conidium type, reliable identification should be done only by including molecular sequence data. The ITS region seems to be a good barcode for resolution at species level in this genus, but the addition of sequence data from other coding regions is recommended. The use of rather conservative LSU as a sole marker (Tibpromma et al. 2017) should be avoided, as is the widespread use of SSU, and especially in the description of taxonomic novelties due to the extremely low variability of this region.

Our findings of several collections of the same Hermatomyces species from largely unrelated plant species (monocotyledons vs. dicotyledons) indicates that substrate identity has limited taxonomic value in this case and Hermatomyces species are more restricted by the physical condition of the substrate. The most commonly observed substrates in Panama were found to be heavily rotten hanging stems of lianas or twigs of various shrubs and trees while still attached to the tree or hanging also on the lianas. This aerial position allows the substrate to be drier than similar material in litter, which seems to be an important feature in the development of Hermatomyces species. Although such a substrate may be found in various ecosystems, the distribution of Hermatomyces species seems to be limited by elevation and climate. In our study, they were most frequently found in seasonal lowland tropical forest (at 45-100 m a.s.l.; UNACHI Botanical Garden and Los Algarrobos, with six species) and in elevations of about $1700 \mathrm{~m}$ (Boquete, Bajo Mono, with four species) but not above $1900 \mathrm{~m}$ where forests are humid throughout the year and despite numerous surveys performed at such localities. Interestingly, the permanently humid Atlantic site was less rich in both the diversity and frequency of occurrence of the colonies with only two species. Targeted sampling also showed that Hermatomyces colonies may be quite frequent, and virtually every second twig in the seasonal lowland forest at the Pacific site carried them. Sometimes, up to three species co-occurred on the same twig, only several centimetres apart. These results contrast with those of previous studies where Hermatomyces species were found on humid plant material or even on material immersed in water (Chang 1995, Barbosa \& Gusmão 2011). The main pathway of dispersal of Hermatomyces species 


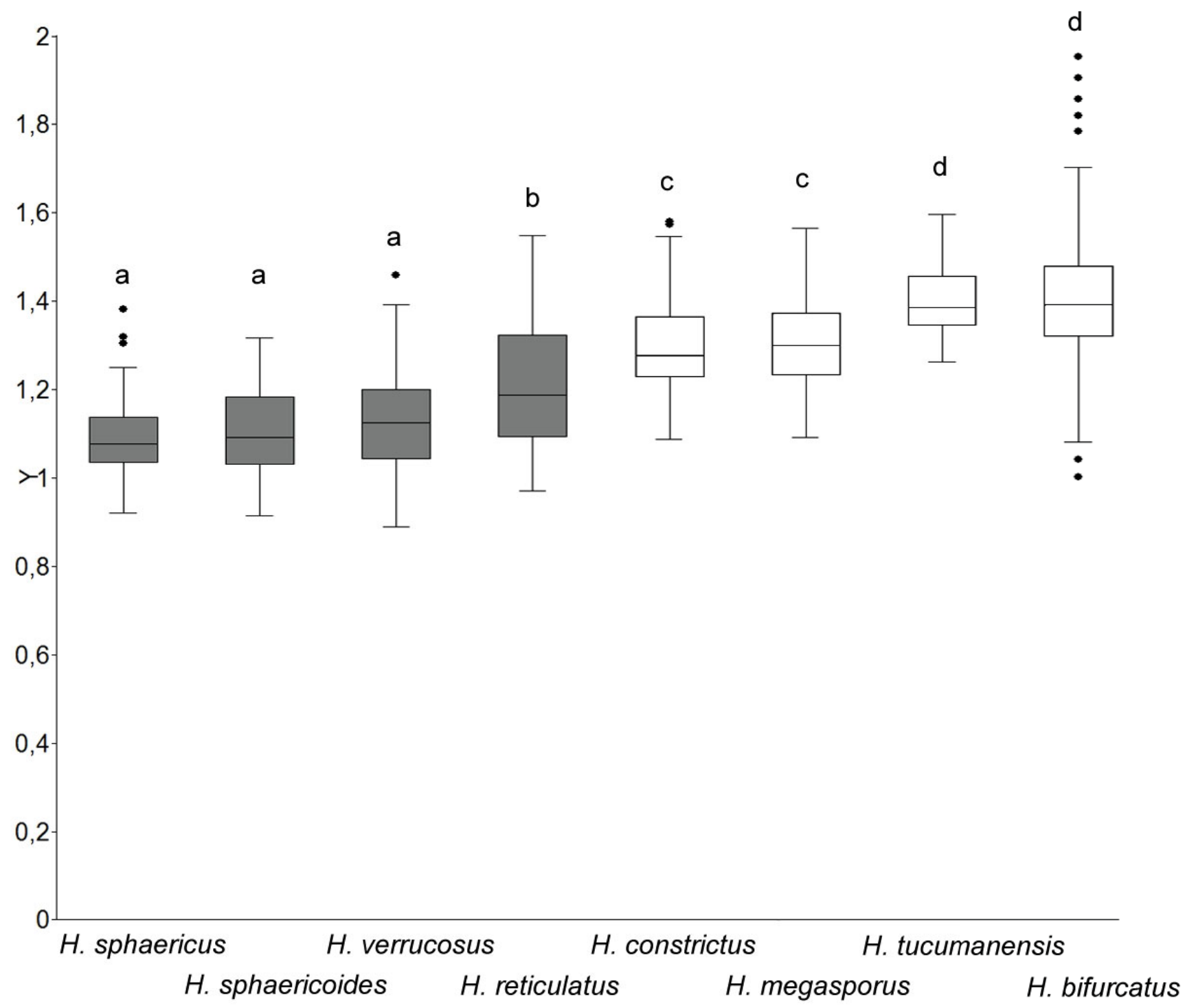

Fig. 18. Mean length/width ratios of lenticular conidia of Hermatomyces species collected in Panama. Species with one conidium type are indicated by gray boxes. Letters above the boxes indicate significant differences $(P<0.05)$ obtained from non-parametric Kruskal-Wallis comparison.

remains questionable. Their large, multicellular conidia do not suggest effective dispersal by wind and the dispersion by raindrops and bark flow seems more probable. The presence of sequence KU977564 originating from an unidentified endophyte isolated from seeds of Apeiba membranacea (Malvaceae) in the $H$. sphaericus clade (Fig. 1) indicates that $H$. sphaericus may have an endophytic phase.

Based on our multiple phylogenies, we did not find any clear pattern in evolution of one and two conidium type Hermatomyces species. The similarity of young lobed conidia of $H$. reticulatus to the cylindrical conidia of $H$. bifurcatus, and that both types of conidia are born as globose, blown ends of the conidiogenous cells, may suggest a potential common origin of these two types of conidium. Intuitively, it might be expected that monomorphic species would be ancestral, but this situation was not apparent in any phylogeny. In most cases (Fig. 1), species with two conidium types are found at the base of the phylogenetic trees. Therefore, we assume that the two-type state is ancestral in Hermatomyces. We also found no evolutionary trend in the complexity of cylindrical conidia, although the morphology of lenticular conidia showed a pattern between the two groups of species. All species with one type have verruculose to verrucose conidia which are almost circular in front view (L/W 1) compared to smooth conidia of broadly ellipsoidal to ellipsoidal conidia of those with two types (L/W > 1.2, Fig. 18). Rao \& de Hoog (1986) assumed that the conidia differed in their ecological roles. The perpendicular position of the cylindrical conidia in the colony suggests they serve as a kind of protection or cushion to the lenticular conidia. Indeed, only the germination of lenticular conidia has been observed (Doilom et al. 2016), and the capacity of cylindrical conidia to germinate has not been proved. Even if cylindrical conidia function only as support to the lenticular conidia and do not contribute to dispersal, we recommend the maintenance of the term conidium in both cases to avoid further confusion. 


\section{ACKNOWLEDGMENTS}

We are grateful to Markéta Šandová (PRM), Shannon Dominick (BPI) and Lee Davis $(\mathrm{K}(\mathrm{M}))$ for the loan of specimens in their care. We also thank Ivana Borovičková for technical assistance in obtaining the molecular data, and Alena Kubátová for preparation of specimens for electron microscopy, as well as Orlando Cáceres, Lukáš Janošík and Petr Zehnálek for assistance in the field. This study was supported by Institutional Support for Science and Research of the Ministry of Education, Youth and Sports of the Czech Republic. G.D. also acknowledges Magzoub Ismail, Michael Manning and Kamash Ramanathan (EMlab P\&K) for provision of laboratory facilities. The Environmental Ministry of Panama (MiAmbiente) is thanked for issuing the collection and export permits (SE/APH-3-15, SE/AP-1716, SEX/H-4-15 \& SEX/H-6-16).

\section{REFERENCES}

Barbosa FR, Gusmão LFP (2011) Conidial fungi from semi-arid Caatinga Biome of Brazil Rare freshwater hyphomycetes and other new records. Mycosphere 2: 475-485.

Becerra Cl, Heredia G, Arias RM (2007) Contribución al conocimiento de los hongos anamorfos saprobios del Estado de Tabasco II. Revista Mexicana de Micologia 24: 39-53.

Bouckaert R, Heled J, Kühnert D, Vaughan T, Wu C-H, et al. (2014) BEAST 2: A Software Platform for Bayesian Evolutionary Analysis. PLoS Computational Biology 10: e1003537.

Castañeda RF, Heredia G (2000) Two new dematiaceous hyphomycetes on Cyathea from Mexico. Cryptogamie, Mycologie 21: 221-228.

Chang HS (1995) Notes on Taiwan dematiaceous hyphomycetes, some species of the genera Exserticlava, Craspedodidymum and Hermatomyces. Botanical Bulletin of Academia Sinica 36: 243-246.

Conceição LB, Marques MFO (2015) A preliminary study on the occurrence of microscopic asexual fungi associated with bird nests in Brazilian semi-arid. Mycosphere 6: 274-279.

Darriba D, Taboada GL, Doallo R, Posada D (2012) jModelTest 2: more models, new heuristics and parallel computing. Nature Methods 9: 772.

Delgado G (2013) South Florida microfungi: a new species of Ellisembia (hyphomycetes) with new records from the U.S.A. Mycotaxon 123: 445-450.

Delgado G, Mena J, Calduch M, Decock C (2002) Hyphomycetes (hongos mitospóricos) del área protegida Mil Cumbres, Cuba occidental. Cryptogamie, Mycologie 23: 277-293.

Delgado G, Koukol O, Cáceres O, Piepenbring M (2017) The phylogenetic placement of Ernakulamia cochinensis within Pleosporales (Dothideomycetes, Ascomycota). Cryptogamie, Mycologie 38: 435-451.

Doilom M, Dissanayake AJ, Wanasinghe DN, Boonmee S, Liu JK, et al. (2016) Microfungi on Tectona grandis (teak) in Northern Thailand. Fungal Diversity 39: 1-76.

Ellis MB (1971) Dematiaceous Hyphomycetes. Kew: Commonwealth Mycological Institute.

Farr ML, Goos RD (1989) Subicularium reticulatum gen. et sp. nov., an unusual fungus from Venezuela. Memoirs of the New York Botanical Garden 49: 66-69.

Farris JS, Källersjö M, Kluge AG, Bult C (1994) Testing significance of incongruence. Cladistics 10: 315-319.

Hammer $\varnothing$, Harper DAT, Ryan PD (2001) PAST: Paleontological Statistics Software Package for Education and Data Analysis. Palaeontologia Electronica 4: 1-9.

Harahap I (2013) Community structure of sporulating fungi on decaying litter of Shorea spp. at Dramaga Research Forest, Bogor. MSc thesis, Bogor Agricultural University, Indonesia [in Indonesian].

Hashimoto A, Matsumura M, Hirayama K, Tanaka K (2017) Revision of Lophiotremataceae (Pleosporales, Dothideomycetes): Aquasubmersaceae, Cryptocoryneaceae, and Hermatomycetaceae fam. nov. Persoonia 39: 51-73.

Hawksworth DL, Lücking R (2017) Fungal diversity revisited: 2.2 to 3.8 million species. Microbiology Spectrum 5: FUNK-0052-2016.

Heredia G, Mena J, Mercado A, Reyes M (1997) Tropical hyphomycetes of Mexico. II. Some species from the Tropical Biology Station “Los Tuxtlas", Veracruz, Mexico. Mycotaxon 64: 203-223.

Heredia G, Mercado A (1998) Tropical hyphomycetes of Mexico. III. Some species from the Calakmul Biosphere Reserve, Campeche. Mycotaxon 68: 137-143.

Holubová-Jechová V, Mercado A (1986) Studies on Hyphomycetes from Cuba IV. Dematiaceous Hyphomycetes from the Province Pinar del Rio. Česká Mykologie 40: 142-164.

Hughes SJ (1953) Fungi from the Gold Coast. II. Mycological Papers 50: $1-104$.

Hyde KD, Hongsanan S, Jeewon R, Bhat DJ, McKenzie EHC, et al. (2016) Fungal diversity notes 367-490: taxonomic and phylogenetic contributions to fungal taxa. Fungal Diversity 80: $1-270$.

Hyde KD, Norphanphoun C, Abreu VP, Bazzicalupo A, Chethana KWT, et al. (2017) Fungal diversity notes 603-708: taxonomic and phylogenetic notes on genera and species. Fungal Diversity 87: 1-235.

Jaklitsch WM, Checa J, Blanco MN, Olariaga I, Tello S, et al. (2018) A preliminary account of the Cucurbitariaceae. Studies in Mycology 90: 71-118.

Leão SM, Gusmão LFP, Castañeda RF (2013) Conidial fungi from the semi-arid Caatinga biome of Brazil. Three new species and new records. Nova Hedwigia 96: 479-494.

Liu JK, Hyde KD, Jeewon R, Phillips AJL, et al. (2017) Ranking higher taxa using divergence times: a case study in Dothideomycetes. Fungal Diversity 84: 75-99.

Liu YJ, Whelen S, Hall B D (1999) Phylogenetic relationships among ascomycetes: evidence from an RNA polymerse II subunit. Molecular Biology and Evolution 16: 1799-1808.

Martínez K, Heredia G, Rosique E, Cappello S (2014) Hongos anamorfos asociados a restos vegetales del Parque Estatal "Agua Blanca", Macuspana, Tabasco, México. Acta Botánica Mexicana 107: 99-119.

Matsushima T (1993) Matsushima Mycological Memoirs 7: 1-75.

Mel'nik VA (2000) Definitorium fungorum Rossiae Classis Hyphomycetes. Fasc. 1. Fam. Dematiaceae. St Petersburg: Nauka.

Mel'nik VA, Novozhilov YK, Popov ES, Alexandrova AV, Kovalenko AE (2013) Anamorphic fungi of Vietnam III (in Russian). Mikologiya i Fitopatologiya 47: 316-320.

Mercado A (1984) Hifomicetes Demaciáceos de Sierra del Rosario, Cuba. Havana: Editorial Academia.

Mercado A, Delgado G, Mena J, Guarro J (2002) Some hyphomycetes (mitosporic fungi) from "Ciénaga de Zapata" Biosphere Reserve (Cuba). Boletín de la Sociedad Micológica de Madrid 26: 183- 
188.

O'Donnell K (1993) Fusarium and its near relatives. In: The Fungal Holomorph: mitotic, meiotic and pleomorphic speciation in fungal systematics (Reynolds DR \& Taylor JW, eds): 225-233. Wallingford: $C A B$ International.

O'Donnell K, Cigelnik E (1997) Two divergent intragenomic rDNA ITS2 types within a monophyletic lineage of the fungus Fusarium are nonorthologous. Molecular Phylogenetics and Evolution 7: 103-116.

Piepenbring M (2006) Checklist of fungi in Panama. Puente Biologico 1: 1-190.

Piepenbring M (2007) Inventoring the fungi of Panama. Biodiversity and Conservation 16: 73-84.

Prasher IB, Singh G (2015) New and interesting Hyphomycetes from North-Western Himalayas. Kavaka 44: 83-86.

Prasher IB, Sushma (2014) Hermatomyces indicus sp. nov. (Hyphomycetes) from India. Nova Hedwigia 99: 551-556.

Pratibha J, Raghukumar S, Bhat DJ (2012) Diversity of litter degrading microfungi from the forests of Western Ghats, India. In: Biodiversity and Taxonomy (Kumar AB, Nayar MP, Varma RV, Peethambaran CK, eds): 195-210. Delhi: Narendra Publishing House.

Rambaut A, Drummond AJ (2009) Tracer. Version 1.5. Available from: http://beast.bio.ed.ac.uk

Rao V, Hoog GS de (1986) New or critical hyphomycetes from India. Studies in Mycology 28: 1-84.

Rehner SA, Buckley E (2005) A Beauveria phylogeny inferred from nuclear ITS and EF1-alpha sequences: evidence for cryptic diversification and links to Cordyceps teleomorphs. Mycologia 97: 84-98.

Ronquist F, Teslenko M, Van der Mark P, Ayres DL, Darling A, et al. (2012) MrBayes 3.2: Efficient Bayesian phylogenetic inference and model choice across a large model space. Systematic Biology 61: 539-542.
Spegazzini C (1911) Mycetes Argentinenses. Series V. Anales del Museo Nacional de Buenos Aires Series 3: 329-467.

Stamatakis A, Hoover P, Rougemont J (2008) A rapid bootstrap algorithm for the RAxML web-servers. Systematic Biology 75: 758-771.

Starbäck K (1899) Ascomyceten der ersten Regnell'schen Expedition. I. Bihang till Kongl. Svenska Vetenskaps-akademiens Handlingar 25: 1-68.

Swofford DL (2002) PAUP*: phylogenetic analysis using parsimony ( ${ }^{*}$ and other methods). Version 40b10. Sunderland, MA: Sinauer Associates.

Taylor J, Hyde KD (2003) Microfungi of Tropical and Temperate Palms. [Fungal Diversity Research Series no. 12.] Hong Kong: Fungal Diversity Press.

Tibpromma S, Bhat JD, Doilom M, Lumyong S, Nontachaiyapoom S, et al. (2016) Three new Hermatomyces species (Lophiotremataceae) on Pandanus odorifer from Southern Thailand. Phytotaxa 275: 127-139.

Tibpromma S, Hyde KD, Jeewon R, Maharachchikumbura SSN, Liu J-K, et al. (2017) Fungal diversity notes 491-602: taxonomic and phylogenetic contributions to fungal taxa. Fungal Diversity $\mathbf{8 3}$ : $1-261$.

White TJ, Bruns T, Lee S, Taylor J (1990) Amplification and direct sequencing of fungal ribosomal RNA genes for phylogenetics. In: PCR Protocols: a guide to methods and applications (Innis MA, Gelfand DH, Sninsky JJ, White TJ, eds): 315-322. San Diego: Academic Press.

Zhang T, Zhao G, Zhang X, Liu H, Wu Y (2009) 26 Genera of Dematiaceous Dictyosporous Hyphomycetes excluding Alternaria. [Flora Fungorum Sinicorum no. 31.] Beijing: Science Press.

Zhang Y, Crous PW, Schoch CL, Hyde KD (2012) Pleosporales. Fungal Diversity 53: 1-221. 